University of Louisville

ThinkIR: The University of Louisville's Institutional Repository

$12-2014$

\title{
Earthworm, microbial biomass, and leaf litter decay responses after invasive honeysuckle shrub removal from urban woodlands.
}

Robert Preston Pipal

University of Louisville

Follow this and additional works at: https://ir.library.louisville.edu/etd

Part of the Biodiversity Commons, Biology Commons, and the Zoology Commons

\section{Recommended Citation}

Pipal, Robert Preston, "Earthworm, microbial biomass, and leaf litter decay responses after invasive honeysuckle shrub removal from urban woodlands." (2014). Electronic Theses and Dissertations. Paper 1759.

https://doi.org/10.18297/etd/1759

This Doctoral Dissertation is brought to you for free and open access by ThinkIR: The University of Louisville's Institutional Repository. It has been accepted for inclusion in Electronic Theses and Dissertations by an authorized administrator of ThinkIR: The University of Louisville's Institutional Repository. This title appears here courtesy of the author, who has retained all other copyrights. For more information, please contact thinkir@louisville.edu. 
EARTHWORM, MICROBIAL BIOMASS, AND LEAF LITTER DECAY RESPONSES

AFTER INVASIVE HONEYSUCKLE SHRUB REMOVAL FROM URBAN

WOODLANDS

\author{
By \\ Robert Preston Pipal \\ B.S., University of Louisville, 2007 \\ A Dissertation \\ Submitted to the Faculty of the \\ College of Arts and Sciences of the University of Louisville \\ in Partial Fulfillment of the Requirements \\ for the Degree of
}

Doctor of Philosophy

Department of Biology

University of Louisville

Louisville, Kentucky

December 2014 
Copyright 2014 by Robert Preston Pipal

All rights reserved 

EARTHWORM, MICROBIAL BIOMASS, AND LEAF LITTER DECAY RESPONSES

AFTER INVASIVE HONEYSUCKLE SHRUB REMOVAL FROM URBAN

WOODLANDS

\author{
By \\ Robert Preston Pipal \\ B.S., University of Louisville, 2007 \\ A Dissertation Approved on
}

November 17, 2014

by the following Dissertation Committee

Dr. Margaret Carreiro

Dr. Michael Weintraub

Dr. Susanna Remold

Dr. Sarah Emery

Dr. Perri Eason 


\section{DEDICATION}

This dissertation is dedicated to my mother, Judith Ann Pipal. It is from her that I developed my love of science and nature. Her encouragement, support, and constant love sustained me through this project. 


\section{ACKOWLEDGEMENTS}

There are many individuals who contributed their time, labor, and scholarly input to make this dissertation a success. First, I would like to thank my mentor and advisor, Margaret M. Carreiro. Without her insights, encouragement, and financial support, this dissertation would not have been possible. I would also like to thank Mike Weintraub, Sarah Emery, Perri Eason, and Susanna Remold for serving on my dissertation committee, guiding my research, and contributing their professional input and advice. I would especially like to thank Mike Weintraub for allowing me the opportunity to use his lab for my soil nutrient and microbial biomass study and for providing funding for my research. Many people also assisted in field work, laboratory processing, and the analyses presented in this dissertation. Leaf litter chemistry data were completed by Richard Schultz of the University of Louisville Environmental Analysis Laboratory. Earthworm species identifications were verified by the Natural Resources Research Institute at the University of Minnesota. Microbial biomass C and $\mathrm{N}$ data were analyzed by members of Mike Weintraub's lab at the University of Toledo's Ecosystem and Soil Ecology Laboratory. I would also like to thank Julie Deignan, Gavin Bradley, and Wesley Reichle for their invaluable field and laboratory assistance throughout this project. Special thanks to the Louisville Olmsted Park Conservancy, particularly Major Waltman and Robert Woodford, for logistical support. Funding for this project was provided by the Kentucky Society of Natural History (Woody Boebinger Memorial Scholarship student research grant), an Environmental Protection Agency funded grant to the Louisville Olmsted Park Conservancy, and Dr. Margaret Carreiro. 


\section{ABSTRACT \\ EARTHWORM, MICROBIAL BIOMASS, AND LEAF LITTER DECAY RESPONSES AFTER INVASIVE HONEYSUCKLE SHRUB REMOVAL FROM URBAN WOODLANDS}

\section{Robert Preston Pipal}

November 17, 2014

Invasive species are one of the leading causes of biodiversity loss and their presence can significantly impact the structure and function of native ecosystems. In this dissertation, the impacts of the invasive honeysuckle shrub, Lonicera maackii, on exotic earthworm populations, leaf litter decay responses, and inorganic and organic nutrient pools in an urban woodland park are assessed. Chapter 1 provides a brief review of honeysuckle's effects on forest ecosystems. Chapter 2 describes honeysuckle's effects on exotic earthworm populations and the seasonal importance of macroinvertebrates to leaf litter decomposition in urban woodlands. This study revealed that $L$. maackii promoted higher exotic earthworm biomass and density and that macroinvertebrates actively decomposed litter across all seasons. In Chapter 3, the effect of macroinvertebrate activity (including earthworms) on the decomposition and nitrogen dynamics of honeysuckle and sugar maple leaf litter mixtures during the late winter were assessed to determine if they contribute to honeysuckle success. Without macroinvertebrates, litter mixtures imported nitrogen in late winter, reducing nitrogen availability to plants. With macroinvertebrates, nitrogen release coincided with honeysuckle leaf expansion in late 
winter. Since no other woody plants exhibited such early leaf expansion phenology, honeysuckle is in an advantageous position to take up this nitrogen pulse. The results of Chapters 2 and 3 together provide strong support for a positive feedback between honeysuckle and soil processes and the existence of invasional meltdown between earthworms and honeysuckle. In Chapter 4, the temporal dynamics of inorganic, organic, and microbial biomass $\mathrm{C}$ and $\mathrm{N}$ pools were assessed with respect to honeysuckle presence and time since honeysuckle removal. The results from this analysis indicated that neither honeysuckle shrub presence nor time since removal were important factors in determining inorganic, organic, or microbial nutrient pools. Percent bare soil and soil moisture content were the most common factors predicting soil nutrient dynamics during each season. Overall, these results suggest that honeysuckle and exotic earthworms may form an 'invasional meltdown' leading to increasing rates of invasion and/or increased impacts on native communities and ecosystems. However, other factors may be more important in determining soil nutrient dynamics than L. maackii presence alone. 
TABLE OF CONTENTS

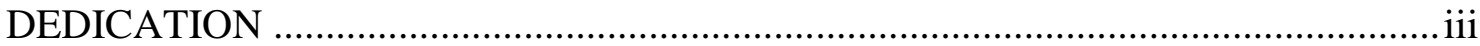

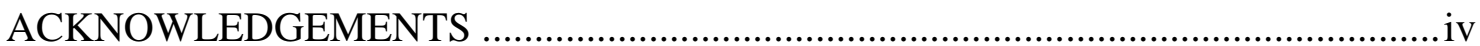

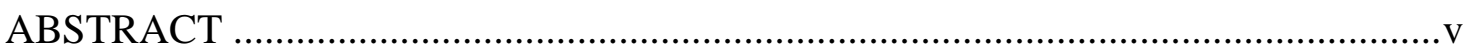

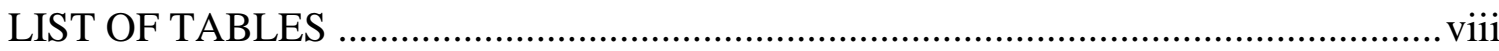

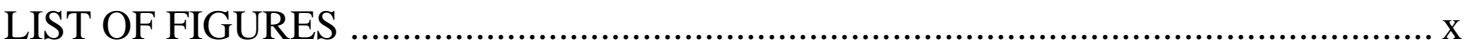

INTRODUCTION: A REVIEW OF THE ECOLOGY AND ECOSYSTEM

EFFECTS OF THE INVASIVE SHRUB, LONICERA MAACKII, AND

DISSERTATION RESEARCH OBJECTIVES ................................................... 1

EARTHWORM AND MACROINVERTEBRATE ACTIVITY RESPONSES

AFTER REMOVAL OF INVASIVE SHRUB HONEYSUCKLE FROM AN

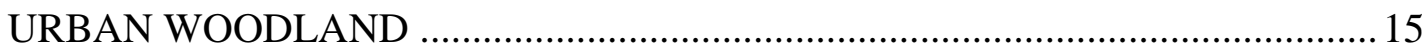

LEAF LITTER DECOMPOSITION AND NITROGEN RELEASE PATTERNS

IN AN URBAN WOODLAND INVADED BY EXOTIC HONEYSUCKLE

SHRUBS: THE EFFECTS OF LITTER MIXING AND SOIL

MACROINVERTEBRATES

60

SEASONAL SOIL NUTRIENT DYNAMICS OF A THREE-YEAR

HONEYSUCKLE SHRUB REMOVAL CHRONOSEQUENCE IN URBAN

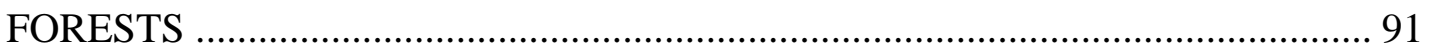

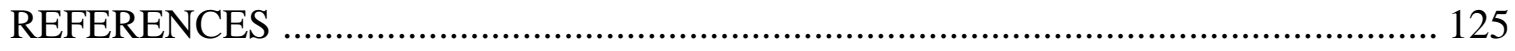

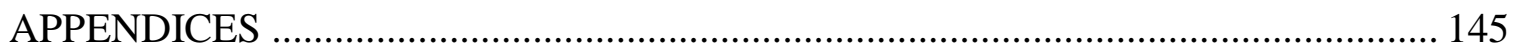

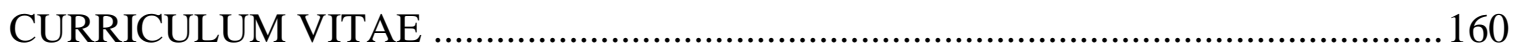




\section{LIST OF TABLES}

TABLE

PAGE

2.1. Earthworm study site locations.

2.2. Mean monthly air temperatures and total monthly precipitation levels for the winter months preceding the March 2012 and the March 2013 sampling periods.

2.3. Mean air temperature at ground level, mean soil temperature at $10 \mathrm{~cm}$, and mean soil moisture in the top $10 \mathrm{~cm}$ of soil at each earthworm collection date

2.4. Earthworm taxa and the juvenile demographic group used in all analyses.

2.5. Repeated measures analysis of variance results for earthworm biomass and density data.

2.6. Effects of L. maackii on adult worm species.

2.7. Effects of L. maackii on total, adult, and juvenile worm biomass and density.

2.8. The strongest overall multiple regression model for total earthworm biomass at each date.

2.9. Differences in decomposition of honeysuckle and sugar maple leaf litter in bags of two mesh sizes.

3.1. Study site locations for litterbag nutrient study.

3.2. Initial and subsequent $\mathrm{N}$ concentration and $\mathrm{C}: \mathrm{N}$ ratios of leaf litter and their mass remaining after 46 days in late winter to early spring.

3.3. Predicted versus actual values for the mixed leaf litter type in large and small mesh bags decaying over a 46 day period from late winter to early spring.

4.1. Study site locations for soil nutrient study.

4.2. Season groupings used for the best subset linear regression models. 
4.3. Repeated measures analysis of variance results for nutrient and microbial biomass data.

4.4. Relationships between nutrient pools and environmental variables 


\section{LIST OF FIGURES}

$\begin{array}{lll}\text { FIGURE PAGE } & \text { PAR }\end{array}$

2.1. Potential interactions between exotic earthworm species and the invasive shrub Lonicera maackii.

2.2. Mean total worm biomass (a), mean adult worm biomass (b), mean juvenile worm biomass (c), mean total worm density (d), mean adult worm density (e), and mean juvenile worm density (f).

2.3. Effect of mesh size on litter mass loss at different seasons of the year.

2.4. Index of soil macroinvertebrate activity at different seasons of the year using difference in mean percent mass lost between mesh sizes.

3.1. Mean percent mass remaining in honeysuckle shrub present (a) versus honeysuckle shrub removed (b) plots.

3.2. Changes in $\mathrm{N}$ mass remaining (\%), $\mathrm{N}$ concentration $\left(\mathrm{mg} \mathrm{N} \mathrm{g}^{-1}\right)$, and $\mathrm{C}: \mathrm{N}$ for honeysuckle shrub present $(a, b, c)$, and removed $(d, e, f)$ plots.

4.1. Changes over time in microbial biomass nitrogen for honeysuckle present (black) and honeysuckle removed (dotted) plots.

4.2. Changes over time in a) microbial biomass nitrogen (MC-N) and b) microbial biomass carbon (MB-C) in each of the chronosequence removals. 


\section{CHAPTER 1}

\section{INTRODUCTION: A REVIEW OF THE ECOLOGY AND ECOSYSTEM EFFECTS OF THE INVASIVE SHRUB, LONICERA MAACKII, AND DISSERTATION RESEARCH OBJECTIVES}

Of the estimated 138 exotic tree and shrub species that have become established in the United States (Pimentel et al. 2005), Amur honeysuckle (Lonicera maackii (Rupr) Herder) has become one of the most problematic and widely studied invasive shrubs. $L$. maackii is native to central and northeastern China, the Russian Far East, Korea, and Japan (Luken and Thieret 1996). The shrub was first introduced to North America in 1896 as an ornamental shrub and was subsequently promoted by the USDA Soil Conservation Service for erosion control and habitat restoration (Luken and Thieret 1996). Lonicera maackii has established populations in Ontario, Canada and 28 states in the United States (USDA NRCS 2014), with forests in the eastern and midwestern United States being particularly impacted by this invasive shrub. In this review, I will summarize the current literature regarding L. maackii and its effects on native forest communities and ecosystems. I will also outline the research objectives for my dissertation and demonstrate their importance to understanding the full range of impacts this shrub has on native forests. 


\section{Biology and ecophysiology}

\section{Species description and habitat}

L. maackii is described as an upright, multi-stemmed, deciduous shrub with hollow pith stems and up to $9 \mathrm{~cm}$ long ovate-elliptical leaves that are pubescent along the veins (Olsen and Cholewa 2009). The base of the shrub is comprised of a woody burl that gives rise to several stems and an extensive, but shallow, root system (Deering and Vankat 1999). Shrubs may grow to a height of $5 \mathrm{~m}$ (Olsen and Cholewa 2009) and have an annual growth rate as high as 0.4 m per year (Deering and Vankat 1999). L. maackii reaches sexual maturity in 3-8 years, at which time shrubs produce large numbers of fragrant, white flowers between May and early June that fade to yellow as they age (Olsen and Cholewa 2009; Goodell et al. 2010). During the late summer and autumn, mature shrubs produce an abundant crop of bright red fruits containing 1-10 seeds each (Luken and Thieret 1996; Deering and Vankat 1999; Goodell et al. 2010). These fruits ripen between September and November and remain on shrubs until extreme cold or heavy precipitation occurs (Ingold and Craycraft 1983; Luken and Thieret 1996; Goodell et al. 2010). Seeds are primarily dispersed by birds, including American robins (Turdus migratorius), cedar waxwings (Bombycilla cedrorum), European starlings (Sturnus vulgaris), hermit thrushes (Catharus guttatus), and northern mockingbird (Mimus polyglottos) (Ingold and Craycraft 1983; Bartuszevige and Gorchov 2006). White-tailed deer (Odocoileus virginianus) may also act as long distance dispersers (Castellano and Gorchov 2013). In its native range, L. maackii is commonly found in habitats characterized by high light availability and disturbance, such as open woodlands, floodplain forests, and scrub communities (Luken et al. 1995). In its invaded range, it is 
abundant in a variety of open habitat types including old fields, forest edges, and forest interiors that have undergone significant canopy disturbance (Luken and Goessling 1995; Luken and Thieret 1996). Urban forests and woodlands may be particularly vulnerable to invasion by L. maackii as they are often characterized by high levels of fragmentation and disturbance (Hutchinson and Vankat 1997; Borgmann and Rodewald 2005; Trammell and Carreiro 2011; White et al. in press). Invaded urban systems may then serve as focal points for L. maackii invasion into surrounding woodlands (Bartuszevige et al. 2006).

\section{Leaf phenology}

L. maackii has been described as shade intolerant due to its reduced production, decreased resilience against clipping, and reduced reproductive capacity in forests versus open habitats (Luken 1988; Luken 1990; Luken and Mattimiro 1991; Luken et al. 1995). However, an extended leaf phenology gives this shrub a longer photosynthetic season compared to native competitors and allows it to persist and spread in shady, forest interiors (Luken et al. 1995; McEwan et al. 2009a). L. maackii breaks bud during the late winter to very early spring and retains its leaves later in the fall than most natives in the canopy and understory (Trisel and Gorchov 1994), a trait that may be attributed to its superior cold tolerance (McEwan et al. 2009a). This may allow L. maackii to take advantage of the high light conditions in the forest understory during the spring and fall months when the tree canopy is leafless, resulting in a longer growing season and enhancing the shrub's net carbon gain. For example, Harrington et al. (1989) found that early spring foliage was responsible for up to a third of Lonicera $x$ bella's annual carbon 
gain. A plastic morphology and physiology in response to higher light condition may also allow L. maackii to take advantage of canopy thinning and forest fragmentation before shade-tolerant, low resource-adapted natives (Luken et al. 1997b).

\section{Germination and seedling establishment}

Unlike many native species, L. maackii does not form a persistent seed bank (Luken and Mattimiro 1991; Luken and Goessling 1995) and L. maackii seeds do not display well developed dormancy mechanisms (Luken and Goessling 1995; Hidayati et al. 2000). According to a study by Hidayati et al. (2000), only 50\% of L. maackii seed tested required warm or cold stratification to emerge from dormancy, while the remaining $50 \%$ did not require any form of stratification to germinate. Laboratory germination rates have been reported to range from $27-55 \%$ in complete darkness to $48-81 \%$ in light (Luken and Goessling 1995; Hidayati et al. 2000). As a result, germination of L. maackii seeds may occur at any time of the year, though peak germination times occur during warm wet periods in late winter and early spring (Luken and Thieret 1996).

Other factors may also influence the germination rates and seedling establishment in Lonicera maackii. Germination may be inhibited by anaerobic conditions that develop during prolonged flooding in bottomland areas (Swab et al. 2008) or prolonged ( $\geq 12$ months) periods of dryness (Hidayati et al. 2002). Orrock et al. (2012) reported that fungal seed pathogens cause significant seed mortality in L. maackii, but that pathogen attack of honeysuckle seeds was density dependent. This suggests that changes in the soil chemical environment and/or microclimate following L. maackii invasion may be important in mediating fungal effects on seed mortality. Fruit consumption may facilitate 
or inhibit seed germination in L. maackii depending on the species. Gut passage through American robins does not inhibit germination and these birds preferentially dispersed seeds into suitable habitat types (Bartuszevige and Gorchov 2006). Conversely, gut passage through cedar waxwings was found to inhibit germination of L. maackii seedling by Bartuszevige and Gorchov (2006). Seedling establishment was reported to be significantly higher in forests compared to open habitats by Luken and Mattimiro (1991); however, heavy shading can reduce seedling growth (Luken et al. 1995). While gap formation and soil disturbance do not seem to promote increased seedling establishment (Luken et al. 1997a), bare soil and low litter areas have been shown to have significantly higher establishment compared to locations with deep litter layers (Bartuszevige et al. 2007; Wilson et al. 2013). Furthermore, a study by Wilson et al. (2013) in second-growth forests in central Kentucky found a negative relationship between honeysuckle presence and oak (Quercus spp.) litter, suggesting that oak-dominated forests may be more resistant to invasion from these shrubs.

\section{Effects on animal and plant communities}

\section{Invertebrates}

L. maackii effects on invertebrates have been mixed. The flowers of L. maackii offer nectar and pollen rewards to pollinator species and both non-native and native bees are known to utilize L. maackii shrubs as a food source (Goodell et al 2010). Buddle et al. (2004) proposed that reduced ground-layer habitat complexity beneath L. maackii shrubs was responsible for the low diversity of ground-dwelling spider species observed along hedgerows in the Midwest. Allelochemicals present in the leaves, fruits, and roots of $L$. 
maackii (Cipollini et al. 2008b; McEwan et al. 2009b) and changes in microclimate may have direct and indirect effects on invertebrate species. Christopher and Cameron (2012) reported that Amur honeysuckle did not change total arthropod diversity but did increase abundance and change the taxonomic composition of litter-dwelling arthropod communities in the absence of white tailed deer in a southwestern Ohio forest. In particular, Acari were more abundant in honeysuckle present plots while Araneae were significantly more abundant in honeysuckle absent plots. Christopher and Cameron (2012) speculated that allelopathic chemicals present in L. maackii may have reduced bacteria and fungi at the soil surface, potentially decreasing food availability and therefore prey abundance for Araneae. Higher Acari abundance was attributed to decrease in Araneae abundance or potentially to favorable changes in the microclimate beneath honeysuckle shrubs. Invasive gypsy moths (Lymantria dispar) consumed little to no honeysuckle in a feeding trial experiment conducted by McEwan et al. (2009b), and all moths feeding on honeysuckle died prior to molting. Extracts of L. maackii leaves have been shown to deter feeding by the generalist herbivore beet armyworm (Spodoptera exigua) in a choice bioassay (Cipollini et al. 2008b). A choice feeding bioassay conducted by Lieurance and Cipollini (2013) reported that L. maackii was able to serve as a suitable host for the generalist herbivore fall armyworm (Spodoptera exigua) and the honeysuckle specialist sawfly (Zaraea inflate). However, L. maackii leaves experienced substantially lower amounts of herbivory from fall armyworms and honeysuckle specialist sawflies than the native Lonicera reticulata (grape honeysuckle). This suggests that L. maackii shrubs may be able to escape herbivory due to the inability of herbivores to recognize Amur honeysuckle as a potential host. 


\section{Birds}

Dense thickets of $L$. maackii may benefit some bird species by increasing foraging and nesting sites but harm others by increasing the risk of predation and parasitism. Despite being a poor quality food resource (Ingold and Craycraft 1983), many species of birds are known to consume the fruit of L. maackii (Ingold and Craycraft 1983; Bartuszevige and Gorchov 2006). Abundant fruit production by honeysuckle shrubs has been associated with greater densities of frugivorous birds in winter (McCusker et al. 2010). McCusker et al. (2010) observed higher densities of understory bird species and lower densities of select canopy species in sites invaded by honeysuckle shrubs. This suggests that understory species may benefit from increased food and nesting resources, but dense shrub thickets may negatively affect canopy species such as eastern woodpewees (Contopus virens) by prohibiting efficient, aerially foraging. However, songbirds nesting in L. maackii thickets may be at higher risk for predation (Schmidt and Whelan 1999) due to lower nest height, absence of thorns on honeysuckle shrubs, and branch architecture that facilities predator movement. Borgmann and Rodewald (2004) reported that the nests of American robins and northern cardinals (Cardinalis cardinalis) were twice as likely to be depredated in urbanized landscapes with exotic shrubs compared to landscapes featuring native substrates. Furthermore, parasitism of Acadian flycatcher (Empidonax virescens) by brown-headed cowbirds (Molothrus ater) was found to be higher in areas with Lonicera maacki by Rodewald (2009). This suggests that in addition to increasing predation risks, honeysuckle shrubs may also increase the risk of nest parasitism by increasing the search efficiency of cowbirds or by concentrating host nests in the forest shrub layer. 
The negative effects of honeysuckle on bird species may be restricted to the early portion of the breeding season. Rodewald et al. (2010) reported very low nest survival rates in honeysuckle during the early part of the breeding season (i.e. $14 \%$ chance of nest survival over 21 days); however, nest survival rates in honeysuckle patches rose throughout the season and eventually surpassed the nest survival rate in native substrates towards the end of the breeding season. Northern cardinals are known to preferentially nest in honeysuckle shrubs (Leston and Rodewald 2006) and pairs that first nested in $L$. maackii were reported to fledge $20 \%$ fewer offspring than cardinals nesting in other substrates by Rodewald et al. (2010). This suggests that L. maackii may act as an “ephemeral ecological trap" for certain species or for birds which arrive early in the breeding season (Rodewald et al. 2010).

\section{Amphibians and Mammals}

L. maackii may affect amphibians through the production of allelopathic chemicals and alterations in the microclimate. Field experiments by Watling et al. (2011c) found that pools inoculated with L. maackii extracts accelerated the development of American toad tadpoles (Anaxyrus americanus) but did not increase tadpole mortality. Conversely, laboratory experiments conducted by Watling et al. (2011a) showed that extracts from L. maackii increased mortality in American toad tadpoles and increased surfacing trips by American toad and plains leopard frog (Lithobates blairi) tadpoles. Watling et al. (2011b) reported lower amphibian species richness and evenness in forested areas invaded by L. maackii. Furthermore, areas invaded by honeysuckle shrubs had twice as many Green frogs (Lithobates clamitans) and fewer Pickerel frogs 
(Lithobates palustris) compared to uninvaded sites. Watling et al. (2011b) attributed shifts in amphibian species composition to cooler temperature under L. maackii invaded sites.

Cover provided by L. maackii thickets may affect the behavior of mammals. Meiners (2007) found that the risk of seed predation from white-footed mice (Peromyscus leucopus) for native tree seeds was $59 \%$ higher in areas invaded by honeysuckle compared to areas where it had been removed. Higher rates of seed predation beneath honeysuckle thickets may be due to lower perceived predation risk by seed foragers like white-footed mice. However, lower perceived predation risk beneath shrubs may also depend on other environmental (e.g. weather) and foraging cost (e.g. temperature) correlates (Mattos and Orrock 2010). Similarly, Dutra et al. (2011) reported that the dense cover provided by L. maackii shrubs lead to higher foraging activity among mice, particularly on cloudless nights. L. maackii shrubs were also found to increase the foraging activity of raccoons (Procyon lotor) and Virginia opossums (Didelphis virginiana), though shrubs did not seem to influence squirrel activity (Dutra et al. 2011).

\section{Plants}

The effects of Lonicera maackii on native plant communities have been particularly well studied. Invasion by L. maackii following canopy disturbance has shifted forest understory composition from having a relatively sparse shrub layer but dense herbaceous layer to one comprised of a dense, monoculture shrub layer with an essentially non-existent herbaceous layer (Collier et al 2002; Hartman and McCarthy 2008). Numerous studies have found strong, negative correlations between L. maackii 
cover and native herbaceous and woody species populations. Hutchinson and Vankat (1997) found strong, negative correlations between L. maackii cover and native tree seedling density, tree seedling species richness, and herb cover. Collier et al. (2002) reported that $86 \%$ of herb species and $100 \%$ tree species in southwestern Ohio forests had significantly lower cover beneath L. maackii shrubs. Similarly, Hartman and McCarthy (2008) found that sites with long histories of L. maackii presence displayed lower densities and species richness in the herbaceous, seedling, and sapling layers. While Amur honeysuckle may offer some protection from deer browsing for tree seedlings, the presence of these shrubs leads to an overall increase in tree seedling mortality (Gorchov and Trisel 2003). By expanding its leaves earlier in the spring than native species, $L$. maackii increases shading during the critical period of early spring when light availability would normally be high due to the canopy being leafless. Increased shading is the most commonly cited mechanism to explain the negative impacts of $L$. maackii on native herbs and tree species (Gould and Gorchow 2000; Miller and Gorchov 2004) and may also result in decreased pollinator visitation in native plant species (McKinney and Goodell 2010).

Increased seed predation and allelopathy may provide an alternate mechanism by which L. maackii shrubs decrease the growth and fecundity of native plants. Tree seeds under L. maackii shrubs experience greater risk for seed predation from white-footed mice compared to tree seeds in more open areas (Meiners 2007). This may allow honeysuckle seeds to escape predation while also reducing competition from native shade-tolerant tree species. Extracts produced from the leaves and root of Lonicera maackii have been shown to decrease the germination of orange jewelweed (Impatiens 
capensis), garlic mustard (Alliaria petiolata), and thale cress (Arabidopsis thaliana) in the laboratory (Dorning and Cipollini 2006). Similarly, Cipollini et al. (2008a) reported thale cress to display reduced growth, decreased reproduction, and a constrained ability to responsed to higher nutrient availability after honeysuckle extracts were applied to soils. McEwan et al. (2010) reported that chemicals contained in L. maackii foliage and berries reduced the germination of tall fescue (Festuca arundinacea), dwarf white impatiens (Impatiens walleriana), lancelead tickseed (Coreopsis lanceolata), and Kentucky bluegrass (Poa pratensis). However, these responses were species-specific, tissuespecific, and sometimes the same as responses to co-occurring native shrubs, indicating that allelopathic interactions are complex and generalizations may be difficult.

\section{Effects on ecosystem processes}

Alterations in the quality, quantity, and timing of leaf litter and nutrient inputs by Lonicera maackii may have important impacts on decomposition and nitrogen cycling dynamics. While leaf senescence in most native species occurs from mid-September to early October, L. maackii typically retains its leaves longer than co-occurring woody natives and leaf abscission typically does not occur until late November through midDecember (McEwan et al 2009a). The dense shrub thickets formed by L. maackii may act as a barrier to canopy leaf litter, redirecting litter from the canopy to areas where shrubs are not present (McNeish et al 2014). Furthermore, leaf litter of Amur honeysuckle has a lower C:N ratio, lower percent lignin, lower lignin: $\mathrm{N}$ ratio, and lower lignocellulose index (LCI) compared to co-occuring natives such as sugar maple (Acer saccharum), white ash (Fraxinus americana), blue ash (Fraxinus quadrangulata), chikapin oak 
(Quercus muehlenbergii), and shagbark hickory (Carya ovata) (Arthur et al. 2012;

Poulette and Arthur 2012; Trammell et al. 2012). Decomposition rates for honeysuckle litter have been reported to be three to four times faster than sugar maple (Blair and Stowasser 2009; Trammell et al. 2012), five times faster than white ash and hickory (Arthur et al. 2012), and 21 times faster than northern red oak (Quercus rubra) (Blair and Stowasser 2009). L. maackii has also been reported to release nitrogen more rapidly than sugar maple, ash, oak, or hickory litters (Poulette and Arthur 2012; Trammell et al. 2012). Poulette and Arthur (2012) reported that no synergistic or antagonistic mass loss effects were observed when honeysuckle was mixed with native ash, oak, and hickory litters. These mixtures did result in synergistic $\mathrm{N}$ losses; however, the timing of these losses varied between species mixtures. The results from the Poulette and Arthur (2012) study suggest that honeysuckle litter may alter the decomposition dynamics of native tree litters, but that the timing of these effects may vary by species. A study by McEwan et al. (2012) showed that interception of rainfall by L. maackii shrubs led to significant decreases in the volume of rain reaching the forest floor. In addition, throughfall collected from beneath honeysuckle shrubs had higher cation and lower ammonium concentrations than rainwater captured away from shrubs, suggesting that honeysuckle shrubs may alter moisture and nutrient inputs to soils.

L. maackii may also impact the productivity of invaded ecosystems. Luken (1988) reported aboveground net primary productivity (ANPP) estimates in L. maackii growing in northern Kentucky to range from 159-553 $\mathrm{g} \mathrm{m}^{-2}$ year $^{-1}$ for forest-grown shrubs to 141$1350 \mathrm{~g} \mathrm{~m}^{-2}$ year $^{-1}$ for shrubs grown in open habitats. These estimates fall within the range of mean annual ANPP (513-1,156 $\mathrm{g} \mathrm{m}^{-2}$ year $\left.^{-1}\right)$ reported for temperate forests in eastern 
Kentucky (Newman et al. 2006). In terms of foliar biomass, Trammell et al. (2012) found that highway verge forests with high densities of L. maackii had 1.5 times less total foliar biomass compared to low density honeysuckle sites with equivalent tree basal area. This suggests that overall productivity in forests may decline as honeysuckle shrubs invade. Dendrochronological techniques used by Hartman and McCarthy (2007) indicated that $41 \%$ of trees in southwestern Ohio forests experienced negative growth changes following L. maackii invasion, with large reductions occurring 20 years after the initial invasion. These results suggest that invasion by Amur honeysuckle may have both shortterm (e.g. decomposition, altered nutrient cycling) and long-term (e.g. reduced tree growth, decreased productivity, decreased tree regenerations) impacts on native forests.

\section{Dissertation objectives}

Despite the vast amount of research on L. maackii's impacts on native plant communities, the effects of these shrubs on soil communities and nutrient cycling are still relatively unknown. Arthur et al. (2012) reported that the microbial community on Amur honeysuckle litter was distinct from microbial communities on white ash and hickory. However, no studies in the literature have examined how these shrubs influence soil microbial biomass dynamics or soil macroinvertebrates. In this dissertation, I address this knowledge gap by examining how shrub honeysuckle affects exotic earthworm populations, soil microbial biomass, and nutrient cycling in urban woodlands. This dissertation contains three research chapters:

Chapter 2. Earthworm and macroinvertebrate activity responses after removal of invasive shrub honeysuckle from an urban woodland park. 
Chapter 3. Leaf litter decomposition and nitrogen release patterns in an urban woodland invaded by exotic honeysuckle shrubs: The effects of litter mixing and soil macroinvertebrates.

Chapter 4. Seasonal soil nutrient dynamics of a three-year honeysuckle shrub removal chronosequence in urban forests.

In Chapter 2, I determine if L. maackii shrubs promote higher populations of exotic earthworms, how active soil macroinvertebrates (including earthworms) are in decaying invasive and native litters throughout the year, and whether a potential feedback loop exists between exotic earthworms and invasive honeysuckle shrubs. In Chapter 3, the effects of mixing honeysuckle and sugar maple litter are examined in the presence and absence of soil macroinvertebrate detritivores. This study focuses on the late winter to early spring because that is a time when a) honeysuckle litter is still a significant component of the leaf litter layers, and b) honeysuckle shrubs are active while native woody species are not. In Chapter 4, the temporal dynamics of inorganic (ammonium, nitrate, dissolved total inorganic nitrogen) and organic (dissolved organic carbon, dissolved organic nitrogen, microbial biomass $\mathrm{C}$ and $\mathrm{N}$ ) nutrient pools are examined in the presence and absence of shrub honeysuckle. A three-year chronosequence of shrub removal was used to determine the effects of shrub removal on soil nutrient pools and whether those effects changed with time since removal. The results presented in this dissertation represent a comprehensive attempt to understand how Lonicera maackii impacts soil microbial biomass and soil nutrient dynamics and whether a potential feedback loop exists between exotic earthworms and invasive honeysuckle shrubs. 


\section{CHAPTER II}

\section{EARTHWORM AND MACROINVERTEBRATE ACTIVITY RESPONSES AFTER REMOVAL OF INVASIVE SHRUB HONEYSUCKLE FROM AN URBAN WOODLAND PARK}

\section{$\underline{\text { Introduction }}$}

Increased habitat disturbance and expansion of global trade networks are promoting an upward trend in both the frequency and severity of biological invasions (Vitousek et al. 1997; Hulme 2009). Thus, it is increasingly likely that ecosystems will support not one, but multiple, co-occurring invasive species. As such, understanding interactions between co-existing invasive species and the combined impacts they have on native ecosystems must become a priority for both managers and researchers. This is particularly true in urban ecosystems, which tend to be characterized by greater levels of disturbance, less diverse species assemblages, and higher numbers of non-native species (McKinney 2002; Alberti et al. 2003; Zipperer and Guntenspergen 2009). In these environments, interactions between multiple co-occurring invasive species can range from mutually detrimental to mutually facilitative (Simberloff and Von Holle 1999). Depending on their interaction, the impacts of co-occurring invasive species may be additive (i.e., the sum of individual effects of each invader), mitigated (i.e., the combined effects of each invader cancel one another out), or magnified (i.e., the combined effects 
of each invader are greater than the sum of each invader alone) (Kuebbing et al. 2013). It is this last scenario that Simberloff and Von Holle (1999) described with the concept of ‘invasional meltdown', a scenario in which mutual facilitation between two or more invasive species magnifies the impacts of invasion and/or leads to increased rates of invasion.

Though research in the field of invasion ecology has grown rapidly since the 1980s, most studies have focused on aboveground, single-species invasions and their effects on native species and ecosystems (Simberloff 2011; Kuebbing et al. 2013). However, interactions and feedbacks between the above- and belowground components of ecosystems can also be important in controlling ecosystem processes (Wardle et al. 2004). In this study, I examine the interaction between the invasive shrub Lonicera maackii (Amur honeysuckle) and invasive Eurasian earthworms and describe how these interactions may fit the model of 'invasional meltdown'. First introduced to North America in 1896 as an ornamental shrub (Luken and Thieret 1996), L. maackii has become one of the most abundant and problematic exotic shrubs in mid-western and eastern forests, with established populations existing in Ontario, Canada and 28 states in the United States (USDA NRCS 2014). Like many other invasive plant species, $L$. maackii displays a number of traits that have contributed to its success as an invader, including an extended leaf phenology (Trisel and Gorchov 1994), an ability to sprout after cutting (Luken 1990), a plastic branch architecture (Luken et al. 1995), and a high allocation of energy towards reproduction (Ingold and Craycraft 1983). Establishment of L. maackii is facilitated by canopy disturbance and gap formation (Luken and Goessling 1995), and as invasion proceeds, relatively open forest understories are replaced by dense 
monocultures of L. maackii shrubs (Collier et al. 2002). As a consequence, shading by these shrubs can negatively affect the abundance, richness, growth, and regeneration of herbaceous and woody natives (Hutchinson and Vankat 1997; Gould and Gorchov 2000; Collier et al. 2002; Gorchev and Trisel 2003; Hartman and McCarthy 2004; Miller and Gorchov 2004).

The introduction of exotic earthworm species to North America is believed to have begun with the arrival of the first European settlers (Gates 1966; Reynolds 1994). As detritivores that ingest and incorporate organic matter into mineral soil, invasive earthworms have the ability to alter both the physical and chemical characteristics of soils as well as the composition, structure, and function of native ecosystems (James and Hendrix 2004; Hale et al. 2005b; Frelich et al. 2006). The passage of soil through the gut of earthworms has been reported to decrease soil microbial biomass (Wolters and Joergenson 1992; Bohlen and Edwards 1995; Devliegher and Verstraete 1995; Saetre 1998). Conversely, other studies have reported that the incorporation of organic material into mineral soil by exotic earthworms increases soil microbial biomass (Burtelow et al. 1998; Bohlen et al 1999; Li et al. 2002; Groffman et al. 2004). Modification of the soil matrix coupled with the feeding activity of earthworms can increase litter decomposition rates (Suárez et al. 2006; Holdsworth et al. 2008), change the availability and retention of soil carbon, nitrogen, and phosphorus (Bohlen et al. 2004a,b; Suárez et al. 2004; Hale et al. 2005b; Szlavecz et al. 2006), alter the size and structure of soil microbial (McLean and Parkinson 2000; Groffman et al. 2004; McLean et al. 2006; Dempsey et al. 2011) and soil microfauna communities (McLean and Parkinson 1998; Migge-Kleian et al. 2006), affect the abundance of arbuscular mycorrhizal fungi populations (Lawrence et al. 2003), 
and change the distribution of plant fine roots (Fisk et al. 2004). Depletion of the organic horizons and leaf litter layers by exotic earthworms can negatively impact the diversity and abundance of native plant species (Gundale 2002; Hale et al. 2006; Nuzzo et al. 2009; Hopfensperger et al. 2011), though the magnitude of these effects may vary depending on site factors and the species of earthworm involved (Bohlen et al. 2004c, Hale et al. 2005b; Hale et al. 2006; Holdsworth et al. 2007).

Earthworms are commonly classified into recognized functional groups: epigeic, endogeic, and anecic (Bouché 1977). Epigeic worms tend to be small, pigmented species that have high reproductive rates and live and feed at the soil surface. Endogeic worms are non- or lightly pigmented worms that construct complex, horizontal burrows in the mineral horizon and feed on organic materials within the soil. Anecic worms are large and feed on surface litter, but live in deep, vertical burrows that extend into the mineral soil horizon. While these classifications are useful for describing the behavior of most earthworm species, not all species can be easily classified into a single group. For example, Lumbricus rubellus has been described as an "epi-endogeic" species because it removes and incorporates litter into the upper soil horizons to a much greater extent than other epigeic species (Hale et al. 2005a; Addison 2009). These functional groups are also useful in determining the stage of invasion. Earthworm invasions typically occur in waves, with small, easily transported epigeic species arriving first and peaking during the earlier stages of invasion (Hale et al. 2005a; Suárez et al. 2006; Addison 2009). As invasion proceeds, the activity of epigeic species may facilitate the establishment of stable populations of endogeic (e.g. Aporrectodea spp) and anecic (e.g. L. terrestris) earthworms. During the late stages of invasion, endogeic and anecic worms consume the 
annual litter inputs needed by epigeic worms, causing the decline and disappearance of epigeic species (Hale et al. 2005a; Eisenhauer et al. 2007; Holdsworth et al. 2007).

To determine whether there is the potential for an invasional meltdown between exotic earthworms and L. maackii, I conducted a study to examine earthworm populations and macroinvertebrate activity levels in areas where shrub honeysuckle was present versus where it had been removed. The goals for this study were to: (1) determine the effects of $L$. maackii on earthworm biomass and density and whether these effects change seasonally; (2) examine whether increases in honeysuckle density lead to corresponding increases in total earthworm biomass; and (3) assess the activity of soil macroinvertebrates (including earthworms) in decaying litter during different seasons of the year and explore whether this activity is influenced by L. maackii. Honeysuckle shrubs may promote the abundance of invasive earthworms and other macroinvertebrates by providing high quality leaf litter (i.e. food source) during the winter through early spring. In the summer, honeysuckle shrubs may further promote invasive earthworms by creating a more favorable soil microclimate via shading. I predicted that earthworm biomass and density would be higher where L. maackii is present than where it had been removed previously, and that both would increase with increasing honeysuckle density. Additionally, I predicted that soil macroinvertebrates (including exotic earthworms) would prefer high quality honeysuckle litter over the lower quality sugar maple litter. Finally, I hypothesized that the presence of the shrubs would affect macroinvertebrate activity, but that the strength of that effect would vary seasonally. Rapid turnover of leaf litter by earthworms and other macroinvertebrates during the late winter to early spring might create labile pools of nitrogen at a time of year when honeysuckle is breaking bud 
but most native tree and shrub species are still dormant. Because of their extended leaf phenology, invasive honeysuckle shrubs may be optimally positioned to exploit an early season nutrient pulse created by the activity of earthworms and other macroinvertebrates. During other seasons, macroinvertebrate detritivores may further enhance the success of L. maackii by reducing the leaf litter layer and creating bare soil conditions that favor honeysuckle seed germination and establishment (Bartuszevige et al. 2007; Wilson et al. 2013). This may create a positive feedback loop between invasive honeysuckle shrubs and exotic earthworms and create the potential for an invasional meltdown (Fig. 2.1).

\section{$\underline{\text { Methods }}$}

\section{Study area}

Eight study sites were established between January and March of 2008 in Cherokee Park, a 166-ha forested park in Louisville, KY, USA $\left(38^{\circ} 14^{\prime} 28.32^{\prime \prime} \mathrm{N}\right.$, $\left.85^{\circ} 41^{\prime} 48.84^{\prime \prime} \mathrm{W}\right)$. White ash (Fraxinus americana L.), sugar maple (Acer saccharum Marsh.), common hackberry (Celtis occidentalis L.), and tulip poplar (Liriodendron tulipifera L.) were the most common dominant or co-dominant species in the tree canopy, and basal area of trees $\geq 2.5 \mathrm{~cm} \mathrm{DBH}$ ranged from 3.4 to $52.5 \mathrm{~m}^{2} \mathrm{ha}^{-1}$ (M. Carreiro, unpublished). Soils varied between well-drained, moderately deep Hapludalfs in the Caneyville series and very deep Paleudalfs in the Crider series. Slopes ranged from moderately steep (10-30 percent slope) to steep (30-60 percent slope). The mean annual temperature is $13.8^{\circ} \mathrm{C}$ and the region is characterized by warm, humid summers (mean July temperatures of $25.8^{\circ} \mathrm{C}$ ) and cool winters (mean January temperatures of $0.5^{\circ} \mathrm{C}$ ) (NCDC 2012). Precipitation is evenly distributed throughout the year, with a mean 
annual precipitation of $113 \mathrm{~cm}$ (Klebler 2000). Sites were chosen to produce a range of honeysuckle stem densities and basal areas (Table 2.1).

In 2008, two 10x10 m plots were delineated at each site with a minimum five $\mathrm{m}$ buffer zone separating and surrounding each plot. In January of 2009, one plot at each site was randomly selected and all honeysuckle shrubs were killed and removed within the selected plots. Shrubs in the surrounding buffer zone were not removed. This study was conducted in 2012-2013 (i.e. the fourth and fifth growing seasons after shrub removal), giving these plots some time to equilibrate to the shrub removals. Though invasive honeysuckle shrubs were the dominant shrub species at most sites, other shrub species were also present in some plots. The exotic shrubs Ligustrum sinense (Chinese privet) and Rhamnus cathartica (common buckthorn) were present at multiple plots and L. sinense had very high stem densities $\left(305\right.$ stems per $\left.100 \mathrm{~m}^{2}\right)$ in one of the honeysuckle removal plots. The native shrubs, Staphylea trifolia (American bladdernut) and Lindera benzoin (northern spicebush) were also present in a few plots at low stem densities (12-28

stems per $100 \mathrm{~m}^{2}$ ). These shrubs, when present, were left in the removal plots (Table 2.1). Freshly cut honeysuckle stumps were painted with $26 \%$ glyphosate isopropylamine salt solution (Roundup; Monsanto Company, St. Louis, MO, USA) and treated again if necessary to ensure shrub death. No additional shrub removals or herbicide treatments were applied after 2009 to avoid confounding herbicide and shrub removal effects.

\section{Shrub sampling}

Honeysuckle shrub density and basal area data was collected in August of 2012. As smaller shrubs did not provide significant contributions to shading or litter inputs at 
our sites, the shrub survey was restricted to include only shrubs that were $\geq 1 \mathrm{~m}$ in height. Stem density was measured by totaling the number of live basal stems from each shrub within a plot. The diameter at root collar was measured approximately 1 inch above soil level to calculate the basal area of shrubs $\left(\mathrm{BA}=\pi \mathrm{r}^{2}\right)$. Stem density and shrub basal area were converted to a ha ${ }^{-1}$ basis to allow for comparisons with other studies. Density and basal area data from honeysuckle present plots were used to explore shrub density effects on earthworm populations. Honeysuckle present plots contained a wide range of honeysuckle densities and basal areas and excluding removals allowed me to avoid including plots dominated by other exotic shrub species (Table 2.1).

\section{Earthworm sampling}

The initial study was designed to capture seasonal dynamics in earthworm abundance and biomass at specific times representing seasons of the year and included sample collections in March, June, September, and November of 2012. The winter months preceding the March 2012 study period were unusually warm for our region (Table 2.2). This presented an opportunity to compare the effects of contrasting winter conditions in 2012 (warmer than normal) with that of the more normal winter of 2013 on early spring earthworm populations. Therefore, a March 2013 sampling date was added to the study after the initial four samples had been collected.

Earthworm samples were collected using an aqueous mustard extraction technique modified from Clapperton et al. (2007). A solution consisting of $75 \mathrm{~g}$ of spicy mustard powder (Extra Hot Mustard Seed Powder; Frontier Co-op, Norway, IA, USA) dissolved in $7 \mathrm{~L}$ of tap water was applied slowly to soil within a $0.5 \times 0.5 \mathrm{~m}$ sampling 
frame. Before applying the mustard solution, all surface debris was removed from within the sampling frame. Any earthworms found within the surface debris (i.e. epigeic) or that emerged within 15 minutes of the solution being applied (i.e. endogeic and anecic) were collected and placed into plastic containers with wet paper towels and vented lids. Three samples were randomly collected within each plot at each sampling date and the earthworms pooled together to calculate oven dry mass (ODM). Because oven drying is a destructive process, an additional sample was taken within $0.5 \mathrm{~m}$ of each of the three ODM samples for species identification and species counts. All samples were taken at least 1.0 meter away from the plot edge and survey flags were used to mark sampled areas to prevent resampling the same areas over the year. Earthworms were transported to the lab in coolers and then placed in a cool, dark area for 48 hours to void gut contents. Before weighing, worms were lightly rinsed with deionized water and euthanized in a $50 \%$ isopropyl alcohol solution. ODM samples were sorted by species using Dindal (1990), oven dried at $60^{\circ} \mathrm{C}$ for 48 hours, and weighed. Samples taken for species identification / preservation were euthanized in a 50\% isopropyl alcohol solution, placed in a $10 \%$ formalin solution for 48 hours, and then transferred to a $90 \%$ isopropyl alcohol solution for identification and preservation.

Unlike Canada and the northern continental United States, Kentucky remained ice-free during the Pleistocene glaciations (Gates 1977; James 2004) and its soils are inhabited by both native and exotic earthworm species (Dotson and Kalisz 1989; Kalisz and Dotson 1989). In a review of earthworm invasion into temperate and tropical ecosystems, Hendrix et al. (2006) concluded that earthworm invasion into regions with native populations may (a) fail to establish stable and persistent exotic populations, (b) 
result in the extirpation of native worms and the formation of exotic-only assemblages, or (c) lead to co-occurring populations of native and exotic species. Therefore, earthworm assemblages at our sites could potentially support native and/or exotic species. Because of this, representative samples were sent to the Natural Resources Research Institute (University of Minnesota, MN, USA) for species verification.

\section{Litterbag experiment}

To determine the seasonal importance of $L$. maackii presence on the activity of soil macroinvertebrate detritivores, I performed a litter decomposition experiment with litterbags of two different size meshes and two leaf litter types (honeysuckle and sugar maple), to assay their activity. Senesced sugar maple (Acer saccharum) and honeysuckle (L. maackii) leaves were collected in October 2011 and December 2011, respectively, using plastic tarps placed on the ground before leaf fall. Two collection periods were necessary due to the different timing of leaf senescence between sugar maple (OctoberNovember) and honeysuckle (December-January). Sugar maple was selected as a native comparison litter to honeysuckle for two reasons. First, sugar maple is the most abundant canopy species throughout Cherokee Park (Olmsted Park Conservancy, unpublished report) and its litter is a major component of annual litter fall. Second, native shrubs were largely absent from the park, making it impossible to use a comparable native shrub litter (e.g. Lindera benzoin). Collections were made every three days for three weeks and any captured leaves were transported to a heated warehouse and allowed to air dry on large plastic tarps for a period of two months. Leaves were turned weekly for the first three 
weeks to allow for proper drying. Prior to being placed in litterbags, leaves were sorted by species and collections from different dates were pooled and mixed.

Litterbags of two different mesh sizes were used for this experiment. Small-mesh bags were constructed using fiberglass window screening (Gray Fiberglass Screen Wire, New York Wire, Grand Island, NY, USA) with a 1 x $1 \mathrm{~mm}$ mesh size while large-mesh bags were constructed using polypropylene pond netting (Pond and Pool netting, Dalen, Knoxville, TN, USA) with a $10 \times 10 \mathrm{~mm}$ mesh size. The mesh size of small-mesh bags was large enough to allow soil microbes and mesofauna to access litter but was small enough to restrict macroinvertebrates (e.g. earthworms, isopods, millipedes) from colonizing and feeding on litter. In contrast, the mesh size of large-mesh bags was large enough to allow soil macroinvertebrates access to leaf litter. Litterbags of both types were $25 \times 35 \mathrm{~cm}$ in size. This size allowed sufficient spread of litter inside the bags while also being small enough to easily transport and place in the field.

All litterbags contained five grams (range: 5.00 - $5.05 \mathrm{~g}$ ) of either honeysuckle or sugar maple leaf litter. Bags were then grouped into sets with each set comprised of all four possible mesh size/litter combinations. A total of three sets (12 bags) were placed in each plot during each incubation period. Sets were arranged in a grid pattern (bag order and position within the grid were randomized) and secured directly to the mineral soil surface using landscaping staples. Any surface leaf litter was removed from beneath the bag before attaching it to the soil. All sets were positioned at least 0.5 meter away from the plot edge and from any earthworm sampling locations. Litter bags were placed in the field on five separate dates (February 17th, May 16th, August 6th, and October 9th of 2012 and February 17th of 2013) and collections were made 46 days later. I originally 
planned to leave the bags in the field for three months; however, the rapid loss of honeysuckle litter from the large mesh bags prompted a shorter field incubation period. Three additional sets (12 bags) were taken into the field during the first collection period but never set out. These bags were returned to the lab and oven dried at $60^{\circ} \mathrm{C}$ for 48 hours to correct for air-dry to oven dry mass conversion and any mass lost due to handling.

At each collection date, litter bags were placed into individual paper bags in the field to prevent litter loss during transport. Because differences in mesh size could allow leaf fragments to be lost at a disproportionately higher rate from large-mesh bags, a visual inspection of the soil beneath each bag was made during collection. Any identifiable fragments were collected and bagged with the corresponding litterbag. Soil, roots, and other materials were removed from the leaf litter using clean KimWipes. Litter was oven dried at $60^{\circ} \mathrm{C}$ for 48 hours and weighed to determine mass lost. Percent mass lost was calculated by dividing the mass lost by the oven-dry-mass corrected starting weight.

\section{Environmental variables}

Air temperature at ground level, soil temperature at $10 \mathrm{~cm}$, and soil moisture content were measured at the beginning and end of each litterbag incubation period and at each earthworm collection date. Earthworm collections were performed in the middle of the litterbag incubation period (means at each earthworm collection in Table 2.3). To measure soil moisture content at each date, five $10 \mathrm{~cm}$-long soil cores were randomly collected from each 10x10 m plot using a $2 \mathrm{~cm}$ diameter soil corer. Because an aqueous solution was used to survey earthworm populations, soil cores were taken prior to 
earthworm collection to prevent subsurface flow from confounding the results. Soil cores were placed in plastic zip-lock bags and transported to the lab on ice. Within 24 hours of collection, soils were homogenized by hand and all visible plant, rock, and other debris materials were removed. Soil moisture was determined gravimetrically by oven drying $5.00 \mathrm{~g}$ of wet soil (range 5.00 to $5.05 \mathrm{~g}$ ) for 24 hours at $105^{\circ} \mathrm{C}$. After drying, samples were reweighed and soil moisture was calculated on a g water per g dry soil basis. Air temperature was measured $2-4 \mathrm{~cm}$ above soil surface and a soil temperature probe was used to measure temperature at $10 \mathrm{~cm}$. Three temperature readings were taken from randomly selected spots within each $10 \times 10 \mathrm{~m}$ plot and averaged. All temperature readings were taken immediately prior to earthworm collections. Depth to bedrock data were obtained from a USDA Natural Resources Conservation Service survey that was conducted in the plots in June 2009 (M. Carreiro, unpublished).

\section{Data Analysis}

To analyze adult worm populations, I used a combined ecological and taxonomic grouping system (Table 2.4), similar to the one described by Hale et al. (2005a). In some cases, worms could be identified to the species level, but Amynthas were reported at the genus level and Aporrectodea consisted of a species cluster that could not be separated. Juvenile worms are particularly difficult to distinguish at the species level and were combined into a single group called "juvenile”.

Earthworm biomass and density (total, adults only, and juvenile) were analyzed using mixed model repeated-measures (rm)-ANOVAs (PROC MIXED; SAS software 9.3, SAS Institute, Inc., Cary, NC). Honeysuckle shrub presence/removal, sampling 
month, and their interaction were modeled as fixed effects. Sampling month was treated as a fixed effect instead of a random effect in the model because I was interested in earthworm populations at those specific time points. Site $(n=8)$ was treated as a random effect and sampling month served as the repeated factor. Earthworms may have entered a state of aestivation during the hot, dry soil conditions present during the June collection (Hale et al. 2005a), resulting in an under-representative sample of the population. To account for this possibility and any effects it may have had on the model, an analysis that included June (date $n=5$ ) was run first followed by an analysis that excluded June (date $n=4)$. Data were tested for normality and equality of variance (PROC UNIVARIATE; SAS software 9.3) and $\log _{10}(\mathrm{x}+1)$ and square root transformations were applied to biomass and density data as necessary to satisfy model assumptions. Planned comparisons were made between honeysuckle present and removed plots at each date and between the March 2012 and March 2013 sampling dates to examine the responses of the worms to greatly contrasting winter month conditions in those two years.

Best-subset multiple regression analysis was used to determine the best linear regression model for total earthworm biomass at each date, using predictor variables described below. Total worm biomass was modeled at each date instead of across the entire year because the goal of this study was to determine the relative importance of different predictors during different seasons. As described earlier, only honeysuckle shrub present plots were used in this analysis as they had a wider range of densities and basal areas, and excluding removals allowed me to avoid including plots dominated by other exotic shrub species. An exploratory analysis of the data indicated that honeysuckle shrub basal area was a poor predictor of total earthworm biomass, so analyses focused on 
models using honeysuckle stem density. Stem density was included in every model as a predictor because one of the primary research questions for this aspect of the study was whether shrub abundance could explain the range of total earthworm biomass at each date. In addition to stem density, the following initial predictors were included in the model: soil temperature, soil moisture, and depth to bedrock. The best overall model was selected using the Akaike information criterion (AIC, Akaike 1973). Models with an AIC difference of less than 2 are considered to be indistinguishable (Burnham and Anderson 2002). In these cases, the Bayesian Information Criterion (BIC; Schwarz 1978) was used as a tie-breaker for model selection. Multicollinearity was initially checked by using PROC CORR (SAS software 9.3) to identify large bivariate correlations (Pearson's $r \geq$ 0.70) among pairs of predictor variables (Appendix 1). PROC REG (SAS software 9.3) was used to test predictor variables against each other and calculate variance inflation factors (VIF). VIFs that were $\leq 2.5$ indicated a lack of significant multicollinearity. After selecting the best overall regression model, each model was assessed for statistical significance $(p \leq 0.05)$.

The two main goals in regards to the litterbag experiment were to 1) determine the importance of L. maackii presence to litter macroinvertebrate activity, and 2) examine the activity of soil macroinvertebrates (including earthworms) in decaying litter across different seasons of the year. To answer the first goal, mass loss results from the litterbag experiment were analyzed using a rm-ANOVA (PROC MIXED; SAS software 9.3). Mean \% mass lost per plot was used as the dependent variable, and litter type, mesh bag size, honeysuckle presence/removal, and sampling date served as the main fixed effects. The initial full model included all possible interactions. After checking for the 
significance of the aforementioned interaction terms, I was able to reduce the final model to the stated fixed effects and the following interactions: mesh $\mathrm{x}$ litter, mesh $\mathrm{x}$ date, litter $\mathrm{x}$ date, and mesh $\mathrm{x}$ litter $\mathrm{x}$ date interaction. Site $(\mathrm{n}=8)$ was used as a random effect and sampling month $(\mathrm{n}=5)$ served as the repeated factor. I did not run a model excluding June from the analysis because the litterbag experiment was designed to test the amount of macroinvertebrate activity at different time points throughout the year. Three sets of planned comparisons were made for this analysis. The first set of planned comparisons examined differences between honeysuckle present and removed plots for bags of the same mesh size and same litter type within any one date. The second set of comparisons was between large and small mesh bags of the same litter type within the same plot type (honeysuckle present or removed) at any one date. The last set of comparisons was made between the two late winter to early spring sampling periods (February to April 2012 and 2013) while keeping all other explanatory variables constant (same mesh size, litter type, and plot type).

A second rm-ANOVA (PROC MIXED; SAS software 9.3) was run to examine the difference in mean percent litter mass loss between large mesh and small mesh bags. Because macroinvertebrates (including earthworms) were excluded from small mesh bags but allowed to access litter in the large mesh bags, the difference in mass loss between the two mesh sizes can be used as an indicator of the importance of soil macroinvertebrate activity to leaf litter decomposition. Differences in percent litter loss were calculated by subtracting the percent mass loss in the small mesh bags from the percent mass loss in large mesh bags within their respective block. Mean percent mass loss difference was used as the dependent variable while litter type, honeysuckle shrub 
presence/removal, and sampling date served as the main fixed effects. The initial full model included all possible interactions. After checking for the significance of the aforementioned interaction terms, the final model was reduced to the stated fixed effects and the litter $\mathrm{x}$ date interaction. Site $(\mathrm{n}=8)$ was treated as a random effect and sampling month $(\mathrm{n}=5)$ served as the repeated factor. Post-hoc comparisons were made between honeysuckle present and removed plots at each date and between all sampling dates for each litter type. To avoid the problem of finding significant differences due to multiple comparisons, the false discovery rate method (Benjamini and Hochberg 1995) was used (PROC MULTTEST; SAS software 9.3).

For all rm-ANOVAs, AIC values were used to determine the best-fit covariance structure for errors (Wang and Goonewardene 2004). As these analyses featured both REPEATED and RANDOM statements, the Kenward-Roger correction for denominator degrees of freedom (ddfm=KR) was used (Kenward and Roger 1997).

\section{$\underline{\text { Results }}$}

Two rm-ANOVAs (models with and without June 2012) were run for each measurement of earthworm biomass and density. Unless otherwise noted, the exclusion of the June 2012 collection date did not change the overall results of the models and all results presented below include June 2012 in the analyses. Table 2.5 summarizes the results from the repeated measures analysis of variance. Briefly, both the main effect of honeysuckle shrubs and the main effect of sampling date were found to be statistically significant for all earthworm biomass and density measured in this study. The shrub $\mathrm{x}$ date interaction was statistically significant for mean total density $(p=0.012)$ and mean 
juvenile density $(p=0.035)$ only. In terms of relative biomass, juveniles (range: $41.3 \%$ to 66.53\%), L. terrestris adults (range: $33.5 \%$ to 51.3\%), and Apporrectodea adults (range: $0.0 \%$ to $9.6 \%$ ) were the three most important groups at each date. Juveniles (range: $63.6 \%$ to $91.5 \%$ ), Apporrectodea adults (range: $0.00 \%$ to $22.2 \%$ ), and L. terrestris (range: $3.9 \%$ to $9.0 \%$ ) were also the three most important groups in terms of relative density (Table 2.6).

\section{Earthworm biomass}

Mean total worm biomass was $35.5 \%$ to $85.2 \%$ higher where honeysuckle was present depending on the date (Table 2.7). March $2012(p=0.0013)$ was the only collection date that displayed a statistically significant difference between honeysuckle present and honeysuckle removed plots (Fig. 2.2a), though a strong trend was observed in March $2013(p=0.055)$. Mean total biomass was statistically higher in March 2012 compared to March 2013 ( $p<0.0001)$ with honeysuckle present and honeysuckle removed plots having, respectively, 3.1 and 2.9 times more total biomass in March 2012. Similar patterns were observed for mean adult and mean juvenile worm biomass. Mean adult biomass was observed to be higher in honeysuckle shrub present plots across all sampling dates (Table 2.7), though March $2012(p=0.012)$ was the only date exhibiting a statistically significant difference between honeysuckle presence and removed comparisons (Fig. 2.2b). Statistically significant differences in mean adult biomass were observed between the two March collections ( $p<0.0001$ ), with March 2012 having 2.6 times higher mean adult biomass in both honeysuckle present and removal plots. Adult worms of each species were captured at each sample date except Amynthas, which was 
only captured during the September 2012 collection and only at two bottomland sites near Beargrass creek. Mean juvenile worm biomass was $33.7 \%$ to $78.4 \%$ higher where honeysuckle shrubs were present depending on the sampling date (Table 2.7). Honeysuckle present plots had statistically higher juvenile worm biomass in March $(p=0.013)$, September $(p=0.05)$, and November $(p=0.036)$ of 2012 compared to honeysuckle removal plots (Fig. 2.2c). Trends toward higher juvenile biomass in honeysuckle present plots were also observed in June $2012(p=0.093)$. Mean juvenile biomass was higher in March 2012 compared to March 2013 ( $p<0.0001$ ), with honeysuckle present and removal plots containing, respectively, 3.9 and 3.3 times higher juvenile biomass in March 2012.

\section{Earthworm density}

Over the entire course of the study, a total of 2,389 juvenile worms and 844 adult worms were collected from Cherokee Park. Adult grouping counts were represented as follows: 5 epigeic worms, 39 epi-endogeic worms, 580 endogeic worms, and 220 anecic worms. Aporrectodea caliginosa species complex was the most important taxon in the endogeic worm category (76.2\% of endogeic worms), followed by Octolasion tyrtaeum (16.0\% of endogeic worms) and Aporrectodea rosea ( $7.8 \%$ of endogeic worms). Otherwise, each of the remaining functional group categories reflected the abundance of a single species in that category. Namely, these were Amynthas ssp. in the epigeic grouping, Lumbricus rubellus in the endo-epigeic grouping, and L. terrestris in the anecic grouping. 
Mean total worm density was $13.8 \%$ to $66.0 \%$ higher in honeysuckle present plots than in honeysuckle removal plots across all sampling dates (Table 2.7). Mean total earthworm density was statistically higher in honeysuckle present plots in March 2012 ( $p<0.0001$; Fig. 2.2d). Trends towards higher densities in honeysuckle present plots were observed in September $2012(p=0.06)$ and November $2012(p=0.07)$. March 2012 differed significantly from March $2013(p<0.0001)$ in terms of mean total worm density. While honeysuckle present plots had 1.6 times higher mean total worm density in March 2012 compared to March 2013 ( $p<0.0001)$, no statistical differences were observed for honeysuckle removal plots $(p<0.18)$. Similar patterns were observed for mean adult and mean juvenile densities. Honeysuckle present plots had $36.8 \%$ to $125.0 \%$ higher adult worm densities depending on sampling dates (Table 2.7). Statistically higher adult densities were observed in honeysuckle present plots during March $(p<0.017)$ and September $(p<0.034)$ of 2012 (Fig. 2.2e), while honeysuckle present plots in March 2013 showed a trend $(p<0.073)$ towards higher adult density. Shrub present and shrub removal plots had 1.5 and 1.7 times higher mean adult densities in March 2012 compared to March 2013 ( $p<0.0001)$. Mean juvenile density only displayed statistically significant differences between honeysuckle present and removed plots in March $2012(p<0.0001$; Fig. 2.2f). Despite no significant differences, mean juvenile worm densities were always higher where honeysuckle shrubs were present (Table 2.7). An overall difference between March 2012 and March 2013 was not observed for mean juvenile biomass $(p<0.15)$; however, honeysuckle present plots had 1.3 times higher mean juvenile density in March 2012( $p<0.0032)$. No statistical difference between the two March sampling dates were observed for honeysuckle removed plots $(p<0.3144)$. 


\section{Litter loss and soil macroinvertebrate activity}

No soil macroinvertebrates were observed within small-mesh bags during the experiment, but millipedes, isopods, and spiders were occasionally observed in the largemesh bags. This suggests that small-mesh bags did exclude soil macroinvertebrates as intended. Percent litter mass loss differed significantly by mesh size $\left(F_{1,52.5}=256.91\right.$, $p<0.0001)$, litter type $\left(F_{1,52.5}=1354.53, p<0.0001\right)$, and sampling date $\left(F_{4,57}=12.26\right.$, $p<0.0001)$, but no difference was observed between honeysuckle present and removed plots $\left(F_{1,50.5}=1.84, p=0.1812\right)$. Among the interaction terms, the mesh $\mathrm{x}$ litter $\mathrm{x}$ date $\left(F_{4,57}=4.24, p=0.0045\right)$ and the litter $\mathrm{x}$ date $\left(F_{4,57}=10.48, p<0.0001\right)$ were significant but the mesh $\mathrm{x}$ litter $\left(F_{1,52.5}=1.49, p=0.23\right)$ and the mesh $\mathrm{x}$ date $\left(F_{4,57}=1.50, p=0.21\right)$ interactions were not. As expected due to its low lignin and high nitrogen content (Trammell et al. 2012), honeysuckle litter lost more mass than sugar maple for both mesh sizes at all dates during the study (Table 2.9). Honeysuckle mass loss from large-mesh bags was particularly rapid during the February17 to April 3, 2012 collection period (Fig. 2.3). By the end of the 46-day sampling period, large-mesh bags were completely devoid of honeysuckle litter, while small-mesh honeysuckle bags had lost only $52.1 \%$ of their litter. Percent mass loss differed between the late winter to early spring (February 17 to April 3) incubation periods of 2012 and 2013, though whether these differences were statistically significant depended on litter type and mesh size. Honeysuckle bags lost significantly more litter during the 2012 early spring incubation compared to the same period in 2013 for both large-mesh $(p<0.0004)$ and small-mesh $(p<0.014)$ bags. Conversely, large-mesh maple bags lost more mass in $2012(p<0.035)$ while small-mesh 
maple bags lost more in $2013(p<0.047)$. Mean total worm biomass was unable to predict litter mass loss for either litter type in the large-mesh bags using linear regressions.

Difference in mean percent litter mass loss between large-mesh and small-mesh bags were examined to determine the relative importance of soil macroinvertebrates to leaf litter decomposition at different time points throughout the year and as an index of macroinvertebrate activity seasonally (including earthworms). Percent litter mass loss differed significantly by litter type $\left(F_{1,142}=461.84, p<0.0001\right)$, date $\left(F_{4,142}=4.97\right.$, $p=0.0009)$, and the litter $\mathrm{x}$ date interaction $\left(F_{4,142}=2.78, p=0.026\right)$. Honeysuckle presence/removal was not found to be a significant predictor of macroinvertebrate activity $\left(F_{1,142}=1.98, p<0.16\right)$. As expected, soil macroinvertebrates showed a strong preference for honeysuckle litter across all sampling dates. On average, large-mesh bags lost between $31.1 \%$ and $54.3 \%$ more honeysuckle and $2.4 \%$ to $15.6 \%$ more sugar maple than small-mesh bags depending on the date (Fig. 2.4). Differences between large-mesh and small-mesh honeysuckle bags displayed no significant differences between plot type or dates. Conversely, differences between large-mesh and small-mesh sugar maple bags did display a date effect but patterns differed between honeysuckle present and removed plots. When comparison were made between honeysuckle present plots, March 2012 had a significantly larger difference in mean percent litter mass loss than June, September, or November of 2012. For honeysuckle removal plots, March 2012 displayed a significantly larger difference in mean percent litter mass loss compared to June 2012 and March 2013 (Fig. 2.4). No significant differences were observed between honeysuckle present and removed plots for sugar maple when correcting for multiple comparisons. 


\section{Environmental factors}

Air temperature was found to be highly correlated with soil temperature at several dates and was dropped from subsequent models (Appendix 1). Soil temperature and soil moisture were found to be moderately correlated (Pearson's $r=-0.64)$; however, they were retained in subsequent models because they were below the standard cutoff (Pearson's $r \geq 0.70$ ). Multiple regression analyses were conducted to examine the relationship between total earthworm biomass and honeysuckle stem density and other environmental variables at each date. Table 2.8 summarizes the best fit regression model for each date (see Appendix 2 for all models). Counter to expectations, stem density was only found to be a significant predictor of mean total biomass in March 2013. Unsurprisingly, soil temperature was an important predictor during the early and late summer (June 2012 and Sept 2012) and during the colder spring (March 2013). The models were able to account for between 12\% (Nov 2012) and 89\% (March 2013) of the variance in total worm biomass.

\section{$\underline{\text { Discussion }}$}

\section{Earthworm populations}

All earthworms collected during this study were non-native Eurasian species and no native species were found during any of the collections (Table 2.6). Kalisz and Wood (1995) offer a potential explanation for this finding; that native earthworm populations may decline and eventually disappear when physical disturbance and/or habitat fragmentation becomes severe. Invasive earthworm species are then able to colonize the empty habitat left behind by the extirpated native species, resulting in earthworm 
assemblies that are exclusively comprised of exotics. Cherokee Park, where this study was conducted, was originally established in 1891 from a consolidation of pastureland and fragmented woodlands (Levee 1992) and has a long history of both natural (e.g. an F4 tornado in 1974) and anthropogenic disturbances (Share 1976; Richardson 1974; Carreiro and Zipperer 2011). This history of disturbance may explain the exotic-only assemblages observed in this study.

Earthworm densities in this study were similar to those reported for exotic-only populations in second- and old-growth forests in Indiana (Gibson et al. 2013; range: 68-

91 worms $\mathrm{m}^{-2}$ ), for exotic-only populations in forested areas of south central New York (Suárez et al. 2006; range: 21.5 to 99.4 worms $\mathrm{m}^{-2}$ ), and for co-occurring native and exotic populations in eastern Kentucky (Kalisz and Dotson 1989; range: 2-112 worms m ${ }^{2}$ ). Smetak et al. (2007) also observed exotic-only earthworm assemblages in urban parks in Idaho, though their reported densities (437 individuals $\mathrm{m}^{-2}$ ) were much higher than those reported in this study. The species and structure of the earthworm assemblages observed in this Cherokee Park study closely resemble those reported in Gibson et al. (2013) for old-growth and second-growth forests in Indiana. While no historical surveys of earthworm populations exist for Cherokee Park, the dominance of endogeic and anecic species, combined with the near absence of epigeic earthworms, indicates that the park is in the later stages of invasion.

\section{Shrubs effects on earthworm populations}

Earthworm biomass and density were higher in honeysuckle present plots compared to honeysuckle removed plots across all sampling dates, but the size of the 
shrub effect varied by seasons. There are at least two mechanisms that could account for the differences between honeysuckle present and removed plots observed in this study: high quality leaf litter inputs from honeysuckle shrubs, and/or alteration of the soil microclimate. Invasive earthworms are known to prefer litter with a low C:N ratio and low phenolic content (Hendriksen 1990; Schönholzer et al. 1998; Curry and Schmidt 2007) and L. maackii produces large quantities of leaf litter that has a lower C:N, percent lignin, lignin: $\mathrm{N}$ ratio, and LCI than co-occurring native litters so far examined (Poulette and Arthur 2012; Trammell et al. 2012). While my experimental design did not explicitly separate the effects of litter input versus changes in soil temperature, worm biomass and density were highest during the March 2012 and March 2013 sampling dates (Fig 2.2). Soil macroinvertebrates (including earthworms) were found to be relatively active in decaying litter during this time period (Fig 2.4) and strong preferences for honeysuckle over sugar maple were detected (Fig 2.3). However, rapid and selective consumption of honeysuckle litter by macroinvertebrates early in the year results in its absence from the forest floor for much of the summer and fall (Pipal, personal observation). Furthermore, leaf litter mass in this woodland has mostly decayed by mid-summer and the percent bare soil is high (M. Carreiro, unpublished). Therefore, litter inputs from honeysuckle in midto late December may boost earthworm populations by early spring, but the relative importance of honeysuckle litter may decline as it is removed from the forest floor. Instead, changes in soil microclimate due to the heavy shade provided by L. maackii shrubs may become more important during the summer. Though not statistical significant, honeysuckle present plots in June and September of 2012 did have higher mean worm biomass and density. Soil temperature at $10 \mathrm{~cm}$ was $0.6^{\circ} \mathrm{C}$ and $1.1^{\circ} \mathrm{C}$ cooler, 
respectively, during these months in honeysuckle present plots. This suggests that changes in microclimate due to shrub shading may become more important to worm survivorship when the leaf layer has been depleted, though the size of the effect may be smaller than the effect from litter inputs.

Multiple regression analysis did not find a honeysuckle density effect on earthworm biomass or density. Instead, soil temperature was found to be the most important regressor in explaining earthworm biomass and density. The lack of a honeysuckle density effect may have stemmed from the relatively low number of sites used in this study $(n=8)$. Alternatively, density effects from honeysuckle shrubs may be limited above certain thresholds due to reallocation of resources to shoot growth instead of leaf production. For example, if shrubs in high density sites allocate more resources to shoot growth versus leaf production (i.e. outgrow competing shrubs), then litter inputs may not be significantly higher than leaf litter inputs in a medium density plot. Thus, there may not have been enough low density sites in this study to resolve a honeysuckle density effect on worm populations.

Other studies have observed higher earthworm population densities in sites colonized by invasive plants. Kourtev et al. (1999) found that sites invaded by Japanese barberry (Berberis thunbergii) and Japanese stiltgrass (Microstegium vimineum) had higher earthworm densities compared to uninvaded sites in three northern New Jersey parks. Heneghan et al. (2007) reported higher total worm biomass and densities in areas dominated by common buckthorn (Rhamnus cathartica) compared to other woodland communities in forests near Chicago, IL. Madritch and Lindroth (2009) observed that the removal of common buckthorn and Bell's honeysuckle (Lonicera x bella) from a 
hardwood forest in Wisconsin significantly reduced exotic earthworm biomass and density. However, all of these studies were conducted in regions whose native earthworm populations were extirpated by the Pleistocene glaciations (Gates 1977). To my knowledge, no other studies have examined relationships between exotic earthworms and invasive plants in areas where native worm species may also be present. Furthermore, this study also explored the dynamics of the invasive plant-worm relationship across different seasons of the year instead of at a single time point.

It is possible that the shrub treatment effect was not due to the identity of the shrub per se but simply one of biomass removal, without compensatory contributions from growth of other plants since shrub removal. I find this explanation unlikely for three reasons. First, the native understory found in uninvaded eastern deciduous forests is significantly different than the understory that results from L. maackii invasion. The native understories of eastern deciduous forests are relatively open, lack abundant native shrub cover, and are composed primarily of hardwood saplings with a dense herbaceous and seedling layer (Collier et al 2002; Madritch and Lindroth 2009). Conversely, $L$. maackii invasion tends to lead to the development of a dense, homogenous shrub layer with a virtually non-existent herb and seedling layer (Hutchinson and Vankat 1997; Collier et al 2002). Forests invaded by L. maackii tend to have significantly higher understory biomass than uninvaded forests (Luken 1988). Second, the dense shrub thickets formed by L. maackii may act as a barrier to canopy leaf litter (McNeish et al 2014), redirecting litter inputs from trees to areas where shrubs were absent or removed. Leaf senescence in native tree species tends to occur between late September to early November while senescence in L. maackii shrubs does not occur until mid to late 
December. Thus, L. maackii litter may be compensating for a decrease in canopy litter inputs rather simply adding to the total litter input for the system, and therefore it is the quality of the honeysuckle litter that makes the difference. Lastly, the leaf litter chemistry between L. maackii and native tree species differ in quality (Trammell et al. 2012). Even though tree species may display shifts in $\mathrm{C}: \mathrm{N}$ ratios and defensive compounds as they age (Boege and Marquis 2005), it is unlikely that these differences would be as large or as pronounced as the difference between the litter of native trees and honeysuckle in this forest system (Madritch and Lindroth 2009).

\section{Importance of macroinvertebrates to leaf litter decay}

As has been reported in other studies, the activity of earthworms and other soil macroinvertebrates can greatly enhance the decomposition of leaf litter (Pouyat and Carreiro 2003; Suárez et al. 2006; Heneghan et al. 2007; Holdsworth et al. 2008). Because the experimental design did not allow me to separate the effects of earthworms versus other soil macroinvertebrate detriovores, I attribute patterns of leaf litter decay in the large mesh bags to "soil macroinvertebrates". However, these patterns are likely due to exotic earthworms given the overall size of the earthworm population and that other macroinvertebrates were seldom observed in the litter layer or in the litter bags. In this study, large-mesh litterbags that allowed macroinvertebrates access to leaf litter lost significantly more honeysuckle and sugar maple litter than small-mesh litterbags that excluded them (Fig 2.3). However, no statistically significant differences were observed between honeysuckle present and honeysuckle removed plots at any particular date. Instead, the size of potential macroinvertebrate contributions to leaf litter decomposition 
depended on litter type and season. Soil macroinvertebrates displayed a strong preference for honeysuckle litter over the more recalcitrant sugar maple, and decay of honeysuckle litter by macroinvertebrates was consistently high across all seasons (Fig 2.4.). Conversely, macroinvertebrate decay of sugar maple litter was highest in March 2012 and lower during the remaining months of the study (Fig 2.4.). These results suggest that macroinvertebrates are active in decaying leaf litter throughout the year, including during the late winter to early spring period when honeysuckle litter is present in the leaf litter layer. While honeysuckle shrubs do not appear to directly influence macroinvertebrate feeding activity levels, soil macroinvertebrates did display a strong preference for honeysuckle over a native tree litter.

It should be noted that my litterbag experiment was standardized by using fresh litter at the start of each sampling period. This allowed for comparisons of activity levels between seasons without the confounding effects of time and differences in litter quality. However, it is likely that the fresh litter in the bags differed from litter in the surrounding leaf litter layer in terms of palatability. Fresh honeysuckle may have been a highly attractive food source for macroinvertebrates during the summer and early fall when high quality litter was scarce. Unlike other studies (Suárez et al 2006; Heneghan et al. 2007), I did not observe any relationships between mean total worm biomass and leaf litter loss. This result may be attributable to the relatively low number of sites used in this study $(n=8)$ or due to our sampling technique. Because the litterbags contained fresh litter each time they were set out, our single collection incubation design may have been too short to detect earthworm effects on the less palatable sugar maple litter and too long to detect an effect on the highly palatable honeysuckle litter. 


\section{Invasional Meltdown and Climate Change}

Full invasional meltdown requires mutual facilitation between invasives that leads to either an increase in the number of introductions and/or impacts of invasion (Simberloff 2006). The results presented in this study suggest that a positive feedback loop may exist between invasive earthworms and invasive L. maackii shrubs, potentially resulting in invasional meltdown (Fig 2.1). Invasive shrub honeysuckles may promote exotic earthworms by providing large quantities of high quality honeysuckle litter during the late winter to early spring and cooler soil temperatures beneath shrubs during the summer and fall. Exotic earthworms may potentially facilitate honeysuckle shrubs in two ways. First, earthworms can rapidly reduce the forest litter layer (Bohlen et al 2004b), creating the bare soil conditions that favor the growth and establishment of honeysuckle seedlings (Bartuszevige et al. 2007; Wilson et al. 2013). Second, decay of honeysuckle litter by exotic earthworms may create a pulse of nitrogen during the late winter to early spring that only honeysuckle shrubs are able to exploit. A con-current study conducted in the late winter to early spring period of 2013 found that large mesh honeysuckle bags had $59.4 \%$ less $\mathrm{N}$ remaining than small mesh honeysuckle bags (Chapter 2). Because earthworms are known to have very low nitrogen assimilation efficiencies (Edwards and Bohlen 1996; Whalen and Parmelee 1999), large amounts of nitrogen consumed in the leaf litter may end up in worm castings. These castings can greatly enhance soil microbial activity and $\mathrm{N}$ mineralization rates (Burtelow et al. 1998; Zhu and Carreiro 2004), potentially creating large pools of labile nitrogen during the late winter to early spring. As bud break for L. maackii in the Louisville region tends to occur earlier in the spring than woody natives (February to early March for L. maackii; April for native shrubs and 
trees), these shrubs may be one of the only plants positioned to take advantage of the increased nitrogen pool created by invasive earthworms during the late winter to early spring.

Climate change may also play an important role in determining the strength of the interactions within the invasional meltdown model. This study found that the late winter to early spring (February 17th to April 3rd) period of 2012 had statistically higher earthworm biomass, earthworm density, and mass loss for honeysuckle compared to the same time period in 2013. These differences may be attributable to the warmer winter conditions of 2012, which may have allowed earthworm populations to reproduce and remain active throughout the winter. More active earthworm populations during the winter months may also lead to a shift in the timing of when nutrients become available. If native woody plants cannot alter their bud break to match these shifts, then invasive plants with extended leaf phenologies may stand to receive an even greater benefit from the activity of exotic earthworms. However, if invasive honeysuckle shrubs are also unable to make use of the majority of these early season nitrogen pools, then nitrogen exports from the system may increase. These losses may be further exacerbated by honeysuckle itself, which tends to limit native spring ephemeral herb cover via shading and other mechanisms. As such, honeysuckle may limit the potential of native spring ephemeral herb to serve as a "vernal dam" for nutrients like inorganic nitrogen (Muller and Bormann 1976; Tessier and Raynal 2003). In these cases, total nitrogen availability for native shrub and tree species may be reduced and terrestrial nitrogen inputs to aquatic systems may increase. 


\section{Conclusions}

The combined impacts of invasive earthworms, honeysuckle, and climate change could have serious implications for the nitrogen cycling and future production rates of forests. The results of this experiment demonstrate that interactions between exotic earthworms and invasive shrub honeysuckle may fit the model of invasional meltdown. The biomass and density of invasive earthworm populations was found to be higher in the presence of $L$. maackii, most likely through the addition of large quantities of high quality litter or by modulation of soil temperature. Invasive earthworms may facilitate the growth and spread of $L$. maackii by creating the bare soil conditions that favor honeysuckle establishment or by increasing soil nitrogen availability during a time of the year when mainly shrub honeysuckles can exploit it. Our results suggest that managers may be able to reduce the size of exotic earthworm populations by removing invasive honeysuckle shrubs. However, if honeysuckle shrubs are the only woody plants capable of utilizing the early spring nitrogen pool created by invasive earthworms, these systems could be at risk for increased nitrogen loss following shrub removal. Therefore, I recommend that managers actively plant native spring ephemerals following honeysuckle removal to minimize the potential for nitrogen losses from the system. 
Table 2.1. Earthworm study site locations. $\mathrm{H}=$ honeysuckle shrubs present, $\mathrm{R}=$ honeysuckle shrubs removed. Stem density is expressed as living stems (>1 m height) per hectare, while basal area is expressed as $\mathrm{m}^{2}$ per hectare. The "exotic shrub" category includes all exotic shrubs except shrub honeysuckle.

\begin{tabular}{|c|c|c|c|c|c|c|c|c|c|}
\hline Site & $\begin{array}{l}\text { Coordinates } \\
\text { (dd) }\end{array}$ & $\begin{array}{l}\text { Depth to } \\
\text { Bedrock } \\
\quad(\mathrm{cm})\end{array}$ & $\begin{array}{c}\text { Honeysuckle } \\
\text { Stem Density } \\
\text { (\# / ha) }\end{array}$ & $\begin{array}{c}\text { Honeysuckle } \\
\text { Basal Area } \\
\left(\mathrm{m}^{2} / \mathrm{ha}\right)\end{array}$ & $\begin{array}{c}\text { Exotic Shrub } \\
\text { Stem Density } \\
(\# / \text { ha })\end{array}$ & $\begin{array}{c}\text { Exotic Shrub } \\
\text { Basal Area } \\
\left(\mathrm{m}^{2} / \mathrm{ha}\right)\end{array}$ & $\begin{array}{c}\text { Native Shrub } \\
\text { Stem Density } \\
\text { (\# / ha) }\end{array}$ & $\begin{array}{c}\text { Native Shrub } \\
\text { Basal Area } \\
\left(\mathrm{m}^{2} / \mathrm{ha}\right)\end{array}$ & $\begin{array}{c}\text { Aspect } \\
\left(0^{\circ}=\text { North }\right)\end{array}$ \\
\hline $1-\mathrm{H}$ & $38.240 ;-85.697$ & $>122$ & 4500 & 1.95 & 700 & 0.14 & 1200 & 0.19 & $\operatorname{NW}\left(332^{\circ}\right)$ \\
\hline $1-\mathrm{R}$ & $38.240 ;-85.697$ & $>122$ & 1000 & 0.04 & 0 & 0.00 & 0 & 0.00 & $\operatorname{NW}\left(334^{\circ}\right)$ \\
\hline $2-\mathrm{H}$ & $38.243 ;-85.700$ & 87 & 10700 & 7.98 & 0 & 0.00 & 0 & 0.00 & $\mathrm{~S}\left(158^{\circ}\right)$ \\
\hline $2-\mathrm{R}$ & $38.243 ;-85.700$ & 87 & 700 & 0.10 & 0 & 0.00 & 0 & 0.00 & $\operatorname{SE}\left(148^{\circ}\right)$ \\
\hline $3-\mathrm{H}$ & $38.245 ;-85.696$ & $>122$ & 14100 & 6.15 & 500 & 0.05 & 0 & 0.00 & $\mathrm{~W}\left(271^{\circ}\right)$ \\
\hline $3-\mathrm{R}$ & $38.245 ;-85.696$ & $>122$ & 3200 & 0.12 & 500 & 0.06 & 0 & 0.00 & $\mathrm{~W}\left(271^{\circ}\right)$ \\
\hline $4-\mathrm{H}$ & $38.242 ;-85.696$ & 92 & 12800 & 8.15 & 0 & 0.00 & 0 & 0.00 & $\operatorname{SE}\left(149^{\circ}\right)$ \\
\hline $4-\mathrm{R}$ & $38.242 ;-85.696$ & 92 & 100 & 0.00 & 200 & 0.07 & 0 & 0.00 & $\mathrm{~S}\left(158^{\circ}\right)$ \\
\hline $5-\mathrm{H}$ & $38.241 ;-85.696$ & 56 & 8100 & 3.06 & 1900 & 0.31 & 0 & 0.00 & $\mathrm{E}\left(105^{\circ}\right)$ \\
\hline $5-\mathrm{R}$ & $38.241 ;-85.696$ & $>122$ & 1600 & 0.03 & 0 & 0.00 & 2800 & 0.06 & $\mathrm{E}\left(101^{\circ}\right)$ \\
\hline $6-\mathrm{H}$ & $38.240 ;-85.694$ & $>122$ & 14400 & 2.93 & 3900 & 0.50 & 0 & 0.00 & $\mathrm{~W}\left(252^{\circ}\right)$ \\
\hline $6-\mathrm{R}$ & $38.240 ;-85.694$ & $>122$ & 1700 & 0.07 & 30500 & 1.84 & 0 & 0.00 & $\mathrm{~W}\left(277^{\circ}\right)$ \\
\hline $7-\mathrm{H}$ & $38.241 ;-85.693$ & 67 & 9600 & 5.02 & 1100 & 0.22 & 0 & 0.00 & $\mathrm{~S}\left(162^{\circ}\right)$ \\
\hline $7-\mathrm{R}$ & $38.241 ;-85.693$ & 67 & 1200 & 0.05 & 8800 & 0.22 & 0 & 0.00 & $S\left(162^{\circ}\right)$ \\
\hline $8-\mathrm{H}$ & $38.234 ;-85.684$ & 58 & 17700 & 8.38 & 0 & 0.00 & 0 & 0.00 & $\mathrm{~W}\left(259^{\circ}\right)$ \\
\hline 8-R & $38.234 ;-85.684$ & 58 & 1200 & 0.18 & 0 & 0.00 & 0 & 0.00 & $\mathrm{~W}\left(253^{\circ}\right)$ \\
\hline
\end{tabular}


Table 2.2. Mean monthly air temperatures and total monthly precipitation levels for the winter months preceding the March 2012 and the March 2013 sampling periods. Mean air temperature at the Louisville International Airport was obtained from the National Climate Data Center (NCDC 2011, 2012, and 2013). Total monthly precipitation data at the Nightingale telemetered site (closest monitored rain gauge to these sites) was obtained from Louisville/Jefferson County Metropolitan Sewer District Rainfall Query (2014). Normal values were obtained from the National Climate Data Center (NCDC 2011, 2012, and 2013) and represent the average air temperature and average total monthly precipitation from 1971 to 2000.

\begin{tabular}{|c|c|c|c|c|c|c|c|c|c|c|c|c|c|}
\hline \multicolumn{7}{|c|}{ Winter 2012} & \multicolumn{7}{|c|}{ Winter 2013} \\
\hline Month & $\begin{array}{l}\text { Temp } \\
\left({ }^{\circ} \mathrm{C}\right)\end{array}$ & $\begin{array}{c}\text { Normal } \\
\left({ }^{\circ} \mathrm{C}\right)\end{array}$ & $\begin{array}{c}\text { Departure } \\
\left({ }^{\circ} \mathrm{C}\right)\end{array}$ & $\begin{array}{l}\text { Precip } \\
(\mathrm{cm})\end{array}$ & $\begin{array}{l}\text { Normal } \\
(\mathrm{cm})\end{array}$ & $\begin{array}{l}\text { Departure } \\
(\mathrm{cm})\end{array}$ & Month & $\begin{array}{l}\text { Temp } \\
\left({ }^{\circ} \mathrm{C}\right)\end{array}$ & $\begin{array}{l}\text { Normal } \\
\left({ }^{\circ} \mathrm{C}\right)\end{array}$ & $\begin{array}{c}\text { Departure } \\
\left({ }^{\circ} \mathrm{C}\right)\end{array}$ & $\begin{array}{l}\text { Precip } \\
(\mathrm{cm})\end{array}$ & $\begin{array}{l}\text { Normal } \\
(\mathrm{cm})\end{array}$ & $\begin{array}{l}\text { Departure } \\
\quad(\mathrm{cm})\end{array}$ \\
\hline $\begin{array}{l}\text { Dec } \\
2011\end{array}$ & 6.1 & 3.3 & +2.8 & 14.20 & 9.37 & +4.83 & $\begin{array}{c}\text { Dec } \\
2012\end{array}$ & 6.9 & 3.3 & +3.6 & 16.15 & 9.37 & +6.78 \\
\hline $\begin{array}{c}\text { Jan } \\
2012\end{array}$ & 4.0 & 0.6 & +3.4 & 9.47 & 8.23 & +1.24 & $\begin{array}{c}\text { Jan } \\
2013\end{array}$ & 3.3 & 0.6 & +2.7 & 12.27 & 8.23 & +4.04 \\
\hline $\begin{array}{l}\text { Mar } \\
2012\end{array}$ & 15.3 & 8.3 & +7.0 & 14.33 & 10.59 & +3.74 & $\begin{array}{l}\text { Mar } \\
2013\end{array}$ & 5.1 & 8.3 & -3.2 & 11.02 & 10.59 & +0.43 \\
\hline
\end{tabular}


Table 2.3. Mean air temperature at ground level, mean soil temperature at $10 \mathrm{~cm}$, and mean soil moisture in the top $10 \mathrm{~cm}$ of soil at each earthworm collection date. Values are means; parentheses enclose standard errors $(\mathrm{n}=8$ sites per date). Five pooled samples were used to calculate gravimetric soil moisture means (g water per g oven dry mass soil). Three samples were used to calculate means for air temperature and soil temperature at $10 \mathrm{~cm}$.

\begin{tabular}{|c|c|c|c|c|c|c|c|c|c|c|c|c|c|c|c|}
\hline & \multicolumn{3}{|c|}{ March 2012} & \multicolumn{3}{|c|}{ June 2012} & \multicolumn{3}{|c|}{ September 2012} & \multicolumn{3}{|c|}{ November 2012} & \multicolumn{3}{|c|}{ March 2013} \\
\hline & $\begin{array}{c}\text { Air } \\
\text { Temp } \\
\left({ }^{\circ} \mathrm{C}\right)\end{array}$ & $\begin{array}{c}\text { Soil } \\
\text { Temp } \\
\left({ }^{\circ} \mathrm{C}\right)\end{array}$ & $\begin{array}{c}\text { Soil } \\
\text { Water } \\
(\mathrm{g})\end{array}$ & $\begin{array}{c}\text { Air } \\
\text { Temp } \\
\left({ }^{\circ} \mathrm{C}\right)\end{array}$ & $\begin{array}{c}\text { Soil } \\
\text { Temp } \\
\left({ }^{\circ} \mathrm{C}\right)\end{array}$ & $\begin{array}{c}\text { Soil } \\
\text { Water } \\
(\mathrm{g})\end{array}$ & $\begin{array}{c}\text { Air } \\
\text { Temp } \\
\left({ }^{\circ} \mathrm{C}\right)\end{array}$ & $\begin{array}{c}\text { Soil } \\
\text { Temp } \\
\left({ }^{\circ} \mathrm{C}\right)\end{array}$ & $\begin{array}{c}\text { Soil } \\
\text { Water } \\
(\mathrm{g})\end{array}$ & $\begin{array}{c}\text { Air } \\
\text { Temp } \\
\left({ }^{\circ} \mathrm{C}\right)\end{array}$ & $\begin{array}{c}\text { Soil } \\
\text { Temp } \\
\left({ }^{\circ} \mathrm{C}\right)\end{array}$ & $\begin{array}{c}\text { Soil } \\
\text { Water } \\
(\mathrm{g})\end{array}$ & $\begin{array}{c}\text { Air } \\
\text { Temp } \\
\left({ }^{\circ} \mathrm{C}\right)\end{array}$ & $\begin{array}{c}\text { Soil } \\
\text { Temp } \\
\left({ }^{\circ} \mathrm{C}\right)\end{array}$ & $\begin{array}{c}\text { Soil } \\
\text { Water } \\
(\mathrm{g})\end{array}$ \\
\hline $\begin{array}{l}\text { Grand } \\
\text { Mean }\end{array}$ & $\begin{array}{c}19.0 \\
(0.44)\end{array}$ & $\begin{array}{c}12.7 \\
(0.35)\end{array}$ & $\begin{array}{c}0.48 \\
(0.017)\end{array}$ & $\begin{array}{c}27.9 \\
(0.31)\end{array}$ & $\begin{array}{c}22.3 \\
(0.17)\end{array}$ & $\begin{array}{c}0.17 \\
(0.012)\end{array}$ & $\begin{array}{c}25.8 \\
(0.358)\end{array}$ & $\begin{array}{c}21.4 \\
(0.30)\end{array}$ & $\begin{array}{c}0.24 \\
(0.011)\end{array}$ & $\begin{array}{c}12.9 \\
(0.49)\end{array}$ & $\begin{array}{c}11.0 \\
(0.30)\end{array}$ & $\begin{array}{c}0.43 \\
(0.011)\end{array}$ & $\begin{array}{c}2.6 \\
(0.25)\end{array}$ & $\begin{array}{c}4.4 \\
(0.22)\end{array}$ & $\begin{array}{c}0.35 \\
(0.020)\end{array}$ \\
\hline $\begin{array}{l}\text { Shrubs } \\
\text { present }\end{array}$ & $\begin{array}{c}18.0 \\
(0.49)\end{array}$ & $\begin{array}{c}11.7 \\
(0.31)\end{array}$ & $\begin{array}{c}0.49 \\
(0.025)\end{array}$ & $\begin{array}{c}27.3 \\
(0.43)\end{array}$ & $\begin{array}{c}22.0 \\
(0.24)\end{array}$ & $\begin{array}{c}0.18 \\
(0.020)\end{array}$ & $\begin{array}{c}25.0 \\
(0.234)\end{array}$ & $\begin{array}{c}20.9 \\
(0.25)\end{array}$ & $\begin{array}{c}0.24 \\
(0.018)\end{array}$ & $\begin{array}{c}12.2 \\
(0.57)\end{array}$ & $\begin{array}{c}10.8 \\
(0.37)\end{array}$ & $\begin{array}{c}0.43 \\
(0.018)\end{array}$ & $\begin{array}{c}2.5 \\
(0.30)\end{array}$ & $\begin{array}{c}4.2 \\
(0.27)\end{array}$ & $\begin{array}{c}0.36 \\
(0.027)\end{array}$ \\
\hline $\begin{array}{l}\text { Shrubs } \\
\text { removed }\end{array}$ & $\begin{array}{c}20.1 \\
(0.52)\end{array}$ & $\begin{array}{c}13.7 \\
(0.35)\end{array}$ & $\begin{array}{c}0.47 \\
(0.025)\end{array}$ & $\begin{array}{c}28.5 \\
(0.34)\end{array}$ & $\begin{array}{c}22.6 \\
(0.20)\end{array}$ & $\begin{array}{c}0.16 \\
(0.015)\end{array}$ & $\begin{array}{c}26.6 \\
(0.547)\end{array}$ & $\begin{array}{c}22.0 \\
(0.49)\end{array}$ & $\begin{array}{c}0.23 \\
(0.015)\end{array}$ & $\begin{array}{c}13.6 \\
(0.76)\end{array}$ & $\begin{array}{c}11.3 \\
(0.47)\end{array}$ & $\begin{array}{c}0.43 \\
(0.014)\end{array}$ & $\begin{array}{c}2.7 \\
(0.42)\end{array}$ & $\begin{array}{c}4.6 \\
(0.35)\end{array}$ & $\begin{array}{c}0.34 \\
(0.031)\end{array}$ \\
\hline
\end{tabular}


Table 2.4. Earthworm taxa and the juvenile demographic group used in all analyses.

\begin{tabular}{lll}
\hline \hline Grouping & Ecological Grouping & Species included \\
\hline Amynthas & epigeic & Amynthas spp \\
Lumbricus rubellus & epi-endogeic & L. rubellus \\
Aporrectodea & endogeic & A. caliginosa species complex, A. rosea \\
Octolasion & endogeic & O. tyrtaeum \\
Lumbricus terrestris & anecic & L. terrestris \\
Juveniles & all & all \\
\hline \hline
\end{tabular}


Table 2.5. Repeated measures analysis of variance results for earthworm biomass and density data. Shrub presence, sampling date, and their interaction served as fixed factors. The degrees of freedom for each F statistic are listed.

\begin{tabular}{|c|c|c|c|c|c|c|}
\hline & \multicolumn{2}{|c|}{ Shrubs } & \multicolumn{2}{|c|}{ Date } & \multicolumn{2}{|c|}{ Shrubs x Date } \\
\hline & $\mathrm{F}_{1,63}$ & $\mathrm{p}$-value & $\mathrm{F}_{4,63}$ & p-value & $\mathrm{F}_{4,63}$ & p-value \\
\hline Mean total biomass & 20.37 & $<0.0001$ & 54.09 & $<0.0001$ & 0.70 & 0.60 \\
\hline Mean adult biomass & 10.45 & 0.0020 & 37.27 & $<0.0001$ & 0.57 & 0.68 \\
\hline Mean juvenile biomass & 17.06 & 0.0001 & 42.06 & $<0.0001$ & 0.41 & 0.80 \\
\hline Mean total density & 25.80 & $<0.0001$ & 73.89 & $<0.0001$ & 3.51 & 0.012 \\
\hline Mean adult density & 15.90 & 0.0002 & 52.49 & $<0.0001$ & 0.30 & 0.87 \\
\hline Mean juvenile density & 17.21 & 0.0001 & 63.47 & $<0.0001$ & 2.76 & 0.035 \\
\hline
\end{tabular}


Table 2.6. Effects of L. maackii on adult worm species. Biomass is presented as g oven dried worm mass per $\mathrm{m}^{2}$. Density is given as the number of individuals per $\mathrm{m}^{2}$. Values are means $(\mathrm{n}=8$ plots per treatment); parentheses enclose standard errors. Asterisks indicate a significant difference $(*: p \leq 0.05)$ between shrub present and shrub removed plots for any single date, according to analyses of variance. Different letters indicates a strong trend $(0.05 \leq p \leq 0.10)$ between shrub present and shrub removed plots for any single date, according to ANOVA.

\begin{tabular}{|c|c|c|c|c|c|c|c|c|c|c|}
\hline & \multicolumn{2}{|c|}{ Mar 2012} & \multicolumn{2}{|c|}{ June 2012} & \multicolumn{2}{|c|}{ Sept 2012} & \multicolumn{2}{|c|}{ Nov 2012} & \multicolumn{2}{|c|}{ Mar 2013} \\
\hline & $\begin{array}{l}\text { Shrubs } \\
\text { Present }\end{array}$ & $\begin{array}{l}\text { Shrubs } \\
\text { Removed }\end{array}$ & $\begin{array}{l}\text { Shrubs } \\
\text { Present }\end{array}$ & $\begin{array}{l}\text { Shrubs } \\
\text { Removed }\end{array}$ & $\begin{array}{l}\text { Shrubs } \\
\text { Present }\end{array}$ & $\begin{array}{l}\text { Shrubs } \\
\text { Removed }\end{array}$ & $\begin{array}{l}\text { Shrubs } \\
\text { Present }\end{array}$ & $\begin{array}{l}\text { Shrubs } \\
\text { Removed }\end{array}$ & $\begin{array}{l}\text { Shrubs } \\
\text { Present }\end{array}$ & $\begin{array}{c}\text { Shrubs } \\
\text { Removed }\end{array}$ \\
\hline \multicolumn{11}{|l|}{ Biomass } \\
\hline Amynthas & $\begin{array}{c}0.0 \\
(0.00)\end{array}$ & $\begin{array}{c}0.0 \\
(0.00)\end{array}$ & $\begin{array}{c}0.0 \\
(0.00)\end{array}$ & $\begin{array}{c}0.0 \\
(0.00)\end{array}$ & $\begin{array}{c}0.0 \\
(0.01)\end{array}$ & $\begin{array}{c}0.0 \\
(0.01)\end{array}$ & $\begin{array}{c}0.0 \\
(0.00)\end{array}$ & $\begin{array}{c}0.0 \\
(0.00)\end{array}$ & $\begin{array}{c}0.0 \\
(0.00)\end{array}$ & $\begin{array}{c}0.0 \\
(0.00)\end{array}$ \\
\hline L. rubellus & $\begin{array}{c}0.1 \\
(0.04)\end{array}$ & $\begin{array}{c}0.1 \\
(0.04)\end{array}$ & $\begin{array}{c}0.0 \\
(0.01)\end{array}$ & $\begin{array}{c}0.0 \\
(0.00)\end{array}$ & $\begin{array}{c}0.0 \\
(0.01)\end{array}$ & $\begin{array}{c}0.0 \\
(0.01)\end{array}$ & $\begin{array}{c}0.0 \\
(0.01)\end{array}$ & $\begin{array}{c}0.0 \\
(0.03)\end{array}$ & $\begin{array}{c}0.0 \\
(0.01)\end{array}$ & $\begin{array}{c}0.0 \\
(0.01)\end{array}$ \\
\hline Aporrectodea & $\begin{array}{c}1.5 \\
(0.30)\end{array}$ & $\begin{array}{c}0.9 \\
(0.16)\end{array}$ & $\begin{array}{c}0.0 \\
(0.01)\end{array}$ & $\begin{array}{c}0.0 \\
(0.00)\end{array}$ & $\begin{array}{c}0.5^{\mathrm{a}} \\
(0.09)\end{array}$ & $\begin{array}{c}0.3^{b} \\
(0.06)\end{array}$ & $\begin{array}{c}0.7 \\
(0.25)\end{array}$ & $\begin{array}{c}0.4 \\
(0.12)\end{array}$ & $\begin{array}{c}0.4 \\
(0.11)\end{array}$ & $\begin{array}{c}0.2 \\
(0.07)\end{array}$ \\
\hline Octolasion & $\begin{array}{c}0.1 \\
(0.03)\end{array}$ & $\begin{array}{c}0.1 \\
(0.02)\end{array}$ & $\begin{array}{c}0.0 \\
(0.00)\end{array}$ & $\begin{array}{c}0.0 \\
(0.00)\end{array}$ & $\begin{array}{c}0.1 \\
(0.02)\end{array}$ & $\begin{array}{c}0.1 \\
(0.01)\end{array}$ & $\begin{array}{c}0.1 \\
(0.03)\end{array}$ & $\begin{array}{c}0.1 \\
(0.02)\end{array}$ & $\begin{array}{c}0.0 \\
(0.01)\end{array}$ & $\begin{array}{c}0.0 \\
(0.01)\end{array}$ \\
\hline L. terrestris & $\begin{array}{c}7.8^{\mathrm{a}} \\
(1.19)\end{array}$ & $\begin{array}{c}4.9^{\mathrm{b}} \\
(1.15)\end{array}$ & $\begin{array}{c}1.0 \\
(0.55)\end{array}$ & $\begin{array}{c}0.5^{*} \\
(0.36)\end{array}$ & $\begin{array}{c}2.6 \\
(0.68)\end{array}$ & $\begin{array}{c}1.9 \\
(0.44)\end{array}$ & $\begin{array}{c}2.5 \\
(0.76)\end{array}$ & $\begin{array}{c}2.2 \\
(0.57)\end{array}$ & $\begin{array}{c}3.2 \\
(0.43)\end{array}$ & $\begin{array}{c}2.1 \\
(0.46)\end{array}$ \\
\hline \multicolumn{11}{|l|}{$\underline{\text { Density }}$} \\
\hline Amynthas & $\begin{array}{c}0.0 \\
(0.00)\end{array}$ & $\begin{array}{c}0.0 \\
(0.00)\end{array}$ & $\begin{array}{c}0.0 \\
(0.00)\end{array}$ & $\begin{array}{c}0.0 \\
(0.00)\end{array}$ & $\begin{array}{c}0.5^{\mathrm{a}} \\
(0.38)\end{array}$ & $\begin{array}{c}0.1^{\mathrm{b}} \\
(0.13)\end{array}$ & $\begin{array}{c}0.0 \\
(0.00)\end{array}$ & $\begin{array}{c}0.0 \\
(0.00)\end{array}$ & $\begin{array}{c}0.0 \\
(0.00)\end{array}$ & $\begin{array}{c}0.0 \\
(0.00)\end{array}$ \\
\hline L. rubellus & $\begin{array}{c}1.3 \\
(0.53)\end{array}$ & $\begin{array}{c}1.4 \\
(0.60)\end{array}$ & $\begin{array}{c}0.2 \\
(0.17)\end{array}$ & $\begin{array}{c}0.0 \\
(0.00)\end{array}$ & $\begin{array}{c}0.1 \\
(0.13)\end{array}$ & $\begin{array}{c}0.1 \\
(0.13)\end{array}$ & $\begin{array}{c}0.4 \\
(0.18)\end{array}$ & $\begin{array}{c}0.9 \\
(0.48)\end{array}$ & $\begin{array}{c}0.5^{\mathrm{a}} \\
(0.19)\end{array}$ & $\begin{array}{c}0.1^{\mathrm{b}} \\
(0.13)\end{array}$ \\
\hline Aporrectodea & $\begin{array}{c}17.9 \\
(3.10)\end{array}$ & $\begin{array}{l}10.9^{*} \\
(1.58)\end{array}$ & $\begin{array}{c}0.2 \\
(0.17)\end{array}$ & $\begin{array}{c}0.0 \\
(0.00)\end{array}$ & $\begin{array}{c}7.1^{\mathrm{a}} \\
(1.21)\end{array}$ & $\begin{array}{c}3.8^{\mathrm{b}} \\
(0.94)\end{array}$ & $\begin{array}{c}8.3 \\
(2.59)\end{array}$ & $\begin{array}{c}5.0 \\
(1.27)\end{array}$ & $\begin{array}{c}5.1 \\
(1.48)\end{array}$ & $\begin{array}{c}2.8 \\
(0.82)\end{array}$ \\
\hline Octolasion & $\begin{array}{c}2.9 \\
(0.58)\end{array}$ & $\begin{array}{c}2.0 \\
(0.50)\end{array}$ & $\begin{array}{c}0.0 \\
(0.00)\end{array}$ & $\begin{array}{c}0.0 \\
(0.00)\end{array}$ & $\begin{array}{c}1.6 \\
(0.53)\end{array}$ & $\begin{array}{c}1.0 \\
(0.33)\end{array}$ & $\begin{array}{c}1.8 \\
(0.59)\end{array}$ & $\begin{array}{c}1.1 \\
(0.44)\end{array}$ & $\begin{array}{c}0.6 \\
(0.18)\end{array}$ & $\begin{array}{c}0.6 \\
(0.18)\end{array}$ \\
\hline L. terrestris & $\begin{array}{c}6.5^{\mathrm{a}} \\
(0.71) \\
\end{array}$ & $\begin{array}{c}4.3^{\mathrm{b}} \\
(0.98) \\
\end{array}$ & $\begin{array}{c}1.2 \\
(0.47) \\
\end{array}$ & $\begin{array}{c}0.7 \\
(0.36)\end{array}$ & $\begin{array}{c}2.5 \\
(0.60)\end{array}$ & $\begin{array}{c}2.1 \\
(0.44)\end{array}$ & $\begin{array}{c}2.6 \\
(0.75)\end{array}$ & $\begin{array}{c}2.5 \\
(0.60)\end{array}$ & $\begin{array}{c}3.1^{\mathrm{a}} \\
(0.35) \\
\end{array}$ & $\begin{array}{c}2.0^{\mathrm{b}} \\
(0.50) \\
\end{array}$ \\
\hline
\end{tabular}


Table 2.7. Effects of L. maackii on total, adult, and juvenile worm biomass and density. Biomass is presented as g oven dried worm mass per $\mathrm{m}^{2}$. Density is given as the number of individuals per $\mathrm{m}^{2}$. Values are means ( $\mathrm{n}=8$ plots per treatment); parentheses enclose standard errors. Asterisks indicate a significant difference $(*: p \leq 0.05, * *: p \leq 0.01, * * *: p \leq 0.0001)$ between honeysuckle shrub present and removed plots for any single date, according to analyses of variance. Different letters indicates a strong trend $(0.05 \leq p \leq 0.10)$ between shrub present and shrub removed plots for any single date, according to analyses of variance.

\begin{tabular}{|c|c|c|c|c|c|c|c|c|c|c|}
\hline & \multicolumn{2}{|c|}{ Mar 2012} & \multicolumn{2}{|c|}{ June 2012} & \multicolumn{2}{|c|}{ Sept 2012} & \multicolumn{2}{|c|}{ Nov 2012} & \multicolumn{2}{|c|}{ Mar 2013} \\
\hline & $\begin{array}{l}\text { Shrubs } \\
\text { Present }\end{array}$ & $\begin{array}{c}\text { Shrubs } \\
\text { Removed }\end{array}$ & $\begin{array}{l}\text { Shrubs } \\
\text { Present }\end{array}$ & $\begin{array}{c}\text { Shrubs } \\
\text { Removed }\end{array}$ & $\begin{array}{l}\text { Shrubs } \\
\text { Present }\end{array}$ & $\begin{array}{c}\text { Shrubs } \\
\text { Removed }\end{array}$ & $\begin{array}{l}\text { Shrubs } \\
\text { Present }\end{array}$ & $\begin{array}{c}\text { Shrubs } \\
\text { Removed }\end{array}$ & $\begin{array}{l}\text { Shrubs } \\
\text { Present }\end{array}$ & $\begin{array}{c}\text { Shrubs } \\
\text { Removed }\end{array}$ \\
\hline $\begin{array}{c}\text { Total } \\
\text { biomass }\end{array}$ & $\begin{array}{r}19.5 \\
(2.02)\end{array}$ & $\begin{array}{l}12.3^{* *} \\
(1.46)\end{array}$ & $\begin{array}{c}2.9 \\
(1.11)\end{array}$ & $\begin{array}{c}1.6 \\
(0.73)\end{array}$ & $\begin{array}{c}7.1 \\
(2.08)\end{array}$ & $\begin{array}{c}4.6 \\
(1.06)\end{array}$ & $\begin{array}{c}7.4 \\
(1.65)\end{array}$ & $\begin{array}{c}5.4 \\
(1.28)\end{array}$ & $\begin{array}{c}6.2^{\mathrm{a}} \\
(1.00)\end{array}$ & $\begin{array}{c}4.3^{b} \\
(0.66)\end{array}$ \\
\hline $\begin{array}{c}\text { Total } \\
\text { density }\end{array}$ & $\begin{array}{r}92.6 \\
(7.04)\end{array}$ & $\begin{array}{l}59.8^{* * *} \\
(4.14)\end{array}$ & $\begin{array}{c}13.0 \\
(3.76)\end{array}$ & $\begin{array}{c}7.8 \\
(2.79)\end{array}$ & $\begin{array}{l}34.3^{\mathrm{a}} \\
(7.46)\end{array}$ & $\begin{array}{l}23.0^{\mathrm{b}} \\
(5.22)\end{array}$ & $\begin{array}{l}37.3^{\mathrm{a}} \\
(7.17)\end{array}$ & $\begin{array}{l}26.1^{b} \\
(4.83)\end{array}$ & $\begin{array}{c}58.8 \\
(7.68)\end{array}$ & $\begin{array}{c}51.6 \\
(7.13)\end{array}$ \\
\hline $\begin{array}{c}\text { Adult } \\
\text { biomass }\end{array}$ & $\begin{array}{c}9.5 \\
(1.49)\end{array}$ & $\begin{array}{c}6.1^{*} \\
(1.23)\end{array}$ & $\begin{array}{c}1.1 \\
(0.55)\end{array}$ & $\begin{array}{c}0.5 \\
(0.36)\end{array}$ & $\begin{array}{c}3.2 \\
(0.72)\end{array}$ & $\begin{array}{c}2.2 \\
(0.51)\end{array}$ & $\begin{array}{c}3.3 \\
(0.97)\end{array}$ & $\begin{array}{c}2.7 \\
(0.59)\end{array}$ & $\begin{array}{c}3.6 \\
(0.41)\end{array}$ & $\begin{array}{c}2.4 \\
(0.47)\end{array}$ \\
\hline $\begin{array}{c}\text { Adult } \\
\text { density }\end{array}$ & $\begin{array}{c}28.5 \\
(4.15)\end{array}$ & $\begin{array}{l}18.5^{*} \\
(1.78)\end{array}$ & $\begin{array}{c}1.5 \\
(0.47)\end{array}$ & $\begin{array}{c}0.7 \\
(0.36)\end{array}$ & $\begin{array}{c}11.9 \\
(1.93)\end{array}$ & $\begin{array}{c}7.1^{*} \\
(1.95)\end{array}$ & $\begin{array}{c}13.0 \\
(3.44)\end{array}$ & $\begin{array}{c}9.5 \\
(1.64)\end{array}$ & $\begin{array}{c}9.4^{\mathrm{a}} \\
(1.85)\end{array}$ & $\begin{array}{c}5.5^{\mathrm{b}} \\
(1.27)\end{array}$ \\
\hline $\begin{array}{l}\text { Juvenile } \\
\text { biomass }\end{array}$ & $\begin{array}{c}10.0 \\
(1.05)\end{array}$ & $\begin{array}{c}6.2^{*} \\
(0.67)\end{array}$ & $\begin{array}{c}1.9 \\
(0.68)\end{array}$ & $\begin{array}{c}1.1 \\
(0.43)\end{array}$ & $\begin{array}{c}3.9 \\
(1.43)\end{array}$ & $\begin{array}{c}2.3^{*} \\
(0.65)\end{array}$ & $\begin{array}{c}4.1 \\
(0.83)\end{array}$ & $\begin{array}{c}2.7^{*} \\
(0.73)\end{array}$ & $\begin{array}{c}2.6 \\
(0.72)\end{array}$ & $\begin{array}{c}1.9 \\
(0.33)\end{array}$ \\
\hline $\begin{array}{c}\text { Juvenile } \\
\text { density }\end{array}$ & $\begin{array}{r}64.1 \\
(6.07)\end{array}$ & $\begin{array}{l}41.3^{* * *} \\
(3.91)\end{array}$ & $\begin{array}{c}11.5 \\
(3.47)\end{array}$ & $\begin{array}{c}7.2 \\
(2.62)\end{array}$ & $\begin{array}{c}22.4 \\
(6.36)\end{array}$ & $\begin{array}{c}15.9 \\
(4.06)\end{array}$ & $\begin{array}{c}24.3 \\
(4.87)\end{array}$ & $\begin{array}{c}16.6 \\
(4.02)\end{array}$ & $\begin{array}{c}49.4 \\
(6.73)\end{array}$ & $\begin{array}{c}46.1 \\
(6.48)\end{array}$ \\
\hline
\end{tabular}


Table 2.8. The strongest overall multiple regression model for total earthworm biomass at each date (see Appendix 2 for all models). Only shrub present plots were used in this analysis. Blank cells indicate variables that were dropped from the model.

\begin{tabular}{|c|c|c|c|c|c|c|c|c|c|c|c|c|}
\hline & \multirow[b]{2}{*}{$\mathrm{F}$} & \multirow[b]{2}{*}{$\mathrm{p}$-value } & \multirow[b]{2}{*}{ Adj $r^{2}$} & \multirow[b]{2}{*}{ Intcp. } & \multicolumn{2}{|c|}{ Stem density } & \multicolumn{2}{|c|}{ Soil temp } & \multicolumn{2}{|c|}{ Soil moist } & \multicolumn{2}{|c|}{ Bedrock depth } \\
\hline & & & & & Coeff. & $\mathrm{p}$-value & Coeff. & $\mathrm{p}$-value & Coeff. & $\mathrm{p}$-value & Coeff. & $\mathrm{p}$-value \\
\hline Mar 2012 & 3.58 & 0.11 & 0.42 & 26.94 & 0.00041 & 0.35 & & & & & -0.134 & 0.066 \\
\hline June 2012 & 2.55 & 0.17 & 0.31 & 72.90 & 0.000020 & 0.94 & -3.195 & 0.074 & & & & \\
\hline Sept 2012 & 7.30 & 0.042 & 0.73 & 162.62 & 0.00066 & 0.089 & -7.193 & 0.014 & 23.248 & 0.080 & & \\
\hline Nov 2012 & 0.78 & 0.41 & 0.12 & 2.97 & 0.00038 & 0.41 & & & & & & \\
\hline Mar 2013 & 20.59 & 0.0068 & 0.89 & -9.24 & 0.00070 & 0.0026 & -1.760 & 0.022 & 41.380 & 0.0021 & & \\
\hline
\end{tabular}


Table 2.9. Differences in decomposition of honeysuckle and sugar maple leaf litter in bags of two mesh sizes. Values are mean $\%$ mass lost; parentheses enclose standard errors $(\mathrm{n}=8)$. Asterisks indicate a significant difference $(*: p \leq 0.05, * *: p \leq 0.01$, $* * *: p \leq 0.0001)$ between large mesh $(10 \mathrm{~mm})$ and small mesh $(1 \mathrm{~mm})$ bags for either shrub present or shrub removed plots within any single date, according to analyses of variance. No significant differences were observed between shrub present and shrub removal plots at any single date.

\begin{tabular}{|c|c|c|c|c|c|c|c|c|c|c|}
\hline & \multicolumn{2}{|c|}{$2 / 17 / 12$ to $4 / 3 / 12$} & \multicolumn{2}{|c|}{$5 / 16 / 12$ to $7 / 1 / 12$} & \multicolumn{2}{|c|}{$8 / 6 / 12$ to $9 / 21 / 12$} & \multicolumn{2}{|c|}{$10 / 9 / 12$ to $11 / 24 / 12$} & \multicolumn{2}{|c|}{$2 / 17 / 13$ to $4 / 3 / 13$} \\
\hline & $\begin{array}{l}\text { Large } \\
\text { Mesh }\end{array}$ & $\begin{array}{l}\text { Small } \\
\text { mesh }\end{array}$ & $\begin{array}{l}\text { Large } \\
\text { Mesh }\end{array}$ & $\begin{array}{c}\text { Small } \\
\text { mesh }\end{array}$ & $\begin{array}{l}\text { Large } \\
\text { Mesh }\end{array}$ & $\begin{array}{l}\text { Small } \\
\text { mesh }\end{array}$ & $\begin{array}{l}\text { Large } \\
\text { Mesh }\end{array}$ & $\begin{array}{l}\text { Small } \\
\text { mesh }\end{array}$ & $\begin{array}{l}\text { Large } \\
\text { Mesh }\end{array}$ & $\begin{array}{c}\text { Small } \\
\text { mesh }\end{array}$ \\
\hline \multicolumn{11}{|l|}{ Honeysuckle litter } \\
\hline Shrubs present & $\begin{array}{l}100.00 \\
(0.000)\end{array}$ & $\begin{array}{l}46.84^{* *} \\
(8.241)\end{array}$ & $\begin{array}{c}87.17 \\
(3.147)\end{array}$ & $\begin{array}{l}32.90^{* * *} \\
(4.588)\end{array}$ & $\begin{array}{c}77.04 \\
(6.638)\end{array}$ & $\begin{array}{l}37.38^{* *} \\
(5.714)\end{array}$ & $\begin{array}{c}66.09 \\
(4.896)\end{array}$ & $\begin{array}{c}24.40^{* * *} \\
(2.208)\end{array}$ & $\begin{array}{c}65.80 \\
(5.213)\end{array}$ & $\begin{array}{c}22.55^{* * *} \\
(2.039)\end{array}$ \\
\hline Shrubs removed & $\begin{array}{l}100.00 \\
(0.000)\end{array}$ & $\begin{array}{l}48.96^{* *} \\
(7.387)\end{array}$ & $\begin{array}{c}80.16 \\
(5.002)\end{array}$ & $\begin{array}{l}30.95^{* *} \\
(2.989)\end{array}$ & $\begin{array}{c}75.27 \\
(7.737)\end{array}$ & $\begin{array}{l}41.65^{*} \\
(5.883)\end{array}$ & $\begin{array}{c}59.97 \\
(2.457)\end{array}$ & $\begin{array}{l}28.89^{* *} \\
(0.842)\end{array}$ & $\begin{array}{c}66.25 \\
(5.444)\end{array}$ & $\begin{array}{c}24.17^{* * *} \\
(0.827)\end{array}$ \\
\hline \multicolumn{11}{|l|}{$\underline{\text { Sugar maple litter }}$} \\
\hline Shrubs present & $\begin{array}{c}18.72 \\
(5.074)\end{array}$ & $\begin{array}{l}3.15^{* * *} \\
(0.609)\end{array}$ & $\begin{array}{c}8.12 \\
(2.085)\end{array}$ & $\begin{array}{l}2.25^{* * *} \\
(0.317)\end{array}$ & $\begin{array}{c}7.92 \\
(2.480)\end{array}$ & $\begin{array}{l}2.01^{* * *} \\
(0.430)\end{array}$ & $\begin{array}{c}10.23 \\
(1.653)\end{array}$ & $\begin{array}{l}5.63^{* *} \\
(1.227)\end{array}$ & $\begin{array}{c}11.95 \\
(0.870)\end{array}$ & $\begin{array}{l}4.63^{* * *} \\
(1.052)\end{array}$ \\
\hline Shrubs removed & $\begin{array}{c}15.60 \\
(2.714)\end{array}$ & $\begin{array}{l}3.75^{* * *} \\
(0.491)\end{array}$ & $\begin{array}{c}6.60 \\
(1.414) \\
\end{array}$ & $\begin{array}{l}3.18^{* *} \\
(0.541) \\
\end{array}$ & $\begin{array}{c}10.34 \\
(2.727) \\
\end{array}$ & $\begin{array}{l}2.97^{* * *} \\
(0.980)\end{array}$ & $\begin{array}{c}11.49 \\
(1.480)\end{array}$ & $\begin{array}{l}6.00^{* *} \\
(1.078) \\
\end{array}$ & $\begin{array}{c}8.15 \\
(0.814) \\
\end{array}$ & $\begin{array}{l}5.79^{\text {n.s. }} \\
(0.686) \\
\end{array}$ \\
\hline
\end{tabular}




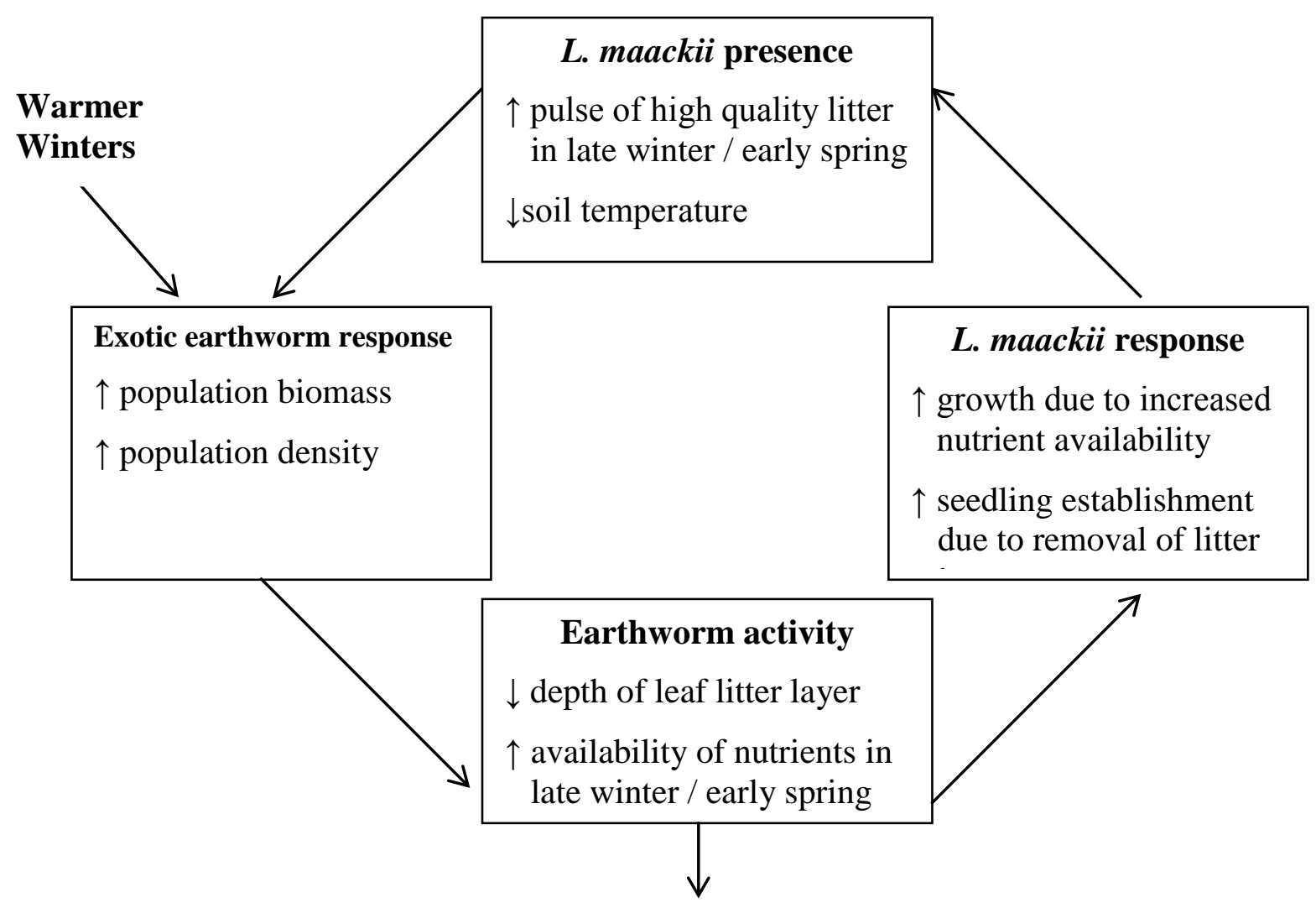

Potential N loss from system

Figure 2.1. Potential interactions between exotic earthworm species and the invasive shrub Lonicera maackii. L. maackii provides large quantities of high quality litter (i.e. low $\mathrm{C}: \mathrm{N}$, low phenolic content) during the later fall to early winter and alters soil microclimate (i.e. cooler soil temperatures) during the summer. Litter inputs serve as a early spring food source and honeysuckle presence promotes and increase in the population size of invasive earthworms. Feeding by earthworm during the late winter to early spring provides an early season nutrient pulse that only invasive species with an extended leaf phenology (e.g. L. maackii) can exploit and utilize for growth. If L. maackii shrubs are unable to utilize these nitrogen pools, there may increase export of $\mathrm{N}$ from terrestrial systems to aquatic systems. Earthworm may also promote honeysuckle invasion by reducing the leaf litter layer and creating bare soil conditions for L. maackii seedling establishment. This creates a positive feedback loop in which L. maackii and invasive earthworms promote each other's invasion and may increase the impacts of invasion (e.g. increased $\mathrm{N}$ loss). These interactions may also be modulated by climate change with warmer winters allow worms to stay active throughout the winter. 


\section{Biomass}
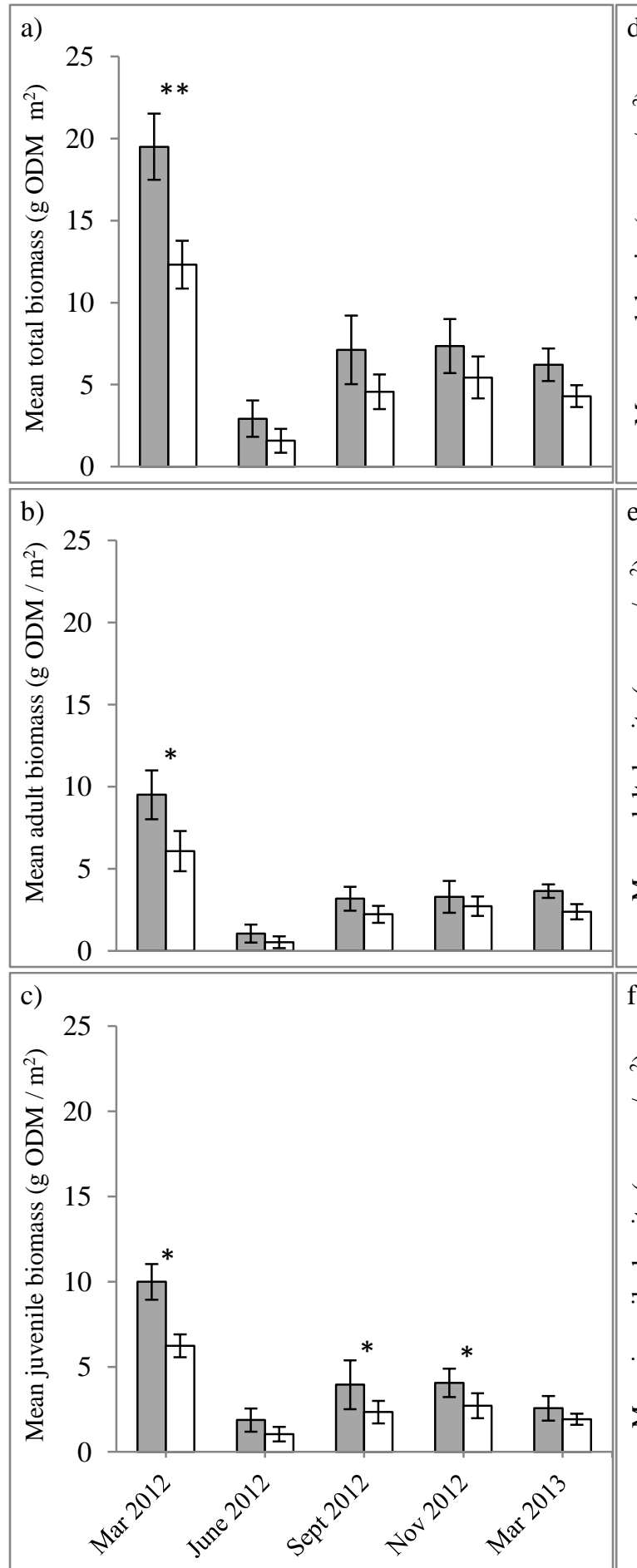

Density
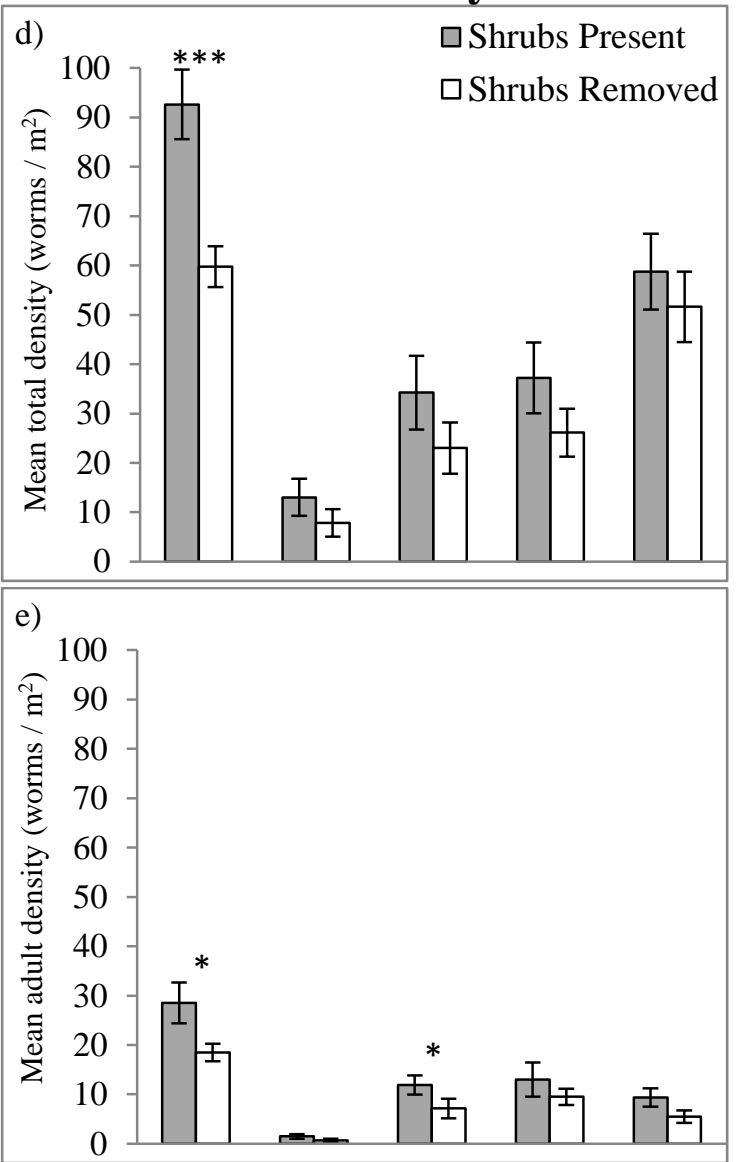

f)

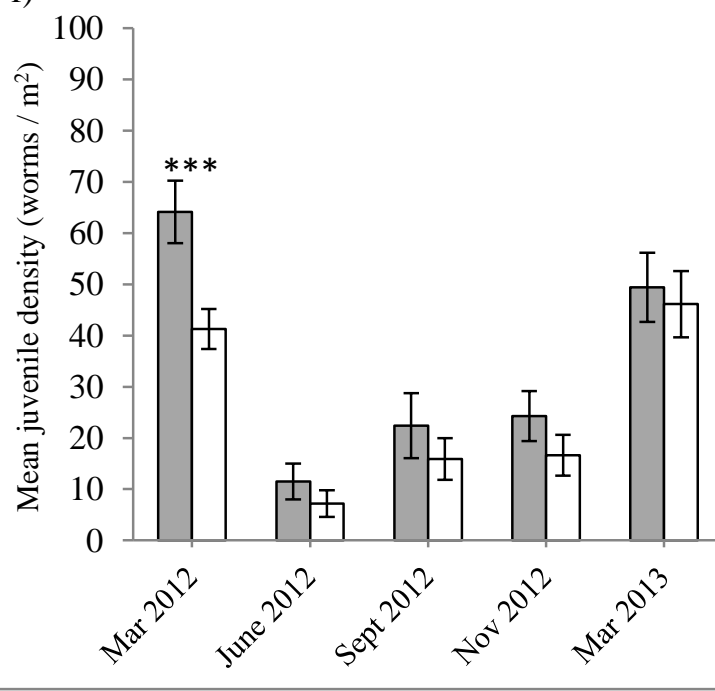

Figure 2.2. Mean total worm biomass (a), mean adult worm biomass (b), mean juvenile worm biomass (c), mean total worm density (d), mean adult worm density (e), and mean juvenile worm density (f). Bars represent the mean $( \pm \mathrm{SE})$. Asterisks denote statistical significance between shrub present and removed sites for any single date $\left(^{*}: \mathrm{p}<0.05\right.$, $* *: \mathrm{p}<0.01, * * *: \mathrm{p}<0.0001, \mathrm{n}=8)$. 


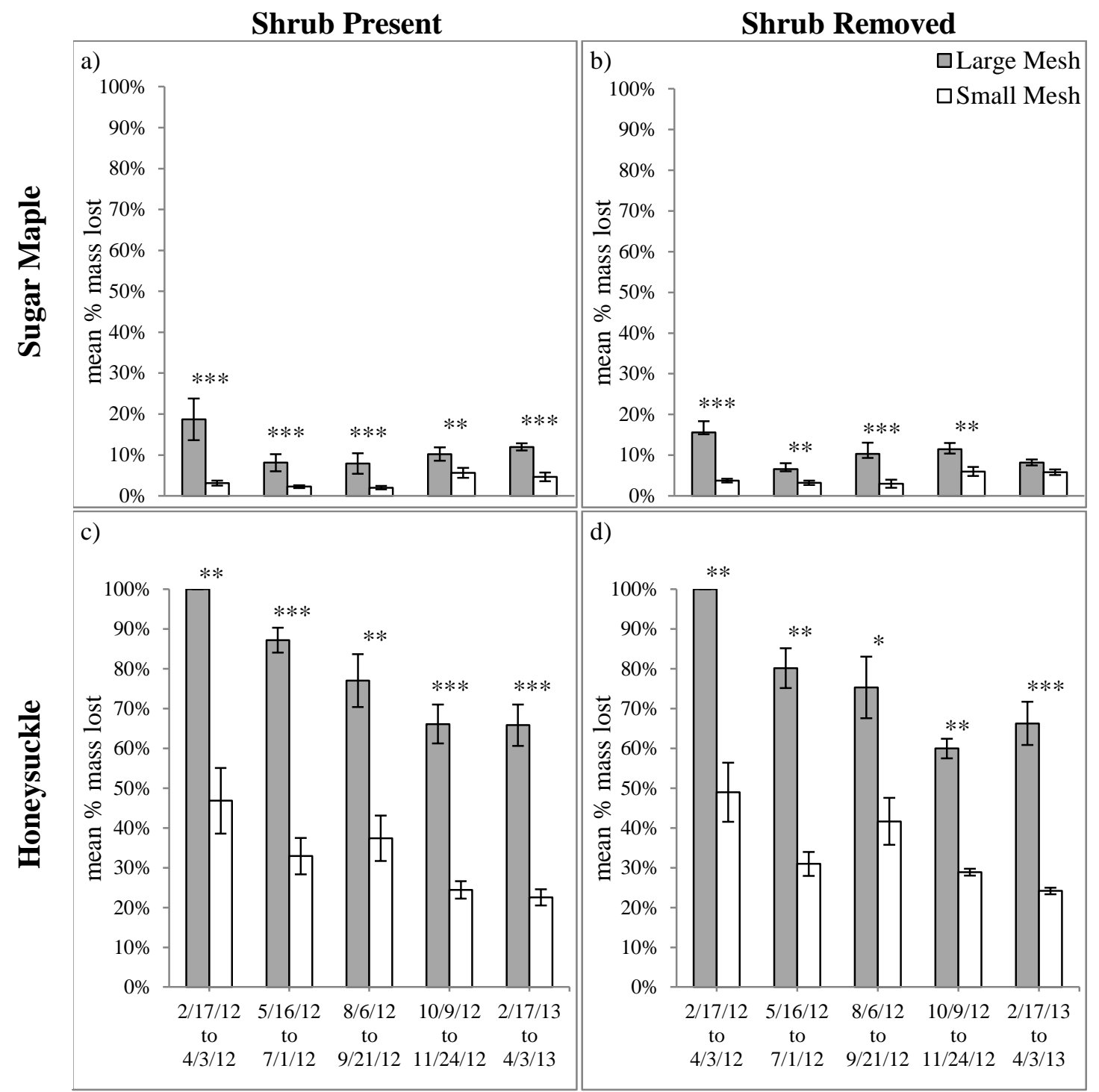

Figure 2.3. Effect of mesh size on litter mass loss at different seasons of the year. Mean percent $( \pm$ SE) mass lost in honeysuckle shrub present and shrub removed plots, respectively, for maple litter $(\mathrm{a}, \mathrm{b})$ and honeysuckle litter $(\mathrm{c}, \mathrm{d})$. Asterisks denote statistical significance between mesh sizes for any single date $\left({ }^{*} \mathrm{p} \leq 0.05,{ }^{* *} \mathrm{p} \leq 0.01,{ }^{* * *} \mathrm{p} \leq 0.0001\right)$. No statistical significance difference were observed between honeysuckle shrub present and removed plots at any date. 

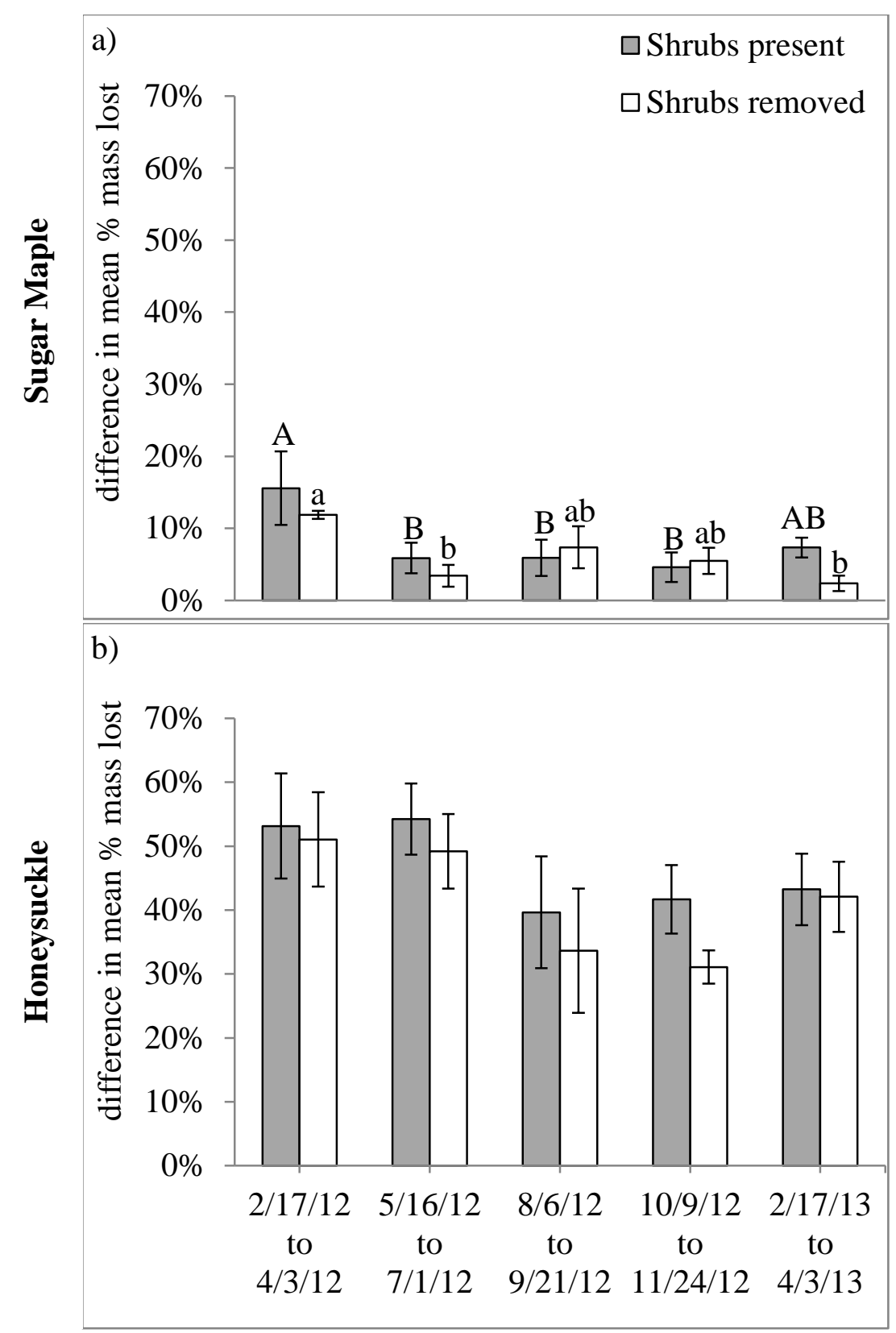

Figure 2.4. Index of soil macroinvertebrate activity at different seasons of the year using difference in mean percent mass lost between mesh sizes. Differences for maple litter (a) and honeysuckle litter (b) were calculated by subtracting the percent mass loss in small mesh bags from the percent mass loss in large mesh bags $( \pm$ SE). Taller bars indicate greater mass loss in large mesh bags relative to small mesh bags and therefore higher levels of soil macroinvertebrate detritivore activity. Uppercase and lowercase letters indicate significant differences $(p \leq 0.05)$ between dates within shrub present and shrub removal plots, respectively. No statistically significant differences were observed between honeysuckle shrub present and removed plots within any particular date using the false discovery rate for multiple comparisons. 


\section{CHAPTER III}

\section{LEAF LITTER DECOMPOSITION AND NITROGEN RELEASE PATTERNS IN AN URBAN WOODLAND INVADED BY EXOTIC HONEYSUCKLE SHRUBS: THE EFFECTS OF LITTER MIXING AND SOIL MACROINVERTEBRATES}

\section{$\underline{\text { Introduction }}$}

Because annual nutrient inputs to terrestrial ecosystems are often low (Schlesinger and Bernhardt 2013), decomposition of leaf litter represents the primary pathway by which nutrients are returned to the soil and made available for plant uptake. Decomposition is a complex process that is influenced by a number of interacting factors, including regional climate (Meentemeyer 1978; Couteaux et al. 1995; Aerts 1997), microclimatic conditions (Moore 1986; Hornsby et al. 1995), the chemical quality of the leaf litter (Pereira et al. 1998; Melillo et al. 1982), and the decomposer community (Witkamp 1966; Seastedt 1984; Heneghan et al. 2007). Much of our understanding of decomposition and the factors that influence it comes from studies focusing on the litter dynamics of single species (Blair et al. 1990). In nature, however, leaf litter is often found in multi-species mixtures (Salamanca et al. 1998) and studies have reported both synergistic and antagonistic effects of mixtures on decay rates (Gartner and Cardon 2004). Some studies have attributed the synergistic effect of litter mixing to differences in 
initial nitrogen concentration between litters (Wardle et al. 1997, Hector et al. 2000), though others have questioned its usefulness in explaining litter interactions (Hoorens et al. 2003; Smith and Bradford 2003).

The effects of mixing different quality litters and the roles soil macroinvertebrate detritivores play in regulating rates of decay and nutrient release may be of particular interest in urban forests. These forests tend to have reduced native plant species richness and feature higher numbers of non-native woody species than their more rural counterparts (McKinney 2002; Zipperer and Guntenspergen 2009; Trammell and Carreiro 2011). These non-native woody species often produce leaf litter that is higher in quality (higher $\mathrm{N}$ concentration, lower $\mathrm{C}: \mathrm{N}$ ratio, lower lignin: $\mathrm{N}$ ratio) and which decomposes faster than the litter of co-occurring woody natives (Ehrenfeld 2003; Ashton et al. 2005; Liao et al. 2008). Nutrient translocation and other interactions between invasive and native litters may result in accelerated decomposition of native litters and a faster cycling of $\mathrm{N}$ in soils (Liao et al. 2008). This may allow invasive species with an extended leaf phenology to promote their own growth by creating an early spring nutrient pulse that they can exploit but few other species can (Eppinga et al. 2011; Trammell and Carreiro 2012). Interactions between decaying invasive and native litters may be modulated by soil macroinvertebrate detritivores (Schädler and Brandl 2005), particularly exotic, litter-feeding species of earthworms (Bohlen et al. 2004c; Holdsworth et al. 2012). Because these species preferentially feed on litters with low C:N ratios and low polyphenol concentrations (Hendriksen 1990), litter-feeding earthworms may selectively remove invasive litter before it can influence the decomposition and nutrient release dynamics of native litter. Therefore, it is important to consider both the effects of litter 
mixtures and how these effects are regulated by the activity of not only microbes, but also soil macroinvertebrate detritivores in order to understand leaf litter decomposition and nutrient cycling in forests invaded by exotic plants. In this study, I examine the effects of the invasive shrub Lonicera maackii (Amur honeysuckle) and soil macroinvertebrate detritivores (predominantly invasive Eurasian earthworms) on the decomposition of exotic L. maackii and native Acer saccharum (sugar maple) leaf litter from late winter to early spring.

Amur honeysuckle (hereafter referred to as 'honeysuckle') was introduced to North America from Asia in 1896 as an ornamental shrub (Luken and Thieret 1996). Naturalized populations were documented as early as the 1950s (Luken and Thieret 1996) and since then, it has established populations in Ontario, Canada and 28 states in the United States (USDA NRCS 2014). Canopy disturbance and gap formation allow for initial establishment (Luken and Goessling 1995; Hutchinson and Vankat 1997) and shrub populations are able to persist and spread due to an extended leaf phenology (Trisel and Gorchov 1994; McEwan et al. 2009a) and high allocation towards reproduction (Ingold and Craycraft 1983). As invasion proceeds, relatively open forest understories are replaced by dense monocultures of honeysuckle shrubs (Collier et al. 2002). These shrub thickets can alter the vertical structure of forests (Hartman and McCarthy 2008) and negatively affect the establishment and growth of herbaceous and woody natives (Collier et al. 2002; Gorchev and Trisel 2003; Miller and Gorchov 2004). Shrub honeysuckle may alter decomposition and nutrient dynamics in invaded forests by producing large inputs of high quality litter (lower C:N, lower percent lignin, lower lignin:N ratio, and lower LCI compared to co-occuring natives) or by altering soil temperature and moisture patterns 
via shading (Poulette and Arthur 2012; Trammell et al. 2012). Over time, occupation by shrub honeysuckle may alter soil nutrient cycling as well as microbial and macroinvertebrate communities (Arthur et al. 2012; McEwan et al. 2012; Chapter 2).

Trammell et al. (2012) suggested that decomposition of honeysuckle litter may create a positive feedback loop that promotes the growth of honeysuckle shrubs. Decomposition rates for honeysuckle litter have been reported to be three to four times higher than sugar maple (A. saccharum) litter (Blair and Stowasser 2009; Trammell et al. 2012), five times higher than white ash (Fraxinus americana) and hickory (Carya spp) litter (Arthur et al. 2012), and 21 times higher than northern red oak (Quercus rubra) litter (Blair and Stowasser 2009). Poulette and Arthur (2012) reported that litter from $L$. maackii shrubs decomposed and lost $\mathrm{N}$ more rapidly than litter from blue ash (Fraxinus quadrangulata), chinkapin oak (Quercus muehlenbergii), or shagbark hickory (Carya ovata). Therefore, rapid decomposition of honeysuckle litter may create large, labile pools of nitrogen during the late winter to early spring period. While most woody native plants are still dormant during this time period, invasive shrub honeysuckles in the Louisville area tend to leaf out during the late winter to early spring (mid-February to early March). Photosynthesis during the early spring has been reported to account for $25 \%$ to $35 \%$ of annual carbon gain in other invasive Lonicera taxa (Lonicera x bella; Harrington et al. 1989), suggesting that Lonicera maackii may be able to utilize these early spring nitrogen pools. Documenting a large pulse of $\mathrm{N}$ during the late winter to early spring would provide evidence of a potential feedback loop that permits honeysuckle to retain and intensify its dominant position in the forest understory. However, the timing of this $\mathrm{N}$ pulse could be affected by other factors such as mixing 
with canopy tree litters, an active macronivertebrate community, and/or soil legacies of the shrub's prolonged presence. Therefore, the specific objectives for this study were to determine: (1) if mass remaining and the timing and amount of $\mathrm{N}$ released from honeysuckle and sugar maple litter is affected by mixing, (2) if these litter dynamics differ where this shrub is or is not present in the woodlands, (3) the extent to which macroinvertebrates affect mass remaining and $\mathrm{N}$ release of these single and mixed litters from late winter to early spring.

To differentiate between the effects of litter and the effects of potential alterations of soil resources, conditions, and biota by this shrub, I conducted a litterbag experiment using three litter types (honeysuckle, sugar maple, and a mixture of the two) in forest plots where the shrub was present and plots where it had been removed four years previously. Comparing litter decomposition and $\mathrm{N}$ release within plots of the same treatment category (shrubs present or shrubs removed) allowed me to determine the effect of mixing honeysuckle and sugar maple litter on these processes. I predicted that due to its higher $\mathrm{N}$ and lower lignin content, honeysuckle litter would decompose faster than sugar maple litter and that mixing these litters would enhance decomposition and $\mathrm{N}$ release in a non-additive manner. Comparing litter decomposition and $\mathrm{N}$ release between plot treatment categories (shrubs present vs. shrubs removed) allowed me to examine the effects of shrub presence or absence on these processes. I did not posit directionality as to whether shrub presence might accelerate or reduce litter decay, because of the potential existence of current and soil legacy effects with opposing influences on these processes.

The effects of soil macroinvertebrate detritivores were assessed using litterbags of two different mesh sizes. Because macroinvertebrates were able to remove litter from 
large-mesh bags but not small-mesh bags, I predicted that mass remaining and nitrogen dynamics would differ between the two bag sizes. Soil macroinvertebrates are known to preferentially feed on high quality honeysuckle litter over native sugar maple litter (Chapter 1). Therefore, I expected the effects of litter mixing on mass remaining and net $\mathrm{N}$ loss or retention to differ depending on whether macroinvertebrates had access to or were excluded from leaf litter inside the bags.

\section{Methods}

\section{Study area}

This study was conducted in Cherokee Park, a 166-ha Olmsted park located in Louisville, KY, USA ( $\left.38^{\circ} 14^{\prime} 28.32^{\prime \prime} \mathrm{N}, 85^{\circ} 41^{\prime} 48.84^{\prime \prime} \mathrm{W}\right)$. The mean annual temperature in Louisville is $13.8^{\circ} \mathrm{C}$ and the region is characterized by warm, humid summers (mean July temperatures of $25.8^{\circ} \mathrm{C}$ ) and cool winters (mean January temperatures of $0.5^{\circ} \mathrm{C}$ ) (NCDC 2012). Mean annual precipitation is $113 \mathrm{~cm}$ and is evenly distributed throughout the year (Klebler 2000). The park is a mixture of fragmented woodlands and open mowed fields and has a long history of natural and anthropogenic disturbance (Carreiro and Zipperer 2011). In 1974, an F4 tornado destroyed most mature canopy trees, permitting honeysuckle and other invasive shrubs and vines to establish and become dominant over the ensuing decades (Carreiro and Zipperer 2011). The ongoing loss of ash (Fraxinus spp) trees due to the spread of emerald ash borer (Agrilus planipennis) may create further canopy disturbance (Poland and McCullough 2006), allowing honeysuckle to persist and expand its population throughout Louisville's urban woodlands. 
Eight study sites were established within the park in March of 2008 (Chapter 1). Each site featured two $10 \times 10$ meter plots separated by a minimum five-meter buffer zone. In January of 2009, all honeysuckle shrubs were cut and removed in one randomly selected plot at each site. Any shrubs present in the surrounding buffer zone were not removed. Freshly cut stumps were painted with $26 \%$ glyphosate isopropylamine salt solution (Roundup; Monsanto Company, St. Louis, MO, USA) to ensure shrub death. No additional shrub removals or herbicide treatments were applied after 2009. From these eight original sites, a subset of five sites was chosen for this experiment (Table 3.1). Only sites with relatively high honeysuckle stem densities $\left(12,800-17,700\right.$ living stems ha $\left.^{-1}\right)$ and honeysuckle basal areas $\left(2.93-8.38 \mathrm{~m}^{2} \mathrm{ha}^{-1}\right)$ were included in the subset. This ensured a high contrast between honeysuckle present and removed plots and avoided including sites with high densities of other exotic shrubs.

Ash (Fraxinus spp.) was the most common dominant or co-dominant species in the tree canopy at these five sites with sugar maple (Acer saccharum Marsh.) being the most abundant species throughout the park. Common hackberry (Celtis occidentalis L.) and tulip poplar (Liriodendron tulipifera L.) were common secondary species (unpublished Olmsted Park Conservancy Inventories 2007 and 2013). All dominant canopy trees at our five sites were native species. Soils at these sites varied from welldrained, moderately deep Hapludalfs in the Caneyville series to very deep Paleudalfs in the Crider series. Slopes ranged from moderately steep (10-30 percent slope) to steep (3060 percent slope). In the upper $10 \mathrm{~cm}$ soil horizon, $\mathrm{pH}$ ranged from 5.33 to 7.8 among plots, organic matter content (carbonate-free) ranged from $4.25 \%$ to $10.6 \%$, and the C:N molar ratio ranged between 10.6 and 15.2 (Carreiro, unpublished). 


\section{Litterbag experiment}

Senescent sugar maple and honeysuckle leaves were collected in October 2011 and December 2011, respectively, using large plastic ground tarps. Two collection periods were necessary due to the different timing of leaf senescence between sugar maple (October) and honeysuckle (December-January). Sugar maple was selected as a native comparison litter for two reasons. First, sugar maple is the most abundant canopy species throughout Cherokee Park woodlands and its litter is a major component of annual litter fall. Second, populations of native shrubs in the park are extremely low, making it less meaningful to use a comparable native shrub species (e.g. Lindera benzoin) for this study. Collections were made every three days for three weeks and any captured leaves were transported to a heated warehouse and allowed to air dry on large plastic tarps for a period of two months. Leaves were turned weekly for the first three weeks to allow for proper drying. Prior to being placed in litterbags, leaves were sorted by species and collections from different collection dates were pooled and mixed.

Most studies examining the decomposition dynamics of honeysuckle litter have only used 1x1 mm mesh sizes (Blair and Stowasser 2009; Poulette and Arthur 2012; Trammell et al. 2012). However, soil macroinvertebrate detritivores play an important role in leaf litter decomposition and nutrient cycling (Irmler 2000; Bradford et al. 2002; Schädler and Brandl 2005) and using litterbags of varying mesh sizes is a common method for quantifying their importance (Bradford et al. 2002). For this study, litterbags of two different mesh sizes were used. Small-mesh bags were constructed using fiberglass window screening (Gray Fiberglass Screen Wire, New York Wire, Grand Island, NY, USA) with a 1x1 mm mesh size, while large-mesh bags were constructed 
using polypropylene pond netting (Pond and Pool netting, Dalen, Knoxville, TN, USA) with a 10x10 mm mesh size. Small-mesh bags allowed soil microbes and mesofauna to access litter but restricted macroinvertebrates (e.g. earthworms, millipedes). Large-mesh bags permitted macroinvertebrate access to leaf litter in addition to soil microbes and mesofauna. Litterbags were constructed with an inside pocket area of $25 \times 35 \mathrm{~cm}$ because this size allowed sufficient spread of litter inside the bags and was small enough to easily transport and place in the field. Litterbags of each mesh size were filled with five grams (range: 5.00 - $5.05 \mathrm{~g}$ ) of either honeysuckle litter, sugar maple litter, or a mixture of honeysuckle and sugar maple litter. The mixed litter was composed of approximately $85 \%$ sugar maple litter by mass (range: $4.22-4.28 \mathrm{~g}$ ) and 15\% honeysuckle litter (range: $0.72-0.78 \mathrm{~g}$ ). These percentages were based on litter fall data collected in 2010 and are representative of the average tree-to-honeysuckle litter ratio present at these sites. In addition, the mixed bags were filled so that honeysuckle litter was placed on top of maple litter to replicate honeysuckle's later senescence date. Bags were grouped into blocks with each block featuring all six possible mesh size and litter combinations. A total of three blocks (18 bags) were placed in each plot during the sampling period and each block was arranged in a grid pattern (bag order and position within the grid were randomized). All blocks were positioned at least 0.5 meter away from the plot edge to avoid any potential effects from overhanging honeysuckle shrubs in the buffer zone of the removal plots.

Litterbags were placed in the field on February 17, 2013 and all bags were secured directly to the mineral soil surface using landscaping staples. On the day bags were deployed, three additional blocks (18 bags) were also taken into the field but 
collected immediately. These "drop bags" were returned to the lab and oven dried at $60^{\circ} \mathrm{C}$ for 48 hours to calculate correction factors for air-dry to oven dry mass conversion and any mass lost due to handling. Unlike most decomposition experiments, this experiment featured only one collection date, with all bags being collected from the field on April 3, 2013 (46 days of incubation). This was done because I expected honeysuckle litter in large-mesh bags to decompose rapidly during the late winter to early spring based on the results from a past study (Chapter 1). Therefore, planning a study of longer duration would not have been ecologically meaningful. In addition, I was specifically interested in the mass remaining and net $\mathrm{N}$ uptake or release dynamics during the window of time when honeysuckle had broken bud but other woody natives were still dormant. Honeysuckle leaf expansion typically occurs in late February to early March in the Louisville area, while leaf expansion for most woody native doesn't occur until early April. By selecting an incubation period that matches the invasive and native leaf expansion window, I was able to examine the potential for a positive feedback loop occurring between litter decomposition and $\mathrm{N}$ loss and invasive shrub honeysuckles.

Litter bags were placed into individual paper bags during transport to the lab to prevent litter loss due to handling. Because differences in mesh size could allow leaf fragments to be lost at a disproportionately higher rate from large mesh bags, any fragments identifiable as honeysuckle or maple litter located directly beneath the bags were also collected along with the corresponding litterbag. Leaves were brushed clean of soil and live plant material and oven dried at $60^{\circ} \mathrm{C}$ for 48 hours. Air-dry to oven dry mass correction factors were applied to air-dry starting weights. The oven-dry mass remaining in each bag was then divided by the corrected oven-dry starting weight for the same bag 
to determine the $\%$ mass remaining. The dried litter from each bag was ground in a Wiley Mill and passed through a \#20 mesh. Subsamples of the ground litter were analyzed for carbon (C) and nitrogen (N) content using a Perkin-Elmer 2400 Series II CHNS/O analyzer (Shelton, CT, USA). To measure the $\mathrm{N}$ content present in each bag, litter $\mathrm{N}$ concentration ( $\mathrm{g} \mathrm{N} \mathrm{g}^{-1}$ litter) was multiplied by the oven dry litter mass remaining. Percent of initial $\mathrm{N}$ mass remaining was then calculated by dividing the final $\mathrm{N}$ content in each litter bag by the initial $\mathrm{N}$ content and multiplying by $100 \%$ (Eq. 1).

$$
\% \mathrm{~N}_{\text {remaining }}=\left[\frac{\left(\mathrm{N}_{\mathrm{t}} * \mathrm{M}_{\mathrm{t}}\right)}{\mathrm{N}_{0}}\right] * 100 \%
$$

where $\mathrm{N}_{\mathrm{t}}=\mathrm{N}$ concentration at time $\mathrm{t}, \mathrm{M}_{\mathrm{t}}=$ oven dry litter mass remaining at time $\mathrm{t}$, and $\mathrm{N}_{0}=$ initial $\mathrm{N}$ content calculated on day 0 from the mean of all the drop bags in each of the three litter mix categories. C:N ratios were expressed in molar units. After the initial phase of leaching has occurred, relative change in $\% \mathrm{~N}$ remaining in small-mesh bags can serve as an indicator of microbially-mediated $\mathrm{N}$ dynamics. When microbial demand for $\mathrm{N}$ exceeds the $\mathrm{N}$ available from the litter substrate, microbes will transport and incorporate $\mathrm{N}$ from the soil, other litters, and throughfall. This results in a net accumulation of $\mathrm{N}$ (net $\mathrm{N}$ immobilization) inside the litterbags. $\% \mathrm{~N}$ remaining will exceed $100 \%$ of initial content while mass remaining decreases (Aber and Melillo 1980; Staaf 1980a, b). When $\mathrm{N}$ availability surpasses microbial demand, there is a net release of $\mathrm{N}$ (net mineralization) from the litterbags and \% N remaining will fall below 100\% (Berg and Staff 1981). Coupled with the greater respiratory loss of $\mathrm{C}$ relative to $\mathrm{N}$ loss, this also leads to concomitant decreases in the $\mathrm{C}: \mathrm{N}$ ratio during the early stages of decomposition (Staaf 1980a, b; Moore et al. 2006). This process proceeds until the later stages of 
decomposition, at which time the litter consists mostly of recalcitrant materials (Moore et al. 2006). While this method did not allow me to determine the fate of released $\mathrm{N}$, it is possible to determine whether $\mathrm{N}$ is being made available for plant uptake or whether it is being sequestered by the microbial community. In large-mesh bags where macroinvertebrates have access to the litter but do not remain in the bags, litter and $\mathrm{N}$ loss from the bags is assumed to be consumed by the invertebrates. The $\mathrm{N}$ consumed by macroinvertebrates may then be partitioned into assimilation, respiration, and fecal and excretory losses. $\mathrm{N}$ that is partitioned into fecal and excretory loss has the potential to be becoming potentially available to plants as well.

\section{Data Analysis}

A one-way ANOVA (proc ANOVA, SAS software 9.3, SAS Institute, Inc.) was used to determine statistical differences between initial litter chemistry $(\% \mathrm{~N}, \mathrm{C}: \mathrm{N})$ of honeysuckle, mixed, and sugar maple leaf litters. Post hoc comparisons were made using the Tukey HSD test. Mixed-model ANOVAs (PROC MIXED; SAS software 9.3, SAS Institute, Inc., Cary, NC) were used to determine statistical differences in percent leaf litter mass remaining, percent $\mathrm{N}$ remaining, $\mathrm{N}$ concentration $\left(\mathrm{mg} \mathrm{N} \mathrm{g}^{-1}\right.$ litter), and litter C:N. Litter type, mesh bag size, honeysuckle presence/removal, and their interactions served as fixed effects in the models, while site $(n=5)$ was used as a random effect. Planned comparisons were made between honeysuckle present and removed plots for each litter x mesh treatment (e.g. comparison between large-mesh sugar maple bags in honeysuckle present versus removed plots). A second set of comparisons were made between large-mesh and small-mesh bags for each litter $\mathrm{x}$ honeysuckle shrub treatment 
(e.g. comparison between large-mesh and small-mesh honeysuckle bags within honeysuckle present plots). Arcsine and $\log (\mathrm{x})$ transformations were performed as necessary to meet the assumptions of normality and homoscedasticity.

For the mixed litter portion of the experiment, I compared predicted and actual values using methods described in Gartner and Cardon (2004). If litters are assumed to decompose independently of one another in the mixed bag, then a predicted value may be calculated for the mixture using the following equation:

$$
\mathrm{V}_{\mathrm{P}}=0.85\left(\mathrm{~V}_{\mathrm{SM}}\right)+0.15\left(\mathrm{~V}_{\mathrm{HS}}\right)
$$

where $\mathrm{V}_{\mathrm{P}}$ is the predicted value for the mixed bag; $0.85\left(\mathrm{~V}_{\mathrm{SM}}\right)$ is the observed value obtained from a pure sugar maple bag in the same experimental block multiplied by its proportion in the mixed bag ( $85 \%$ in this case); and $0.15\left(\mathrm{~V}_{\mathrm{HS}}\right)$ is the observed value obtained from a pure honeysuckle bag in the same experimental block multiplied by its proportion in the mixed bag ( $15 \%$ in this case). The "value" portion of the equation represents percent mass remaining, percent $\mathrm{N}$ remaining, $\mathrm{N}$ concentration $\left(\mathrm{mg} \mathrm{N} \mathrm{g}^{-1}\right.$ litter), or litter $\mathrm{C}: \mathrm{N}$. If predicted values match observed values for the mixed litter bag, then the litters are decomposing independently of one another and the effects of mixing can be described as "additive". If predicted values do not match the observed values, then the effects of mixing may be described as "synergistic" (observed values are greater than predicted) or "antagonistic" (observed values are less than predicted). Differences between predicted and actual values were tested separately using paired t-tests (PROC TTEST, SAS software 9.3) for each mesh size and plot type (shrub present or removed) to determine if mixing effects were additive or not. 


\section{$\underline{\text { Results }}$}

\section{Initial Litter Chemistry}

As expected, the initial leaf litter chemistry of the three litter types differed in terms of $\mathrm{N}$ concentration $\left(F_{2,6}=422.21, p<0.0001\right)$ and their $\mathrm{C}: \mathrm{N}$ ratios $\left(F_{2,6}=1704.43\right.$, $p<0.0001)$. Post hoc comparisons using the Tukey HSD test indicated honeysuckle, sugar maple, and the mixed litter treatment differed significantly $(p \leq 0.05)$ from one another in terms of their initial mean $\mathrm{N}$ concentration and $\mathrm{C}: \mathrm{N}$ ratios. The predicted starting value for $\mathrm{N}$ concentration in the mixed litter treatment $\left(8.35 \mathrm{mg} \mathrm{N} \mathrm{g}^{-1}\right)$ was close to actual starting values $\left(8.5 \mathrm{mg} \mathrm{N} \mathrm{g}^{-1}\right)$. Similarly, the predicted starting value for the mixed litter $\mathrm{C}: \mathrm{N}$ ratio (61.42 $\mathrm{mg} \mathrm{N} \mathrm{g}^{-1}$ ) was similar to the actual starting $\mathrm{C}: \mathrm{N}$ ratio $\left(61.19 \mathrm{mg} \mathrm{N} \mathrm{g}^{-1}\right)$. My estimates for honeysuckle and sugar maple were similar to those reported by Trammell et al. (2012) for honeysuckle and sugar maple in this region.

\section{Mass Remaining}

No soil macroinvertebrates were observed within small mesh bags during the experiment, suggesting that the choice of mesh size was effective at excluding macroinvertebrates. Table 3.2 summarizes the mass remaining results observed in this study. As expected, large-mesh bags that permitted macroinvertebrate access contained less litter mass than small-mesh bags that excluded them (mesh size, $F_{1,44}=256.35$, $p<0.0001)$ and honeysuckle litter lost more mass than sugar maple litter (litter type, $\left.F_{2,44}=276.06, p<0.0001\right)$. However, the magnitude of the mesh size effect varied depending on the litter type used (mesh $\mathrm{x}$ litter, $F_{2,44}=38.53, p<0.0001$ ). Small-mesh honeysuckle bags retained 2.3 times more litter than large-mesh honeysuckle bags while 
small-mesh sugar maple bags only retained slightly more litter than their large mesh-bag counterparts (Fig 3.1). When comparing across litter types, sugar maple bags retained 1.3 and 2.7 times more litter than honeysuckle bags for the small-mesh and large-mesh treatments, respectively. Honeysuckle presence did not appear to influence litter mass

remaining by itself (honeysuckle shrubs, $F_{1,44}=0.54, p<0.47$ ), but it was found to interact with the mesh size treatment (mesh $\mathrm{x}$ honeysuckle shrub, $F_{1,44}=4.32, p<0.044$ ). Smallmesh bags tended to have more litter mass remaining where honeysuckle shrubs were present while large-mesh bags tended to have more mass remaining in honeysuckle removal plots.

Compared to the single honeysuckle and maple litters, the mixed litter treatment was intermediate for the effect of mesh size on mass remaining. Small-mesh mixed litter bags retained 1.3 times more litter than large-mesh mixed litter bags. Furthermore, the mixed-litter bags displayed synergistic mass loss patterns (Table 3.3). Large-mesh mixed bags contained $12.9 \%$ less litter mass than predicted $(t(9)=8.67, p=0.0001)$, while small mesh bags had $4.7 \%$ less mass than predicted $(t(9)=4.99, p=0.0008)$.

\section{$\%$ mass remaining}

Generally, trends in \% $\mathrm{N}$ mass remaining paralleled those observed for \% litter mass remaining (Table 3.2). Honeysuckle litter had less $\% \mathrm{~N}$ mass remaining than sugar maple litter (litter type, $F_{2,44}=101.20, p<0.0001$ ) and large-mesh bags that allowed macroinvertebrate access had less $\% \mathrm{~N}$ mass remaining than small-mesh bags that restricted soil macroinvertebrates (mesh size, $\left.F_{1,44}=259.02, p<0.0001\right)$. I observed a significant interaction between mesh size and litter type $\left(F_{2,44}=76.40, p<0.0001\right)$, 
indicating that the differences observed between the large-mesh and small-mesh bags varied depending on the litter treatment. Honeysuckle bags displayed the largest difference in $\% \mathrm{~N}$ remaining between mesh sizes, with small-mesh bags retaining 2.6 times more $\mathrm{N}$ than large-mesh bags. Conversely, no contrasts in $\% \mathrm{~N}$ remaining were observed between small-mesh and large-mesh sugar maple bags (Fig 3.2 a,d). Like mass remaining, honeysuckle shrubs did not appear to influence patterns observed for $\% \mathrm{~N}$ remaining $\left(F_{1,44}=0.48, p<0.49\right)$.

Patterns of $\% \mathrm{~N}$ mass remaining in the mixed litter treatment differed between the mesh sizes (Fig 3.2 a,d). Large-mesh mixed litter bags experienced a net loss of $\mathrm{N}(\bar{x}$ $=74.4 \% \mathrm{~N}$ remaining) while small-mesh mixed litter bags displayed a net gain of $\mathrm{N}(\bar{x}$ $=106.4 \% \mathrm{~N}$ remaining). Predicted values for $\% \mathrm{~N}$ remaining in mixed litter bags differed significantly from observed values. Large mesh bags contained $15.8 \%$ less $\mathrm{N}$ than predicted $(t(9)=9.29, p=0.0001)$ while small mesh bags had $6.2 \%$ more $\mathrm{N}$ than predicted $(t(9)=-4.06, p=0.003)$ based on calculations of the single litters decaying independently (Table 3.3).

\section{N concentrations}

As is often observed for decaying litter, $\mathrm{N}$ concentrations (expressed as $\mathrm{mg} \mathrm{N} \mathrm{g}^{-1}$ litter) for all three litter types increased over initial values after the 46 day field incubation (Table 3.2). The increase in $\mathrm{N}$ concentration in honeysuckle was greater than the increase observed for sugar maple (litter type, $F_{2,44}=723.69, p<0.0001$ ) and $\mathrm{N}$ concentration tended to be higher in small-mesh bags versus large-mesh bags (mesh size, $\left.F_{1,44}=30.21, p<0.0001\right)$. However, the magnitude of these increases differed depending 
on the litter type involved and whether macroinvertebrates could access the litter (mesh $\mathrm{x}$ litter interaction, $F_{2,44}=18.60$, $\left.p<0.0001\right)$. $\mathrm{N}$ concentrations were $3.6 \%$ lower in smallmesh bags compared to large-mesh bags for sugar maple. Conversely, honeysuckle litter in small-mesh bags had $\mathrm{N}$ concentrations that were $11.6 \%$ higher than those in largemesh bags (Fig 3.2 b,e). Though not significant at the $p \leq 0.05$ level, litter in honeysuckle removed plots displayed a trend towards having lower litter $\mathrm{N}$ concentrations than litter in honeysuckle present plots $\left(F_{1,44}=3.45, p<0.070\right)$.

$\mathrm{N}$ concentrations in the mixed litter treatment depended on whether macroinvertebrates could access the litter (Fig 3.2 b,e). Small-mesh mixed litter bags that restricted macroinvertebrate access had $11.3 \%$ higher $\mathrm{N}$ concentrations than their largemesh mixed bag counterparts that allowed macroinvertebrate access. Differences between observed and predicted $\mathrm{N}$ concentrations for the mixed litter treatment also depended on the mesh size treatment (Table 3.3). N concentration for mixed litter in small-mesh bags was $10.8 \%$ higher than predicted $(t(9)=-7.79, p=0.0001)$. However, no difference between observed and predicted values for $\mathrm{N}$ concentration were found in the large-mesh bags $(t(9)=0.46, p=0.66)$.

\section{C:N ratios}

As is typically observed, C:N ratios decreased from initial values for all litters over the 46 day period (Table 3.2). C:N ratios did not differ between honeysuckle present and removed plots $\left(F_{1,44}=0.83, p<0.37\right)$. The ability of macroinvertebrates to access litter inside the bags (mesh size, $F_{1,44}=12.76, p<0.0009$ ) and the identity of the litter present inside the bag (litter type, $F_{2,44}=530.20, p<0.0001$ ) were both found to be 
important in determining the $\mathrm{C}: \mathrm{N}$ ratio. $\mathrm{C}: \mathrm{N}$ ratios in large-mesh and small-mesh bags decreased by $24.7 \%$ and $32.1 \%$ for honeysuckle litter and $18.3 \%$ and $15.4 \%$ for sugar maple, respectively (Fig $3.2 \mathrm{c}, \mathrm{f}$ ). However, the direction and magnitude of these differences depended on the interaction between the mesh size and litter type treatments $\left(F_{2,44}=12.18, p<0.0001\right)$. The $\mathrm{C}: \mathrm{N}$ ratio of large-mesh honeysuckle bags was $10.2 \%$ higher than that of small-mesh honeysuckle bags $(p=0.009)$. Conversely, the $\mathrm{C}: \mathrm{N}$ ratio of large-mesh maple bags was 3.5\% lower than those observed for small mesh bags $(p=0.091)$.

C:N ratios in the mixed litter treatment declined $20.3 \%$ and $29.6 \%$ from starting values for large-mesh and small-mesh bags, respectively. This resulted in the C:N ratio of mixed litter being $12.5 \%$ higher in bags that allow macroinvertebrate access. Differences between observed and predicted C:N values also depended on mesh size (Table 3.3). Observed C:N ratios were only $2.0 \%$ lower than predicted in large-mesh mixed litter bags, resulting in no statistical differences between observed and predicted values $((t(9)=1.26, p=0.24)$. Conversely, observed C:N ratios in the small-mesh mixed litter bags were 16.8/\% lower than predicted $(t(9)=8.86, p=0.0001)$.

\section{$\underline{\text { Discussion }}$}

\section{Effects of mixing}

The results from this study suggest that when macroinvertebrates are excluded, honeysuckle litter may accelerate the decomposition and nutrient dynamics of native sugar maple litter in a synergistic manner. In bags that restricted macroinvertebrate access (i.e. small-mesh), the observed patterns for the sugar maple-honeysuckle mixture 
did not match predictions based on the component litters decomposing independently (Table 3.3). Small-mesh mixed litter bags lost significantly more litter mass and gained significantly more $\mathrm{N}$ than predicted, resulting in net immobilization of $\mathrm{N}$ (Fig. 3.2.a,d). The C:N ratio of litter inside the small-mesh mixed litter bags was also found to be significantly lower than predicted (Table 3.3). Because litter inside the small-mesh bags was not subject to macroinvertebrate consumption, labile $\mathrm{N}$ from honeysuckle litter could have had the time to prime the growth of the microbial community on the sugar maple litter below, allowing them to immobilize more $\mathrm{N}$ from external sources during the late winter to early spring period (e.g. from soil and surrounding litter, atmospheric deposition) (Paul and Clark 1989; Carreiro et al. 2000; Frey et al. 2000). Therefore, N released from decomposing honeysuckle litter in small-mesh bags may be immobilized by microbial communities on the underlying sugar maple litter, resulting in higher $\mathrm{N}$ concentrations and lower $\mathrm{C}: \mathrm{N}$ ratios I observed in the litter mixture.

These results agreed and conflicted with the results reported by Poulette and Arthur (2012). Similar to results for $\% \mathrm{~N}$ remaining for this experiment, Poulette and Arthur (2012) reported that mixtures of honeysuckle and native tree species $(F$. quadrangulata, Q. muehlenbergii, and C. ovata) in small-mesh $(1 \mathrm{x} 1 \mathrm{~mm})$ bags resulted in synergistic $\mathrm{N}$ losses. It should be noted that these results agreed despite the different ratios used in each study (i.e. $85 \%$ sugar maple to $15 \%$ honeysuckle in my study; $1: 1$ ratio of native tree to honeysuckle in the other). However, contrary to results for mass remaining in this study, Poulette and Arthur (2012) found no synergistic or antagonistic mass loss effects in 1:1 honeysuckle to native tree litter mixtures. One possible explanation for these conflicting results is that differences in litter chemistry among 
different litter species may regulate the effects of honeysuckle litter on decomposition. Inhibitory secondary compounds such as tannins and other polyphenols can alter decomposition dynamics of litters (Horner et al. 1988; Hättenschwiler and Vitousek 2000) and differences in the types and amounts of these compounds may have varied between the sugar maple litter used in this study and the litters used by Poulette and Arthur (2012).

\section{Effects of shrub honeysuckle}

I did not observe a honeysuckle shrub presence/absence effect on mass remaining or $\mathrm{N}$ gain/loss patterns in this study. If the effect of honeysuckle shrub presence on litter decomposition is related to the shrub canopy (e.g. shade, throughfall chemistry), then the lack of a honeysuckle shrub effect may have been caused by the timing and duration of the study. Bud break for shrub honeysuckles was noted to have begun at approximately the same time litter bags were deployed in the field (February 17, 2013); however, the shrub canopy was incomplete during the first four to five weeks of this study depending on the site (Pipal, personal observation). Thus, the litter bags spent most of the incubation period under an incomplete shrub canopy and any effects of honeysuckle presence aboveground may have been reduced. Alternatively, soil legacies from past honeysuckle shrub colonization, if they occurred, may not have had time to dissipate in four years. Despite the absence of a honeysuckle shrub effect, a significant mesh size x honeysuckle shrub interaction was observed for litter mass remaining. Large-mesh bags tended to have less mass remaining in honeysuckle shrub present plots compared to 
honeysuckle removal plots. This suggests that honeysuckle shrub presence may increase the size and/or feeding activity of macroinvertebrate detrivore populations.

Previous studies on decomposition under versus not under honeysuckle shrubs have produced mixed results. Trammell et al. (2012) reported that sugar maple litter in urban highway verge forests in Louisville decayed 19\% more quickly in areas with high shrub density compared to areas with low shrub density. However, these locations were confounded with proximity to the city (higher shrub density closer to the city) where other factors, such as warmer temperatures, could have contributed to these results. Conversely, Arthur et al. (2012) found slower decomposition rates for white ash (Fraxinus americana) and hickory (Carya spp.) litter incubated under honeysuckle shrubs versus away from honeysuckle in a secondary forest in central Kentucky.

\section{Effects of macroinvertebrates}

The results of this study suggest that soil macroinverebrates may preferentially feed on high quality honeysuckle litter during the late winter to early spring period (Fig 3.1). While large differences were observed between mesh sizes for both mass and net $\mathrm{N}$ loss (Fig 3.1; Fig 3.2), the magnitude of these differences varied considerably between litter types. Unsurprisingly, mass loss rates and $\mathrm{N}$ dynamics of high quality honeysuckle litter was more sensitive to mesh size than native sugar maple, whose initial chemistry (high C:N, lower \%N, higher \% lignin than sugar maple) would predict slower rates of decay. Because macroinvertebrate detritivores are known to preferentially feed on higher quality litters (Hendrikson 1990; Schädler and Brandl 2005), difference in mass loss and $\mathrm{N}$ loss between mesh sizes and between large-mesh honeysuckle and maple bags are 
likely due to macroinvertebrate activity. I am aware that large-mesh bags could have lost litter at a disproportionately higher rate than small mesh bags due to fragmentation and/or to differences in the friability of honeysuckle and sugar maple litter. While I attempted to correct for this by collecting any identifiable honeysuckle or sugar maple fragments beneath the litter bags, it should be noted that fragmentation is part of the catabolic degradation of litter (Anderson 1973) and that the movement of litter fragments into the soil is a functional role of detritivore fauna and part of the decomposition process (Bradford et al. 2002).

Selectivity by macroinvertebrates can have implications for mass loss and the timing of $\mathrm{N}$ release when litters of contrasting qualities are mixed together. As mentioned previously, observed patterns for mass and nitrogen loss in small-mesh mixed bags did not match the predictions made based on the component litters decomposing independently (Table 3.3). However, different patterns emerged when macroinvertebrates were permitted access to the mixed litter treatment. While both mesh sizes lost significantly more litter mass than predicted, the difference between observed and predicted values in large-mesh mixed bags was 2.7 times greater than the difference in small-mesh mixed bags. Macroinvertebrates entering the large-mesh bags to feed on honeysuckle litter may have also increased fragmentation losses for sugar maple litter in the process. In terms of $\mathrm{N}$ dynamics, large-mesh mixed bags had significantly less $\% \mathrm{~N}$ remaining than predicted, but no differences were found between observed and predicted values for $\mathrm{N}$ concentrations or the $\mathrm{C}: \mathrm{N}$ ratio. These results suggest that the selective and rapid removal of honeysuckle litter by macroinvertebrates may disrupt the synergistic interactions observed in the small-mesh mixed bags that lead to net $\mathrm{N}$ immobilization. As 
a result, $\mathrm{N}$ mineralization occurs. It should be noted that this study involved only two litter species and that honeysuckle and sugar maple leaf litter differ greatly in terms of quality (see Trammell et al. 2012). It is possible that the magnitude and directionality of the "macroinvertebrate effect" may change depending on the number and identity of component litters used in the mixture and their degree of nutrient and phenolic contrast (Schädler and Brandl 2005; Holdsworth et al. 2012).

\section{Revisiting the honeysuckle-litter feedback model}

While this study did not directly examine the proposed feedback loop outlined by Trammell et al. (2012) by determining if the shrub utilized the $\mathrm{N}$ released from the litter, the results presented here suggest that the creation of an early season nutrient pulse may be enhanced by or actually result from selective feeding by macroinvertebrate. This study showed that macroinvertebrate detritivores were actively consuming leaf litter during the late winter to early spring time period and that they greatly enhanced the speed of honeysuckle decomposition and net $\mathrm{N}$ export from the litter layer to the soil and soil macrobiota. While I prefer to use the more general term "soil macroinvertebrate detritivore", a companion study found large populations of invasive, Eurasian earthworms at all of the sites used for this experiment (Chapter 1). Lumbricus terrestris, a Eurasian species that constructs deep, vertical burrows and feeds on surface litter (Bouché 1977), was the most important species in terms of biomass during the late winter-early spring period at these sites.

This study did not quantify how much of the early spring $\mathrm{N}$ losses from the litter bags were partitioned between worm assimilation, worm cast formation, worm excretion, 
and meiofaunal and microbial uptake. Each of these processes would release plantavailable $\mathrm{N}$ with different time lags. However, some estimates can be made. Nitrogen assimilation efficiencies for $L$. terrestris range from $25.4 \%$ to $30.1 \%$ of ingested $\mathrm{N}$ (Whalen and Parmelee 1999). Nitrogen excretory rates for L. terrestris have been measured in two ways. The first method involves placing fasting earthworms in flasks containing a small volume of water and analyzing the $\mathrm{N}$ content of the water after 24 hours. Studies using this method have been reported nitrogen excretory rates to range from 60 to $269 \mu \mathrm{g} \mathrm{N} \mathrm{g}^{-1}$ (worm fresh weight) day ${ }^{-1}$ (Needham 1957; Tillinghast (1967). Of the nitrogen excreted by L. terrestris in the Needham (1957) study, $20.1 \%$ was in the form of ammonia, $15.2 \%$ was in the form of urea, and $64.7 \%$ was in the form of "residual nitrogen" (i.e. proteins, probably from mucus). More recently excretion rates for $L$. terrestris adults have been estimated using stable isotope analysis $\left({ }^{15} \mathrm{~N}\right)$ (Whalen et al. 2000). In this study, nitrogen excretion rates for $L$. terrestris adults were found to be $531.9 \mu \mathrm{g} \mathrm{N} \mathrm{g}^{-1}$ (worm fresh weight) day ${ }^{-1}$. Earthworms in the Whalen et al. (2000) study were fed soybean leaves (C:N ratio of 12) whereas earthworms in the Needham (1957) study were raised on elm leaves (C:N not reported, but based on Polyakova and Billor (2007) for Ulmus americana would likely have been closer to 46). One possible explanation for the wide range in reported nitrogen excretion rates is that earthworms may conserve tissue $\mathrm{N}$ when $\mathrm{N}$ resources are low (e.g. when worms are fed litters that are low in $\mathrm{N}$ ). Conversely, when $\mathrm{N}$ resources are plentiful (e.g. when worms are fed litters rich in N), excretion rates may be higher as earthworms are less concerned with conserving tissue $\mathrm{N}$ (Whalen et al. 2000). Given the leaf chemistry difference between honeysuckle and sugar maple litter (Table 3.2), earthworms feeding on honeysuckle litter 
may have higher $\mathrm{N}$ excretory rates than those feeding on more recalcitrant sugar maple litter. Castings and other deposits from these species can greatly enhance soil microbial activity and N mineralization rates within the drilosphere (Burtelow et al. 1998; Parkin and Berry 1999; Zhu and Carreiro 2004).

\section{Conclusion}

This study examined the importance of litter mixing and soil macroinvertebrate detritivore activity in creating a potential feedback that could promote the growth of invasive honeysuckle shrubs. Mixing honeysuckle and sugar maple litter produced nonadditive effects on patterns of mass and $\mathrm{N}$ loss; however, the magnitude and direction of these effects were modulated by the activity of soil macroinvertebrates. When macroinvertebrates were excluded, mixed litter had more mass loss than predicted and net $\mathrm{N}$ immobilization occurred. Conversely, litter mass losses were much larger when macroinvertebrates were allowed to access litter and net $\mathrm{N}$ mineralization occurred. This suggests that macroinvertebrates negate interactions between honeysuckle and sugar maple litters, potentially by preferentially feeding on and removing honeysuckle litter. This suggests that macroinvertebrates may 1) play an important role in regulating interactions between invasive and native litters, particularly if they are of contrasting litter quality, and 2) create an early season nitrogen pool in forests that honeysuckle and

other invasive plants with earlier leaf-out phenologies than native plants can benefit from. Therefore, future leaf litter decomposition research should consider both the effects of mixing litter and the potential impacts of macroinvertebrate detritivores on litter 
interactions to generate more realistic models for decomposition and the timing of nutrient release in invaded forests. 
Table 3.1. Study site locations for litterbag nutrient study. $\mathrm{H}=$ honeysuckle shrubs present, $\mathrm{R}=$ honeysuckle shrubs removed. Stem density is expressed as stems per hectare while basal area is expressed as $\mathrm{m}^{2}$ per hectare. The "other exotic shrub" category includes all exotic shrubs except shrub honeysuckle. No native shrubs occurred in these plots.

\begin{tabular}{|c|c|c|c|c|c|c|c|}
\hline Site & $\begin{array}{l}\text { Coordinates } \\
\text { (dd) }\end{array}$ & $\begin{array}{l}\text { Depth to } \\
\text { Bedrock } \\
\text { (cm) }\end{array}$ & $\begin{array}{l}\text { Honeysuckle } \\
\text { Stem Density } \\
\quad \text { (\# / ha) }\end{array}$ & $\begin{array}{c}\text { Honeysuckle } \\
\text { Basal Area } \\
\left(\mathrm{m}^{2} / \mathrm{ha}\right)\end{array}$ & $\begin{array}{c}\text { Other Exotic Shrub } \\
\text { Stem Density } \\
\text { (\# / ha) }\end{array}$ & $\begin{array}{c}\text { Other Exotic Shrub } \\
\text { Basal Area } \\
\left(\mathrm{m}^{2} / \mathrm{ha}\right)\end{array}$ & $\begin{array}{c}\text { Aspect } \\
\left(0^{\circ}=\text { North }\right)\end{array}$ \\
\hline $2-\mathrm{H}$ & $38.243 ;-85.700$ & 87 & 10,700 & 7.98 & 0 & 0.00 & $\mathrm{~S}\left(158^{\circ}\right)$ \\
\hline $2-\mathrm{R}$ & $38.243 ;-85.700$ & 87 & 700 & 0.10 & 0 & 0.00 & $\operatorname{SE}\left(148^{\circ}\right)$ \\
\hline $3-\mathrm{H}$ & $38.245 ;-85.696$ & $>122$ & 14,100 & 6.15 & 500 & 0.05 & $\mathrm{~W}\left(271^{\circ}\right)$ \\
\hline $3-\mathrm{R}$ & $38.245 ;-85.696$ & $>122$ & 3,200 & 0.12 & 500 & 0.06 & $\mathrm{~W}\left(271^{\circ}\right)$ \\
\hline $4-\mathrm{H}$ & $38.242 ;-85.696$ & 92 & 12,800 & 8.15 & 0 & 0.00 & $\operatorname{SE}\left(149^{\circ}\right)$ \\
\hline $4-\mathrm{R}$ & $38.242 ;-85.696$ & 92 & 100 & 0.00 & 200 & 0.07 & $\mathrm{~S}\left(158^{\circ}\right)$ \\
\hline $6-\mathrm{H}$ & $38.240 ;-85.694$ & $>122$ & 14,400 & 2.93 & 3,900 & 0.50 & $\mathrm{~W}\left(252^{\circ}\right)$ \\
\hline $6-\mathrm{R}$ & $38.240 ;-85.694$ & $>122$ & 1,700 & 0.07 & 30,500 & 1.84 & $\mathrm{~W}\left(277^{\circ}\right)$ \\
\hline $8-\mathrm{H}$ & $38.234 ;-85.684$ & 58 & 17,700 & 8.38 & 0 & 0.00 & $\mathrm{~W}\left(259^{\circ}\right)$ \\
\hline $8-\mathrm{R}$ & $38.234 ;-85.684$ & 58 & 1,200 & 0.18 & 0 & 0.00 & $\mathrm{~W}\left(253^{\circ}\right)$ \\
\hline
\end{tabular}


Table 3.2. Initial and subsequent $\mathrm{N}$ concentration and $\mathrm{C}: \mathrm{N}$ ratios of leaf litter and their mass remaining after 46 days in late winter to early spring. Litters were placed in either small $(1 \mathrm{~mm})$ or large $(10 \mathrm{~mm})$ mesh bags and set out in plots where honeysuckle shrubs were present or had been removed 4 years prior. The differences between values in small vs. large mesh bags reflect the effects of macroinvertebrates on litter quality, mass loss and $\mathrm{N}$ dynamics during decomposition of the three litter types. Values are means; parentheses enclose standard errors $(n=5)$. Different letters in rows indicate a significant difference $(\mathrm{p} \leq 0.05)$ between large mesh and small mesh bags for a given litter and plot type, according to analyses of variance. No differences were observed between shrub present and shrub removed plots.

\begin{tabular}{|c|c|c|c|c|c|c|c|c|c|c|}
\hline & \multicolumn{2}{|c|}{ Initial } & \multicolumn{2}{|c|}{$\%$ Mass Remaining } & \multicolumn{2}{|c|}{$\%$ N Mass Remaining } & \multicolumn{2}{|c|}{$\mathrm{N}$ Conc. $\left(\mathrm{mg} \mathrm{N} \mathrm{g}^{-1}\right)$} & \multicolumn{2}{|c|}{$\mathrm{C}: \mathrm{N}$} \\
\hline & $\underset{1}{\mathrm{mg} \mathrm{N}^{-}}$ & $\mathrm{C}: \mathrm{N}$ & $\begin{array}{l}\text { Large } \\
\text { Mesh }\end{array}$ & $\begin{array}{l}\text { Small } \\
\text { Mesh }\end{array}$ & $\begin{array}{l}\text { Large } \\
\text { Mesh }\end{array}$ & $\begin{array}{l}\text { Small } \\
\text { Mesh }\end{array}$ & $\begin{array}{l}\text { Large } \\
\text { Mesh }\end{array}$ & $\begin{array}{l}\text { Small } \\
\text { Mesh }\end{array}$ & $\begin{array}{l}\text { Large } \\
\text { Mesh }\end{array}$ & $\begin{array}{l}\text { Small } \\
\text { Mesh }\end{array}$ \\
\hline \multicolumn{11}{|l|}{ Honeysuckle } \\
\hline Shrubs Present & 11.75 & 40.78 & $\begin{array}{l}30.83^{\mathrm{a}} \\
(6.070)\end{array}$ & $\begin{array}{l}76.62^{b} \\
(3.119)\end{array}$ & $\begin{array}{l}34.80^{\mathrm{a}} \\
(6.248)\end{array}$ & $\begin{array}{l}96.27^{\mathrm{b}} \\
(3.933)\end{array}$ & $\begin{array}{l}13.18^{\mathrm{a}} \\
(0.181)\end{array}$ & $\begin{array}{l}14.66^{\mathrm{b}} \\
(0.200)\end{array}$ & $\begin{array}{l}31.19^{\mathrm{a}} \\
(0.789)\end{array}$ & $\begin{array}{l}27.60^{b} \\
(0.583)\end{array}$ \\
\hline Shrubs Removed & $(0.250)$ & $(0.710)$ & $\begin{array}{l}35.15^{\mathrm{a}} \\
(4.697)\end{array}$ & $\begin{array}{l}74.84^{\mathrm{b}} \\
(1.058)\end{array}$ & $\begin{array}{l}40.78^{\mathrm{a}} \\
(5.346)\end{array}$ & $\begin{array}{l}98.13^{\mathrm{b}} \\
(3.834)\end{array}$ & $\begin{array}{l}13.48^{\mathrm{a}} \\
(0.180)\end{array}$ & $\begin{array}{l}15.28^{\mathrm{b}} \\
(0.622)\end{array}$ & $\begin{array}{l}30.19^{\mathrm{a}} \\
(0.722)\end{array}$ & $\begin{array}{l}27.82^{\mathrm{a}} \\
(1.294)\end{array}$ \\
\hline \multicolumn{11}{|l|}{ Mixed } \\
\hline Shrubs Present & 8.50 & 61.19 & $\begin{array}{l}70.14^{\mathrm{a}} \\
(3.136)\end{array}$ & $\begin{array}{l}88.80^{b} \\
(0.599)\end{array}$ & $\begin{array}{l}74.23^{\mathrm{a}} \\
(2.849)\end{array}$ & $\begin{array}{l}106.75^{\mathrm{b}} \\
(1.708)\end{array}$ & $\begin{array}{c}8.96^{\mathrm{a}} \\
(0.235)\end{array}$ & $\begin{array}{l}10.15^{\mathrm{b}} \\
(0.120)\end{array}$ & $\begin{array}{l}49.94^{\mathrm{a}} \\
(1.254)\end{array}$ & $\begin{array}{l}43.39^{b} \\
(1.195)\end{array}$ \\
\hline Shrubs Removed & $(0.100)$ & $(0.170)$ & $\begin{array}{l}67.01^{\mathrm{a}} \\
(2.257)\end{array}$ & $\begin{array}{l}85.95^{\mathrm{b}} \\
(1.189)\end{array}$ & $\begin{array}{l}74.58^{\mathrm{a}} \\
(2.338)\end{array}$ & $\begin{array}{l}105.99^{\mathrm{b}} \\
(4.309)\end{array}$ & $\begin{array}{c}9.39^{\mathrm{a}} \\
(0.132)\end{array}$ & $\begin{array}{l}10.41^{\mathrm{b}} \\
(0.384)\end{array}$ & $\begin{array}{l}47.65^{\mathrm{a}} \\
(1.018)\end{array}$ & $\begin{array}{l}42.75^{b} \\
(1.761)\end{array}$ \\
\hline \multicolumn{11}{|l|}{ Sugar maple } \\
\hline Shrubs Present & 7.75 & 65.08 & $\begin{array}{l}88.47^{\mathrm{a}} \\
(1.376)\end{array}$ & $\begin{array}{l}96.18^{b} \\
(1.486)\end{array}$ & $\begin{array}{l}97.64^{\mathrm{a}} \\
(1.710)\end{array}$ & $\begin{array}{c}102.23^{\mathrm{a}} \\
(1.556)\end{array}$ & $\begin{array}{c}8.52^{\mathrm{a}} \\
(0.224)\end{array}$ & $\begin{array}{c}8.24^{\mathrm{a}} \\
(0.156)\end{array}$ & $\begin{array}{l}53.88^{\mathrm{a}} \\
(1.034)\end{array}$ & $\begin{array}{l}54.24^{\mathrm{a}} \\
(1.239)\end{array}$ \\
\hline Shrubs Removed & $(0.150)$ & $(0.605)$ & $\begin{array}{l}91.47^{\mathrm{a}} \\
(0.738) \\
\end{array}$ & $\begin{array}{l}93.71^{\mathrm{a}} \\
(0.350)\end{array}$ & $\begin{array}{c}101.17^{\mathrm{a}} \\
(1.637)\end{array}$ & $\begin{array}{l}99.20^{\mathrm{a}} \\
(2.806)\end{array}$ & $\begin{array}{c}8.52^{\mathrm{a}} \\
(0.108) \\
\end{array}$ & $\begin{array}{c}8.20^{\mathrm{a}} \\
(0.214) \\
\end{array}$ & $\begin{array}{l}52.47^{\mathrm{a}} \\
(1.094)\end{array}$ & $\begin{array}{l}55.86^{b} \\
(2.167)\end{array}$ \\
\hline
\end{tabular}


Table 3.3. Predicted versus actual values for the mixed leaf litter type in large and small mesh bags decaying over a 46 day period from late winter to early spring. Large mesh bags permitted entry of macroinvertebrates while small mesh bags did not. Thus the difference between large and small mesh bags reflects the impact of macroinvertebrates on these variables. Predicted values are those that would have been obtained had the honeysuckle and sugar maple litters in the mixed litter bags decayed independently without interaction. No significant differences were noted between shrub present and shrub removed plots, so data from both plot types were averaged for analysis. Values are means; parentheses enclose standard errors $(n=10)$. Asterisks denote statistical significance between actual and predicted values within a given mesh size using a paired t-test $(* * \mathrm{p}<0.01, * * * \mathrm{p}<0.0001)$.

\begin{tabular}{|c|c|c|c|c|c|}
\hline & \multicolumn{2}{|c|}{$\begin{array}{l}\text { Large Mesh } \\
(10 \mathrm{~mm})\end{array}$} & \multicolumn{3}{|c|}{$\begin{array}{l}\text { Small Mesh } \\
(1 \mathrm{~mm})\end{array}$} \\
\hline & \multicolumn{2}{|c|}{ Actual vs Predicted } & \multicolumn{3}{|c|}{ Actual vs Predicted } \\
\hline$\%$ Mass Remaining & $68.6(1.89)$ & vs $81.4(1.13)^{* * *}$ & $87.4(0.79)$ & vs & $92.1(0.75)^{* *}$ \\
\hline$\%$ N Mass Remaining & $74.4(1.74)$ & vs $90.2(1.10)^{* * * *}$ & $106.4(2.19)$ & vs & $100.2(1.48)^{* *}$ \\
\hline N (mg N / g litter) & $9.2(0.15)$ & vs $9.2(0.11)$ & $10.3(0.20)$ & vs & $9.2(0.14)^{* * *}$ \\
\hline Molar C:N & $49.9(1.25)$ & vs $50.5(0.92)$ & $43.4(1.20)$ & vs & $50.2(1.12)^{* * *}$ \\
\hline
\end{tabular}



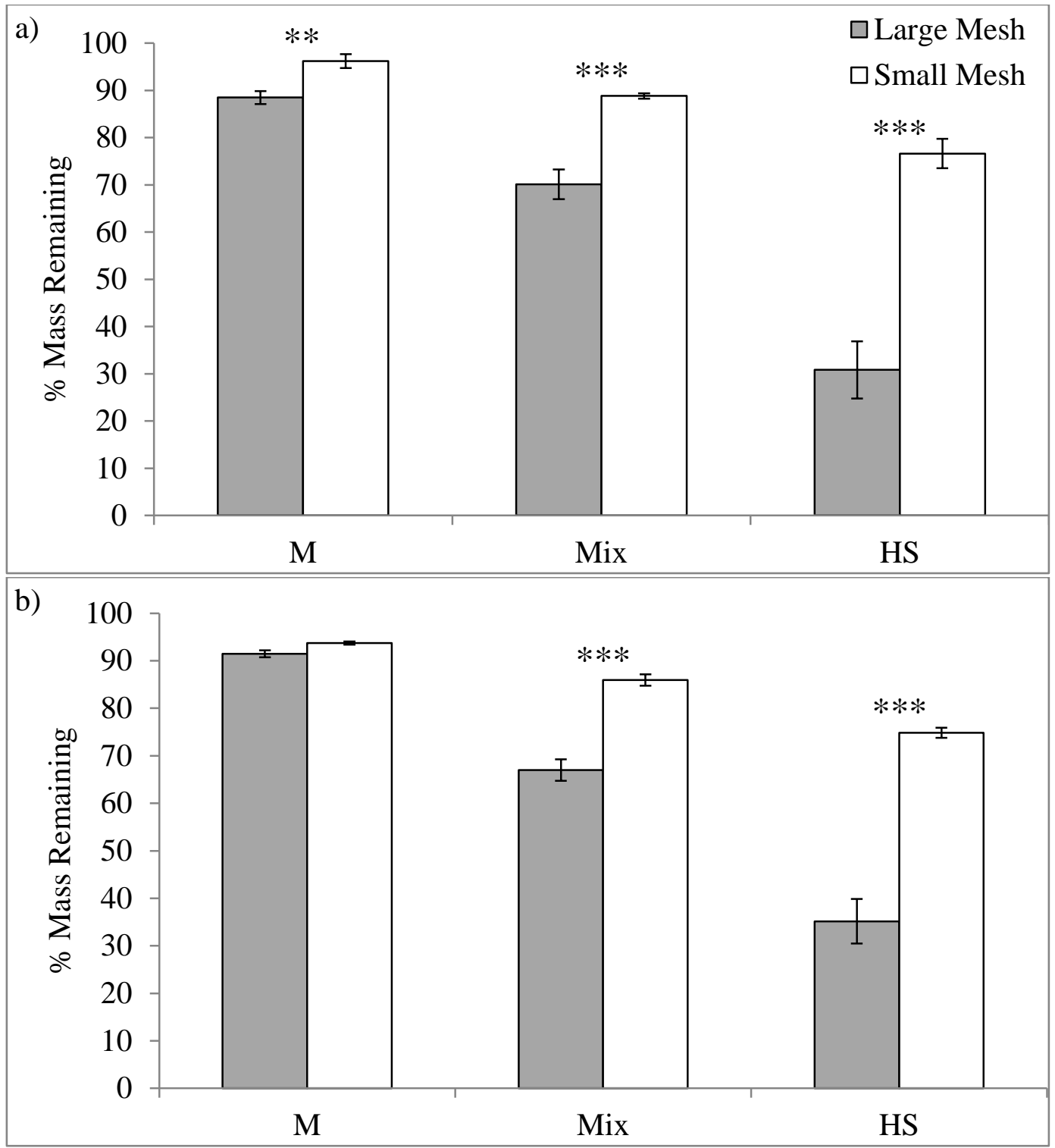

Figure 3.1. Mean percent mass remaining in honeysuckle shrub present (a) versus honeysuckle shrub removed (b) plots. $\mathrm{M}=$ maple, $\mathrm{Mix}=85 \%$ maple $+15 \%$ honeysuckle, $\mathrm{HS}=$ honeysuckle. Bars represent the mean $( \pm \mathrm{SE})$. Asterisks denote statistical significance between mesh sizes for a particular litter type $(*: \mathrm{p}<0.05, * *: \mathrm{p}<0.01, * * *$ : $\mathrm{p}<0.0001)$. No significant differences were noted between shrub present and shrub removed plots. 


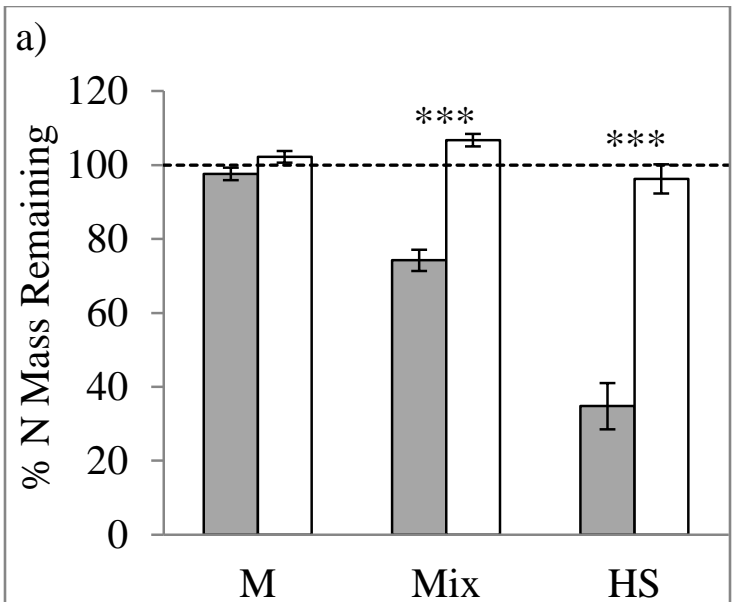

b)

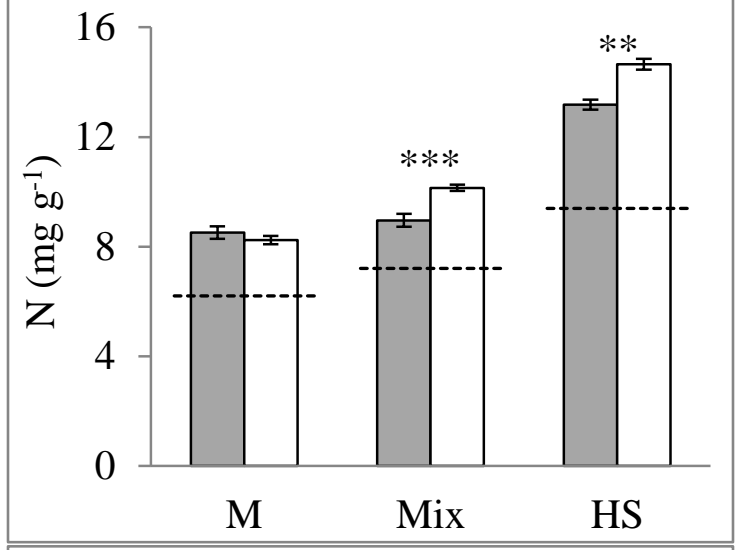

c)

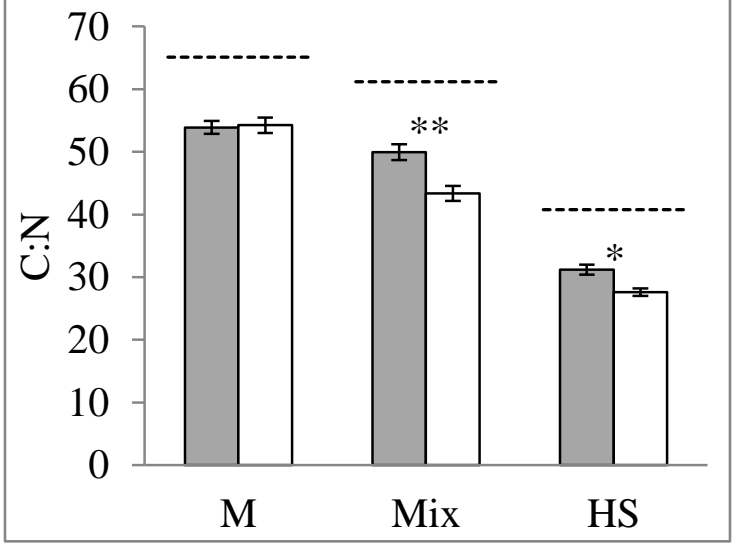

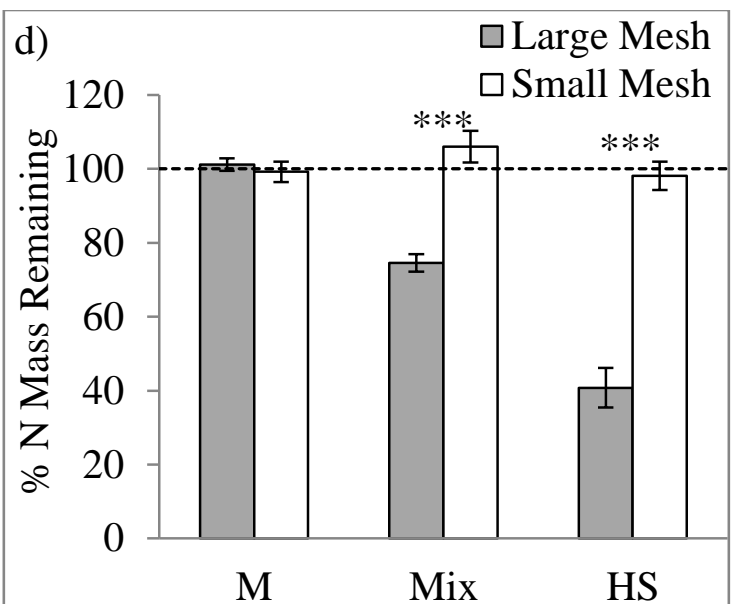

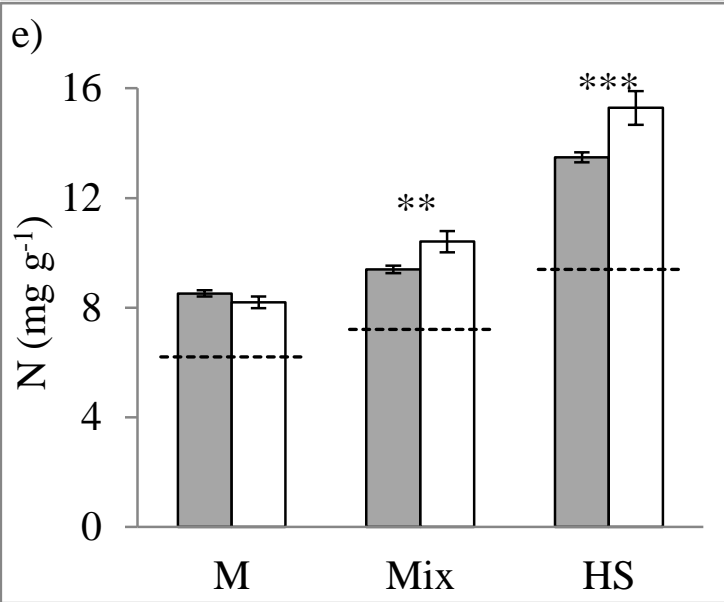

f)

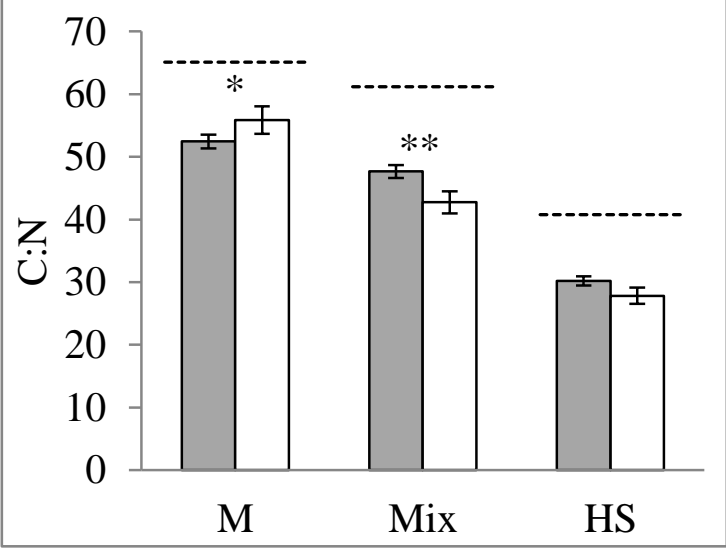

Figure 3.2. Changes in $\mathrm{N}$ mass remaining (\%), $\mathrm{N}$ concentration $\left(\mathrm{mg} \mathrm{N} \mathrm{g}^{-1}\right)$, and $\mathrm{C}: \mathrm{N}$ for shrub present $(\mathrm{a}, \mathrm{b}, \mathrm{c})$, and shrub removed (d, e, f) plots. $\mathrm{M}=$ maple, Mix $=85 \%$ maple + $15 \%$ honeysuckle, HS = honeysuckle. Bars represent the mean $( \pm \mathrm{SE})$. Horizontal dotted lines represent initial values. Asterisks denote statistical significance between mesh sizes for a particular litter type $(*: \mathrm{p}<0.05, * *: \mathrm{p}<0.01, * * *: \mathrm{p}<0.0001)$. 


\section{CHAPTER IV}

\section{SEASONAL SOIL NUTRIENT DYNAMICS OF A THREE-YEAR HONEYSUCKLE SHRUB REMOVAL CHRONOSEQUENCE IN URBAN FORESTS}

\section{$\underline{\text { Introduction }}$}

Next to habitat loss, invasive species represent one of the largest threats to biodiversity and the functioning and stability of ecosystems (Wilcove et al. 1998). Much of the research into exotic species invasion has focused on how invasion impacts the composition and structure of aboveground communities and its effects on the abundance and distribution of native species (Vitousek et al. 1997; Levine et al. 2003; Wolfe and Klironomos 2005). Over the last decade, however, greater emphasis has been placed on understanding how invasion influences interactions between above and belowground communities (Wardle et al. 2004; Bohlen 2006) and how these impacts affect leaf litter decomposition (Ashton et al. 2005; Trammell et al. 2012), soil nutrient cycling (Ehrenfeld et al. 2001; Evans et al. 2001; Ehrenfeld 2003; Liao et al. 2008), the structure and function of soil communities (Kourtev et al. 2002; Kourtev et al. 2003; Hawkes et al. 2005), and mycorrhizal-plant associations (Hawkes et al. 2006; Vogelsang and Bever 2009).

Understanding the impacts of invasion on soil nitrogen $(\mathrm{N})$, carbon $(\mathrm{C})$, and microbial biomass dynamics is of particular importance. $\mathrm{N}$ is often the limiting factor for 
plant growth and net primary productivity in temperate ecosystems (Chapin et al. 1986; Vitousek and Howarth 1991) and $\mathrm{N}$ tends to display strong seasonal patterns in terms of its availability (Butterbach-Bahl and Gundersen 2011). Plants tend to utilize inorganic forms of $\mathrm{N}$ (i.e. ammonium, nitrate) for growth in temperate ecosystems, with the highest rates of uptake occurring during the late spring and summer growing months (ButterbachBahl and Gundersen 2011). Soil microbes are almost entirely responsible for soil transformations of N (Hawkes et al. 2005; van der Heijden et al. 2008) and play an important role in N and C cycling (Zogg et al. 2000; Kowalchuk and Stephen 2001; Bardgett et al 2008). While plants and microbes may compete for inorganic $\mathrm{N}$ pools when $\mathrm{N}$ is limiting (Kaye and Hart 1997), mineralization of $\mathrm{N}$ by soil microbes is a crucial process which transforms $\mathrm{N}$ into plant-available forms (Butterbach-Bahl and Gundersen 2011). Though microbial biomass represents only 1-4\% of total soil C (Sparling 1992) and 2-6\% of total soil N (Brookes et al. 1985), it is among the most labile pools of nutrients in the soil (Jenkinson and Ladd 1981) and may serve as a readily responsive source or sink of $\mathrm{C}$ and $\mathrm{N}$ depending on the season and environmental conditions (Vitousek and Matson 1984; Groffman et al. 1993; Zak et al. 1990b).

In this study, I quantify the changes that occur in inorganic and organic nutrient pools of $\mathrm{C}$ and $\mathrm{N}$ following the removal of the invasive shrub Lonicera maackii (Amur honeysuckle) compared to locations containing this shrub to estimate the effect that honeysuckle colonization and subsequent management may have on these pools. Since its introduction to North America from Asia in 1896 (Luken and Thieret 1996), L. maackii has become established in 28 states in the United States (USDA NRCS 2014). An extended leaf phenology (Trisel and Gorchov 1994) and high allocation to reproduction 
(Ingold and Craycraft 1983) contribute to the shrub's ability to invade native ecosystems. Gap formation and canopy disturbance are important in facilitating the establishment of L. maackii populations in the forest interiors (Hutchinson and Vankat 1998) where dense thickets formed by the shrub can negatively affect the abundance, species richness, and regeneration of herbaceous and woody natives (Hutchinson and Vankat 1997; Collier et al 2002; Hartman and McCarthy 2004; Miller and Gorchov 2004). While L. maackii's effects on the above-ground forest community are well documented, little is known about how the shrub alters soil nutrient cycling or influences soil microbes. A study by Arthur et al. (2012) reported that microbial communities found on decaying honeysuckle leaf litter differed from those that colonized white ash (Fraxinus americana) and hickory (Carya spp.). Because the litter from shrub honeysuckle is of a higher quality (i.e. lower $\mathrm{C}: \mathrm{N}$ ratio, lower percent lignin, lower lignin: $\mathrm{N}$ ratio) compared to many native tree litters, these shrubs have the potential to alter decomposition and nutrient dynamics in invaded forests (Poulette and Arthur 2012; Trammell et al. 2012). Decomposition rates for honeysuckle litter have been reported to be three to five times faster than sugar maple (Acer saccharum), white ash (Fraxinus americana) and hickory (Carya spp) litters (Blair and Stowasser 2009; Arthur et al. 2012; Trammell et al. 2012) and up to 21 times faster than northern red oak (Quercus rubra) litter (Blair and Stowasser 2009). Shrub honeysuckle litter has also been reported to release nitrogen more rapidly than sugar maple, ash, oak, or hickory litters (Poulette and Arthur 2012; Trammell et al. 2012). However, no studies have examined the effects of L. maackii on nutrient or microbial biomass $\mathrm{C}$ and $\mathrm{N}$ pools in soils. 
Previous literature reviews have proposed that invasive plants species have the potential to drastically alter $\mathrm{C}$ and $\mathrm{N}$ dynamics in soils by changing the quality (e.g. $\mathrm{C}: \mathrm{N}$, lignin:N), quantity, and timing of leaf litter and root turnover/exudate inputs (Kourtev et al. 2002; Ehrenfeld 2003; Liao et al. 2008; Ehrenfeld 2010). Liao et al. (2008) reported that invaded ecosystems demonstrated higher decomposition rates (117\% increase), higher net $\mathrm{N}$ mineralization (52\% increase) and nitrification (53\% increase), and larger amounts of microbial biomass C (34\% increase) and microbial biomass N (26\% increase). Ehrenfeld (2003) found that plant invasion lead to increases in microbial biomass $\mathrm{N}$ in eight out of 10 cases, though no clear patterns were observed for microbial biomass $\mathrm{C}$ ( $\mathrm{n}=6$ studies). L. maackii litter has a significantly different leaf litter chemistry compared to native tree litters (Arthur et al 2012; Poulette and Arthur 2012; Trammell et al. 2012) and shrub honeysuckles can act as a barrier to senesced leaves from the forest overstory (McNeish et al. 2014). Furthermore, extended leaf phenology of L. maackii may permit these shrubs to utilize soil nutrient pools earlier in the season than other woody natives. For example, $25 \%$ to $35 \%$ of the annual carbon gain in Lonicera $x$ bella was reported to occur during the early spring before canopy emergence (Harrington et al. 1989). This may create a drawdown of inorganic nitrogen earlier in the season, reducing the availability of $\mathrm{N}$ to natives that leaf out later in the spring. Thus, L. maackii shrubs have the potential to alter soil nutrient and microbial biomass pools by changing a) the quality of litter inputs and/or b) the size of nutrient pools during different seasons.

The goals for this study were to: (1) determine the effect of L. maackii presence on inorganic (ammonium, nitrate, total inorganic nitrogen), organic (dissolved organic carbon, dissolved organic nitrogen) and microbial (soil microbial biomass $\mathrm{C}$ and $\mathrm{N}$ ) pools 
across seasons; (2) explore how the dynamics of these pools might change with time since shrub removal; and (3) determine which environmental variables might explain inorganic and organic nutrient pools during different seasons. I predicted that nutrient pools would differ between plots where shrubs were present and where they had been removed, but did not posit directionality or magnitude because of the potential for competing processes to influence the nutrient dynamics. Belowground decay of honeysuckle roots, the loss of honeysuckle root exudates, and compensatory responses from canopy trees and recolonizing herbaceous species may increase, decrease, or mask differences between shrub present and shrub removal plots depending on their magnitude and importance at different times throughout the year. I also predicted that time since honeysuckle removal would be an important factor in determining the size of various nutrient pools. Honeysuckle removal plots that had been immediately cut before the experiment began were expected to have higher inorganic and organic nutrient pools than those that had been cut one or two years prior. This prediction was based on the expectation of nutrient flushing associated with root death, the lack of significant plant colonization in recently cut plots, and the lack of an early season drawdown in areas where honeysuckle shrubs were recently removed.

\section{Methods}

\section{Study area}

Fourteen study sites were located within two urban parks in Louisville, KY, USA. Cherokee Park ( $38^{\circ} 1^{\prime} 28.32^{\prime \prime}$ N, $\left.85^{\circ} 41^{\prime} 48.84^{\prime \prime} \mathrm{W}\right)$, a 166 ha park characterized by an extensive history of natural and anthropogenic disturbance (Carreiro and Zipperer 2011). 
Much of the tree canopy was destroyed by an F4 tornado in 1974 (Share 1976) and the woodland canopy consists of a mixture of naturally regenerated and planted trees. White ash (Fraxinus americana) was the most common dominant or co-dominant species in my sites, though common hackberry (Celtis occidentalis), sugar maple (Acer saccharum), and tulip poplar (Liriodendron tulipifera) were common secondary species. Joe Creason Park $\left(38^{\circ} 12^{\prime} 35.32^{\prime \prime} \mathrm{N}, 85^{\circ} 42^{\prime} 36.84^{\prime \prime} \mathrm{W}\right)$, a 25 ha park located in the Poplar Level neighborhood of Louisville, KY, which also suffered extensive damage from the same F4 tornado. Joe Creason Park had an extensive agricultural history before it naturally converted to woodlands during the first half of the 20th century. Green ash (Fraxinus pennsylvanica) was the dominant canopy species at the Joe Creason site, with common hackberry (Celtis occidentalis) and sugar maple (Acer saccharum) present as secondary species. Soils at these sites were characterized as being either well-drained, moderately deep Hapludalfs in the Caneyville series or very deep Paleudalfs in the Crider series. Slopes ranged from moderately steep to steep (9-26 degrees). In the upper $10 \mathrm{~cm}$ soil horizon, $\mathrm{pH}$ ranged from 5.33 to 7.8 among plots, organic matter content (carbonate-free) ranged from $4.25 \%$ to $10.6 \%$, and the $\mathrm{C}: \mathrm{N}$ molar ratio ranged between 10.6 and 15.2 (Carreiro, unpublished). The mean annual temperature in Louisville is $13.8^{\circ} \mathrm{C}$ and the region is characterized by warm, humid summers (mean July temperatures of $25.8^{\circ} \mathrm{C}$ ) and cool winters (mean January temperatures of $0.5^{\circ} \mathrm{C}$ ) (NCDC 2012). Mean annual precipitation is $113 \mathrm{~cm}$ and is evenly distributed throughout the year (Klebler 2000).

This experiment utilized a paired plot design in which one randomly selected plot at each site had all aboveground honeysuckle shrub biomass removed. This allowed me to compare the effects of honeysuckle presence vs honeysuckle removal. Because I was 
also interested in the effects of time since honeysuckle shrub removal, removal of honeysuckle shrubs was staggered to create a three-year removal chronosequenc (Table 4.1). One set of sites had honeysuckle shrubs removed between December 2008 and January 2009 (hereafter "year 2 removals"; $n=5$ sites). Honeysuckle shrub removals in a second set of sites was conducted between November 2009 and March 2010 (hereafter "year 1 removals"; $\mathrm{n}=5$ sites). The last set of honeysuckle removals occurred in February 2011 (hereafter "year 0 removals"; n=4 sites). During each removal period, freshly cut stumps were painted with $26 \%$ glyphosate isopropylamine salt solution (Roundup; Monsanto Company, St. Louis, MO, USA) to ensure shrub death. No additional shrub removals or herbicide treatments were applied after the initial removal to avoid confounding effects on microbial biomass measurements. L. maackii was the dominant exotic shrub in each site, though other exotic shrubs such as common buckthorn (Rhamnus cathartica) and Chinese privet (Ligustrum sinense) were present in small amounts at some sites. These shrubs, when present, were not removed.

Selection of available research sites in Cherokee Park was limited due to the parkwide eradication of invasive honeysuckle shrubs by the Louisville Olmsted Parks Conservancy. As a result, my study was forced to use pre-existing plots of different dimensions and an addition site in Joe Creason Park in order to have an adequate number of sites for the removal chronosequence. At eleven of the fourteen sites, two $10 \times 10 \mathrm{~m}$ plots were delineated with a minimum five $\mathrm{m}$ buffer zone separating and surrounding each plot. No shrubs were removed from the surrounding buffer zone during the honeysuckle shrub removal process. The three remaining sites (including the site at Joe Creason) had been previously established for a different honeysuckle study and were 
selected for inclusion to give me a sufficient number of year 0 removals $(n=3)$. At these sites, two 5x20 m plots were delineated with the longer dimension running downslope. Similar to the $10 \times 10 \mathrm{~m}$ plots, each of the $5 \times 20 \mathrm{~m}$ plots were surrounded and separated by a minimum five $\mathrm{m}$ buffer zone and no shrubs were removed from the buffer zone during the honeysuckle shrub removal process. A summary of the removal chronosequence and sites used can be found in Table 4.1.

\section{Soil sampling}

Soil samples were collected in February, April, May, August, October, and November of 2011 and February and April of 2012. Because the shapes of the plots differed, slightly different sampling procedures were used to obtain soil samples. Each 10x10 m plot was subdivided into sixteen $2.5 \times 2.5 \mathrm{~m}$ quadrats. The four innermost quadrats were sampled at each collection date using a $2 \mathrm{~cm}$ diameter soil corer. Only the four innermost quadrats were sampled in an attempt to minimize litter and root inputs from honeysuckle shrubs in the surrounding shrub buffer zone. Within each quadrat, five $10 \mathrm{~cm}$ deep soil samples were collected at random and pooled together. In the $5 \times 20 \mathrm{~m}$ plots, each run was divided into four $5 \times 5 \mathrm{~m}$ downhill segments. Each segment was further divided to create a center running the length of the plot that was at least $1 \mathrm{~m}$ away from the shrub buffer zone on each side. Five $10 \mathrm{~cm}$ deep samples were collected from this center quadrat at random and pooled together. The four pooled samples from both plot types were analyzed for nutrients or microbial biomass and used to calculate the mean concentrations for each plot at each date. Samples were placed in plastic zip lock bags and transported to the lab on ice and refrigerated. Within 36 hours of collection, 
soils were mixed by hand and all visible plant, rock, and other debris materials were removed. Soil extractions and fumigations were performed immediately after mixing and solutions frozen at $-20^{\circ} \mathrm{C}$ for analysis at the University of Toledo. At each date, an identical number of soil cores were also collected to determine soil moisture content. These cores were collected using the same sampling methodology used to obtain the nutrient and microbial biomass cores. After being transported to the lab on ice, soil moisture was determined gravimetrically by oven drying $5.00 \mathrm{~g}$ of wet soil (range: 5.00 to $5.05 \mathrm{~g}$ ) for 24 hours at $105^{\circ} \mathrm{C}$. After drying, samples were reweighed and soil moisture content was calculated on a $\mathrm{g}$ water per $\mathrm{g}$ dry soil basis.

\section{Nutrients and microbial biomass}

Soils were extracted and fumigated according to the procedures outlined in Weintraub et al. (2007) and Scott-Denton et al. (2006). To estimate ammonium $\left(\mathrm{NH}_{4}{ }^{+}\right)$, nitrate $\left(\mathrm{NO}_{3}{ }^{-}\right)$, dissolved inorganic nitrogen (DIN), dissolved organic carbon (DOC), and dissolved organic nitrogen (DON) in the soil, $25 \mathrm{ml}$ of a $0.5 \mathrm{M}$ potassium sulfate $\left(\mathrm{K}_{2} \mathrm{SO}_{4}\right)$ solution was used for extracting approximately $5 \mathrm{~g}$ (range: 5.00 to $5.05 \mathrm{~g}$ ) of each soil sample. An orbital shaker table was used to agitate samples at $120 \mathrm{rpm}$ for $1 \mathrm{~h}$. Immediately following agitation, samples were vacuum-filtered through Pall A/E glass fiber filters into $50 \mathrm{ml}$ centrifuge tubes (Falcon $50 \mathrm{ml}$ centrifuge tube, Corning Life Sciences, Corning, NY) and frozen at $-20^{\circ} \mathrm{C}$ until analysis. For estimating cytoplasmic microbial biomass $\mathrm{C}$ and $\mathrm{N}$ (hereafter referred to as 'MB-C' and 'MB-N'), additional soil subsamples were fumigated with chloroform (99.9\% chloroform with approximately 50 ppm amylene as preservative; Fisher Chemical; Pittsburgh, PA) to disrupt microbial cells. 
Approximately $5 \mathrm{~g}$ (range: 5.00 to $5.05 \mathrm{~g}$ ) of mixed soil was placed in a $250 \mathrm{ml}$ Erlenmeyer flask. Two $\mathrm{ml}$ of chloroform were added directly to the soil in each flask, which was stoppered immediately with a rubber stopper and allowed to incubate for 24 hours under a fume hood. After 24 hours, flasks were unstoppered and allowed to vent under a fume hood for 30 minutes. Samples were then extracted with $25 \mathrm{ml}$ of a $0.5 \mathrm{M}$ $\mathrm{K}_{2} \mathrm{SO}_{4}$ solution using the procedure described above. MB-C and MB-N were then quantified by taking the difference in DOC and DON between fumigated and unfumigated samples (Brookes et al. 1985). Because extraction efficiency is unknown for the soils at these sites, no correction factor (kEC) was applied.

Unfumigated samples were analyzed for $\mathrm{NH}_{4}{ }^{+}$and $\mathrm{NO}_{3}{ }^{-}$using colorimetric microplate assays. A modified Berthelot reaction was used to measure concentrations of $\mathrm{NH}_{4}{ }^{+}$(Rhine et al. 1998). To analyze $\mathrm{NO}_{3}{ }^{-}$, nitrate was reduced to nitrite followed by colorimetric determination using a modified Griess reaction (Doane and Horwath 2003). A Bio-Tek Synergy HT microplate reader (Bio-Tek Inc., Winooski, VT) was used to determine absorbance values for $\mathrm{NH}_{4}{ }^{+}$and $\mathrm{NO}_{3}{ }^{-}$. DOC and DON were analyzed using a Shimadzu TOC-VCPN analyzer (Shimadzu Scientific Instruments Inc., Columbia, MD, USA). Blank samples containing only $\mathrm{K}_{2} \mathrm{SO}_{4}$ were used to correct all concentrations.

\section{Environmental and vegetation measurements}

Honeysuckle shrub stem density, honeysuckle basal area, and tree basal area data were collected at each plot in August of 2011. Diameter-at-breast-height (dbh) was used to calculate tree basal area $\left(\mathrm{BA}=\pi \mathrm{r}^{2}\right)$ within each plot. For honeysuckle, only shrubs that were $\geq 1 \mathrm{~m}$ in height were included as these shrubs are large enough to provide shading 
and substantial litter input. Stem density was measured by totaling the number of live basal stems from each shrub within a plot. Data on shrub basal area was obtained by averaging two diameters at the root collar approximately $1 \mathrm{~cm}$ above soil level. This method was used because the base of honeysuckle shrubs is often irregularly shaped. Values for stem density and basal area were then converted to $\mathrm{a} \mathrm{ha}^{-1}$ basis to allow for standardized comparisons with other studies. In addition, \% bare soil and \% herb cover within each of the sampled quadrats were estimated at each collection date. Percent bare soil in each sampled quadrat was estimated visually as the percentage of each quadrat that was not covered by leaf litter or twigs. Percent herb cover was quantified by visually estimating the percentage of each quadrat that was covered by herbaceous canopy. In cases where many herbaceous plants overlapped, it was possible to estimate herb covers greater than $100 \%$ while still having open ground.

\section{Data Analysis}

Nutrient and microbial biomass data were analyzed using mixed model repeatedmeasures (rm)-ANOVAs (PROC MIXED; SAS software 9.3, SAS Institute, Inc., Cary, NC). Two sets of models were used to analyze the data from this study. The first set of models was used to analyze the effect of honeysuckle shrubs on nutrient and microbial biomass pools and all plots were used in this analysis. It included honeysuckle shrub presence/removal, sampling date, and a honeysuckle $\mathrm{x}$ date interaction as fixed effects. Site $(n=14)$ was treated as a random effect and sampling date served as the repeated factor. Post hoc comparisons were made using the Tukey HSD test to examine differences between honeysuckle present and removed plots within each date. The second 
set of models was used to analyze the effects of time since honeysuckle shrub removal (hereafter referred to as "chronosequence") on nutrient and microbial biomass pools. In order to focus on the effects of chronosequence, only honeysuckle shrub removal plots were used in this analysis. Chronosequence, sampling date, and a chronosequence $\mathrm{x}$ date interaction were modeled as fixed effects. Site $(n=14)$ was treated as a random effect and sampling date served as the repeated factor. Post hoc comparisons using the Tukey HSD test were made to examine differences between chronosequence removals within each date. Residuals from both models were tested for normality and equality of variance (PROC UNIVARIATE; SAS software 9.3) and $\log _{10}(\mathrm{x})$ transformations were applied as necessary to satisfy the assumptions of normality. Akaike information criterion (AIC) values were used to determine the best-fit covariance structure for errors (Wang and Goonewardene 2004). As these analyses featured both REPEATED and RANDOM statements, the Kenward-Roger correction for denominator degrees of freedom (ddfm=KR) was used (Kenward and Roger 1997).

Individual sampling dates were pooled into season groupings when possible to increase the sample size for regression analysis (Table 4.2). Best-subset multiple regression analysis was then used to determine the best linear regression model for the nutrient and microbial biomass pools during each season grouping. All plots (i.e. honeysuckle present and removed) were used in the regression analysis. Correlations between inorganic $\mathrm{N}$ pools, DON, DOC, MB-C, and MB-N were analyzed using PROC CORR (SAS software 9.3) to identify strong bivariate correlations (Pearson's r>0.70; Appendix 3). Multicollinearity among pairs of predictor variables was also checked by using PROC CORR (SAS software 9.3). Honeysuckle stem density and honeysuckle 
basal area were found to be highly correlated (Pearson's r=0.99; Appendix 4), so honeysuckle basal area was dropped from the models. PROC REG (SAS software 9.3) was used to test predictors against each other and calculate variance inflation factors (VIF). VIFs that were $\leq 2.5$ indicated a lack of significant multicollinearity.

Models of nutrient and microbial biomass for each season grouping included the following variables as possible predictors: honeysuckle stem density, tree basal area, \% herb cover, \% bare soil, plot aspect, and soil moisture content. Percent bare soil was transformed by the arcsine of the square-root transformation to improve the fit of residuals to the normal distribution. The arcsine of the square-root transformation was not applicable to the $\%$ herb cover variable because the sampling method allowed cover estimates to exceed $100 \%$. Aspect is a circular variable and was transformed using trigonometric functions (Roberts 1986). The cosine and sine of the aspect were used to generate two new variables, northness and eastness, respectively. The SELECTION= ADJRSQ (adjusted r-square) option in PROC REG was used to select the 10 best subsets of independent variables to model each nutrient pool within each season (Freund and Littell 2000). The model with the smallest AIC was then selected as the best overall model (Akaike 1973). Because models with AIC differences of less than 2 are considered to be indistinguishable (Burnham and Anderson 2002), the Bayesian Information Criterion (BIC; Schwarz 1978) was used as a tie-breaker with the smallest BIC representing the best overall model. In cases where the BIC was unable to break the tie, the model with the fewest predictor variables was selected as the best overall model. After selecting the best overall regression model, the DFFITS option was used to identify influential data points. DFFITS values greater than 1.0 were considered to be influential 
(Neter et al. 1990) and were further examined. In cases where there was strong evidence of experimental error (i.e. the value of one quadrant in a plot was at least three times higher than the values of the remaining three quadrants), the erroneous data point was noted and omitted from the reported results. In cases where evidence of error was absent or questionable, models with and without the influential data point(s) were run and report the results of both models. Finally, each model was assessed for statistical significance $(p<0.05)$. To avoid the problem of finding significant differences due to multiple model runs, the false discovery rate method (Benjamini and Hochberg 1995) was used (PROC MULTTEST; SAS software 9.3).

\section{$\underline{\text { Results }}$}

The values observed for microbial biomass $\mathrm{C}$ (MB-C range: $314-618 \mu \mathrm{g} \mathrm{C} \mathrm{g}^{-1}$ soil) in my study are within the ranges reported by Vance et al. (1987; 102-2073 $\mu \mathrm{g} \mathrm{C} \mathrm{g}^{-1}$ soil) and Henrot and Robertson (1994; 61-2000 $\mathrm{g} \mathrm{C} \mathrm{g} \mathrm{g}^{-1}$ soil) for temperate forest soils. The values obtained for microbial biomass $\mathrm{N}$ in my study (MB-N range: $36-127 \mu \mathrm{g} \mathrm{N} \mathrm{g}^{-1}$ soil) also fell mostly within the ranges reported by Sharma et al. (2004; 96-142 $\mu \mathrm{g} \mathrm{N} \mathrm{g}^{-1}$ soil) and Díaz-Ravina et al. (1988; 132-240 $\mu \mathrm{g} \mathrm{N} \mathrm{g}^{-1}$ soil) for temperate and broadleaf, deciduous forests. Overall, our MB-C and MB-N values are similar to values reported for temperate beech forests in Germany (Zong and Makeschin 2006), sugar maple forests in the Catskill Mountains of New York (Templer et al. 2003), oak forests in northwestern Spain (Díaz-Raviña et al. 1995), and mixed-oak forests in northeast India (Devi and Yadava 2006). 


\section{Honeysuckle presence and removal chronosequence}

Unless otherwise noted, the exclusion of the Joe Creason site did not change the overall results of the models and all results presented below include the Joe Creason site in the analyses. Table 4.3 summarizes the results from the two sets of rm-ANOVA models (see Appendix 5-7 for means and post hoc comparison). As expected, the main effect of sampling date was significant for all inorganic, organic, and microbial biomass pools in the honeysuckle shrub presence/removal model. Counter to expectations, the main effect of honeysuckle presence was only significant for microbial biomass N (MB$\mathrm{N} ; p=0.017)$. While mean MB-N was higher in shrub present plots compared to shrub removal plots across all dates except October 2011, post hoc analysis found no statistically significant differences $(p \leq 0.05)$ or strong trends $(0.05 \leq p \leq 0.10)$ between shrub present and removed plots at any date (Fig 4.1). It should be noted that the significance of honeysuckle presence was only observed when the Joe Creason site was included in the analysis. When the Joe Creason site was removed, the effect of honeysuckle shrubs became non-significant $\left(F_{1,156}=1.12 ; p=0.29\right)$. The shrub x date interaction was not significant for any nutrient pool.

Similarly, sampling date differed significantly for all nutrient and microbial pools in the chronosequence removal model (Table 4.3). While the main effect of chronosequence was not significant for any single nutrient pool, the chronosequence $\mathrm{x}$ sampling date interaction did differ significantly for both MB-C $(p=0.029)$ and MB-N $(p<0.0001)$. For both MB-C and MB-N, April 2011 was the only date to display significant differences between the chronosequence groupings (Fig 4.2). During this month, MB-C was higher in year 1 removals compared to year $0(p<0.0007)$ or year 2 
$(p<0.002)$ removals, but no differences were observed between year 0 and year 2 removals $(p<0.48)$. The pattern for MB-N was the same, with year 1 removals having significantly more MB-N compared to year $0(p<0.0001)$ or year $2(p<0.0001)$ removals in April 2011. No significant differences were observed for any of the inorganic nitrogen pools.

Across all plots and sampling dates in this study, $\mathrm{NO}_{3}{ }^{-}$comprised the bulk of the DIN nutrient pool. Mean $\mathrm{NO}_{3}{ }^{-}$as a percentage of mean DIN ranged from a low of $67.3 \%$ in April 2012 to a high of $92.4 \%$ in August 2011. Unsurprisingly, $\mathrm{NO}_{3}{ }^{-}$was highly

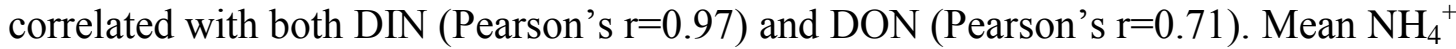
was a smaller percentage of mean DIN, ranging from a low of 7.5\% in August 2011 to a high of $32.7 \%$ in April 2012. $\mathrm{NH}_{4}{ }^{+}$tended to account for a larger percentage of DIN in February (15.5\% in $2011 ; 20.7 \%$ in 2012$)$ and April (26.5\% in $2011 ; 32.7 \%$ in 2012$)$ compared to the other sampling months in the study ( $7.5 \%$ to $13.8 \%$ of DIN). DOC ranged from a low of $62 \pm 2.4 \mu \mathrm{g}_{\mathrm{DOC} \mathrm{g}}{ }^{-1}$ soil in February 2011 to a high of $297 \pm 28.1 \mu \mathrm{g}$ DOC $\mathrm{g}^{-1}$ soil in November 2011. The DON nutrient pool was smaller and displayed slightly different dynamics. DON was lowest in February $2011\left(6 \pm 0.4 \mu \mathrm{g} \mathrm{DON} \mathrm{g}^{-1}\right.$ soil); however, peak DON pools different between shrub present and removed plots. DON was highest in October 2011 for shrub present plots $\left(29 \pm 5 \mu \mathrm{g}^{\mathrm{DON} \mathrm{g}}{ }^{-1}\right.$ soil) and May 2011 for shrub removal plots $\left(30 \pm 9.3 \mu \mathrm{g}\right.$ DON g ${ }^{-1}$ soil). DIN and DON were strongly correlated (Pearson's r=0.73). MB-C was lowest in October $2011\left(314 \pm 19.2 \mu \mathrm{g} \mathrm{C} \mathrm{g}^{-1}\right.$ soil) and highest in November $\left(618 \pm 47.2 \mu \mathrm{g} \mathrm{C} \mathrm{g}^{-1}\right.$ soil). The MB-N pool was smaller in size than the MB-C pool, ranging from a low of $36 \pm 2.6 \mu \mathrm{g} \mathrm{N} \mathrm{g}^{-1}$ soil in October 2011 to a high of $127 \pm 11.2 \mu \mathrm{g} \mathrm{N} \mathrm{g}^{-1}$ soil in August 2011. The MB-N pool was $11.7 \%$ to $27.8 \%$ the size of 
the MB-C depending on the date and MB-C and MB-N showed a fairly high degree of correlation as well (Pearson's r=0.69). MB-N was 1.6 to 8.7 times larger than the DIN nutrient pool for all dates except in October 2011. In that month, the DIN pool was 0.8 times larger than the MB-N pool. MB-N was 1.4 to 11.8 times larger than the DON pool depending on the date.

\section{Environmental variables}

Best subset regression analyses were used to examine the relative explanatory strength of vegetative and site factors on various nutrient pools during each season grouping. Models that were found to be statistically significant according to the false discovery method are summarized in Table 4.4 (see Appendix 8 for all models). In spring 2011, the gravimetric soil moisture had significant positive regression weight in the models for $\mathrm{NH}_{4}{ }^{+}, \mathrm{NO}_{3}{ }^{-}, \mathrm{DIN}$, and DON, indicating that these nutrient pools were higher in areas with higher soil moisture. Pools of DOC, MB-C, and MB-N were larger in areas with higher levels of bare soil as indicated by the significant positive regression weight of the arcsine transformed $\%$ bare soil. Tree basal area was a significant positive regressor for $\mathrm{NO}_{3}{ }^{-}$, DIN, and DOC while herb cover was a positive regressor for $\mathrm{NO}_{3}{ }^{-}$and DIN. Influential data points (DFFITS $>1$ ) were retained in the spring models given in Table 4.7 as I found no justifications to drop them from the models. The models for $\mathrm{NO}_{3}{ }^{-}$and DIN were influenced by two plots (4-R and $20-\mathrm{R})$. When these data points were removed, the adjusted- $\mathrm{R}^{2}$ remained the same for both models. The same two plots were found to be influential in the models for DOC (plot 4-R) and DON (plot 20-R). Removal of the influential data point from the DOC model did not change the adjusted- $\mathrm{R}^{2}$. Conversely, 
removal of plot 20-R from the DON model caused tree basal area to drop from the model and the adjusted- $\mathrm{R}^{2}$ value to rise from 0.15 to 0.22 . The MB-C model was influenced by a single plot (22-C). When this influence point was dropped from the model, the adjusted- $\mathrm{R}^{2}$ value increased from 0.19 to 0.22 . Similarly, MB-N was influenced by a single plot (7-C). The removal of this data point increased the adjusted- $\mathrm{R}^{2}$ value to 0.26 and also led to the inclusion of the herb cover variable into the model (no significant regressor weight).

The variables used in the models were generally poor predictors of nutrient pools during the summer 2011 season and only models for MB-C and MB-N were found to be significant during this season. Unsurprisingly, gravimetric soil moisture had a significant positive regression weight in both models, indicating that higher soil moisture content was associated with higher levels of MB-C and MB-N. The arcsine transformed \% bare soil variable was also significant in the MB-C model and had a positive regression weight. Influential data points (DFFITS >1) were retained in both models presented in Table 4.7. A single plot (7-C) was influential in both models. When removed from the MB-C model, the adjusted- $\mathrm{R}^{2}$ value fell from 0.35 to 0.22 and the model became insignificant according to the false discovery method. No changes were observed in adjusted- $\mathrm{R}^{2}$ when the influential data point was removed from the MB-N model.

Significant models were found for DOC, MB-C, and MB-N during fall 2011; however, no common pattern was observed between the models. Soil moisture content was a significant positive regressor for $\mathrm{DOB}$ and $\mathrm{MB}-\mathrm{N}$, indicating that higher moisture content was associated with increases in these pools. Eastness was a significant positive regressor in the model for DOC, indicating that east facing plots had higher dissolved 
organic carbon concentrations. Conversely, the arcsine transformed \% bare soil variable was a significant negative regressor in the model of MB-C. As this season covers litter fall inputs from trees, it is unsurprising that higher concentrations of $\mathrm{MB}-\mathrm{C}$ were associated with areas with more leaf litter and reduced bare soil. Influential data points (DFFITS >1) were retained in the DOC model. A single data point (7-C) was found to influence the model of DOC for fall 2011; however, removal of this data point lowered the adjusted- $\mathrm{R}^{2}$ value from 0.24 to 0.14 and the model became insignificant according to the false discovery method. No influential data points were observed in either of the microbial biomass models.

During the winter of 2011, models were able to explaining a significant amount of the variance for $\mathrm{NO}_{3}{ }^{-}$, DIN, DOC, MB-C, and MB-N. Areas with higher soil moisture content also had higher $\mathrm{NO}_{3}{ }^{-}$, DIN, MB-C, and MB-N as indicated by soil moisture's significant positive regression weight in the models. The significant positive regressor weight for the arcsine transformed \% bare soil indicated that DOC and MB-N were higher in areas with more bare soil. No influential data points were observed in the models for $\mathrm{NO}_{3}{ }^{-}$, DIN, MB-C, or MB-N. A single plot (21-C) was found to be influential to the model of DOC. When this data point was omitted, the adjusted- $\mathrm{R}^{2}$ value decreased from 0.18 to 0.16 and the model became insignificant according to the false discovery method.

In spring 2012, models of DOC, DON, MB-C, and MB-N were significant. The arcsine transformed \% bare soil had a significant positive regressor weight in all of the models, indicating that more bare soil was associated with higher levels of DOC, DON, MB-C, and MB-N. The models for MB-C and MB-N had a significant positive regressor 
weight for honeysuckle stem density, while tree basal area and herb cover were also positive regressors in the MB-N model. Lastly, higher soil moisture content was associated with higher levels of DOC in the spring of 2012. No influential data points were observed in the models for DON; however, all other significant models for spring 2012 were found to have influential data points (DFFITS >1). Two plots (12-C and 21-C) influenced the model for DOC. When these data points were omitted, the adjusted- $\mathrm{R}^{2}$ value rose from 0.25 to 0.35 . The model for MB-C was also influenced by two plots (4-R and 12-C). Removal of these plots from the data analysis increased the adjusted- $\mathrm{R}^{2}$ value rose from 0.33 to 0.45 and reduced the model to include only two significant, positive regressors (honeysuckle stem density and the arcsine transformed \% bare soil). The model for MB-N was influenced by three plots (12-C, 14-C, and 21-C). Removal of these data points did not affect the adjusted- $\mathrm{R}^{2}$ value nor did it change the significance of the regressors in the model.

\section{$\underline{\text { Discussion }}$}

\section{Effect of honeysuckle shrubs and time since removal}

Because the leaf litter from honeysuckle shrubs has a significantly different chemistry compared to native tree litters (Arthur et al 2012; Poulette and Arthur 2012; Trammell et al. 2012), I predicted nutrient pools and soil microbial biomass to differ between areas where honeysuckle was present versus areas where it had been removed. Contrary to my expectations, the data from this experiment suggests that honeysuckle shrubs may not affect soil nutrient and/or microbial biomass pools in urban woodland soils. Microbial biomass N (MB-N) was the only pool to display a significant 
honeysuckle shrub effect; however, this result depended entirely on the inclusion of an anomalous site (Joe Creason). Because the effect of honeysuckle shrubs on MB-N was not significant when the anomalous site was removed, I conclude that invasive shrub honeysuckle did not influence the MB-N pool and that the observed result was due to the inclusion of an anomalous site. No statistically significant differences were observed between honeysuckle shrub present and removed plots at any sampling date for any nutrient or microbial biomass pool. My predictions for the effect of time since honeysuckle removal were also partially rejected. Inorganic or organic nutrient pools did not differ significantly between the three year chronosequence removals, indicating that the effect of time since honeysuckle removal was not significant for those pools. Differences in MB-N and MB-C were observed between the chronosequence removals, but only at the beginning of the experiment (April 2011). After that, the chronosequence removals displayed no statistically significant differences in terms of MB-N and MB-C. Unlike some other invasive plant species (Ehrenfeld 2003), the presence of invasive shrub honeysuckles does not appear to influence the size of soil nutrient or microbial biomass pools and their removal may only have a small effect on microbial pools. There are at least three possible explanations for these results. First, invasive plants species can alter the abiotic and biotic properties of soils in ways that benefit themselves (Klironomos 2002; Callaway et al. 2004; Levine et al. 2006; Bever et al. 2010) while also harming native species (Reinhart et al 2003; Reinhart and Callaway 2006; Stinson et al. 2006; Jordan et al. 2008; Rodríguez-Echeverría et al. 2013). These changes may persist for years after invasive species removal, creating soil legacies that may inhibit native species re-establishment and alter nutrient cycling via changes in the 
microbial communities (Levine et al. 2006; Reinhart and Calloway 2006). While no studies have been conducted on the soil legacy effects of invasive honeysuckle shrubs, such legacies could explain the lack of a honeysuckle shrub or time since removal effect in this study. Invasive honeysuckle shrubs were among the species planted by the Olmsted firm during the creation of Cherokee Park in early 1890s (Carreiro and Zipperer 2011) and some of the sites in this study contain honeysuckle shrubs that are more than 30 years old (Carreiro, unpublished data). If soil legacy effects are present following the removal of long-standing honeysuckle shrub thickets, then our three year removal chronosequence may not have allowed sufficient time for these legacies to dissipate and for the soil and soil communities to recover.

Alternatively, the lack of a shrub and chronosequence effect may have been due to compensation by the plant community following removal of honeysuckle shrubs. Removal of dense honeysuckle thickets allows recolonization by early succession species (Luken et al. 1997a). Furthermore, total foliar biomass has been reported to be up to 1.5 times lower in forests invaded by L. maackii compared to non-invaded forests of equivalent tree basal area (Trammell et al. (2012). Removal of early season nitrogen competitors like shrub honeysuckles may have allowed herbaceous and tree species to take advantage of available inorganic soil nitrogen pools instead, potentially negating the loss of shrub biomass in the removal plots. While a rm-ANOVA did not find an overall difference between chronosequence removals for mean herb cover (Appendix 9), there was a clear trend of year 1 and year 2 removals having higher mean herb cover compared to year 0 removals at most sampling dates (Appendix 10). Compensatory responses from recolonizing herbaceous species may have also influenced organic nutrient and microbial 
biomass pools. Organic and microbial biomass pools can be influenced by both the quality and quantity of litter inputs and root exudates (Fisk and Fahey 2001; Kara et al. 2008), and previous studies in successional fields have reported that early successional species produce high quality litter that tends to decompose more rapidly than litter produced by later successional species (Kazakou et al. 2006; Kazakou et al. 2009). Thus, it is possible that the loss of high quality honeysuckle litter may be offset by the combination of high quality early succession herbaceous litter and nutrient inputs from decaying honeysuckle roots.

Lastly, the effect of shrubs between plots may have been smaller than the effect of variation between sites. It should be noted that while invasive plant species have been generally observed to increase decomposition, $\mathrm{N}$ cycling, and microbial biomass, not all invasives have demonstrated this pattern. Ehrenfeld (2003) reported that invasive species showed no clear patterns of increase or decrease in microbial biomass $\mathrm{C}$ (six studies total). Furthermore, the impacts of invasive species on extractable inorganic nitrogen pools $\left(\mathrm{NH}_{4}\right.$ and $\left.\mathrm{NO}_{3}\right)$ varied widely and invasive species were found to increase (9 of 17), decrease (4 of 17), or have no effect (4 of 17 cases) on these nutrient pools. Liao et al. (2008) noted that while nutrient pools generally increased in response to plant invasion, responses to invasive demonstrated a high degree of variability. Furthermore, soil microbial biomass can be influenced by a number of factors including soil moisture and temperature (Wardle 1992; Taylor et al. 1999), soil pH (Wardle 1992), soil texture and type (Bauhus et al. 1998; Díaz-Raviña et al. 1995), soil organic matter quality (Zak et al. 1990a; Sparling 1992), and differences in the species forming the forest canopy (Templer et al. 2003). Because the sites used in this study differed in terms of the canopy 
and herbaceous species present, it is possible that microbes experienced large differences in SOM inputs and other environmental conditions between sites. If the effects of $L$. maackii on soil nitrogen and carbon pools are small, transitory, and/or less important than other environmental and vegetative factors, then such variation could explain my inability to detect an overall effect of shrubs in my models.

\section{Importance of environmental variables}

Soil moisture content has long been known to influence microbial biomass dynamics (Wardle 1992; Taylor et al. 1999), so it is unsurprising that it was an important predictor in most of my models. Percent bare soil also had a significant, positive regression weigh in many of the models. This was contrary to my expectations as I expected areas with more bare soil (i.e. less leaf litter present) to have small nutrient pools. One possible explanation is that percent bare soil is serving as a proxy for some other variable, most likely exotic earthworm activity, which occurs throughout the year at these sites (Chapter 2). Exotic earthworm species are known to actively reduce forest leaf litter layers (Suárez et al. 2006) and differences in the size and composition (i.e. litter feeding or geophagus species) of earthworm communities could lead to differences in the amount of bare soils between sites. A correlation analysis using March 2012 earthworm data from Chapter 1 (see Appendix 11) did not reveal any strong correlations between mean total worm biomass and any nutrient pools. It should be noted; however, that this analysis was small $(n=20)$ and included some sites that were close $(<10 \mathrm{~m})$ to sites where earthworm biomass was sampled but which were not directly sampled themselves. 


\section{Invasional Meltdown}

In Chapter 2 and 3, I suggested the potential for an invasional meltdown between invasive honeysuckle shrubs and exotic earthworms. Briefly, my proposed model suggested that honeysuckle shrubs would lead to increases in exotic earthworm populations due to high quality litter inputs in the winter and more favorable microclimate conditions during the summer. In turn, exotic earthworms would facilitate honeysuckle shrubs by creating bare soil conditions that favor honeysuckle seedling establishment and creating an early season nutrient pulse. Though I did not observe a statistical difference between honeysuckle present and removed plots, concentrations of soil $\mathrm{NH}_{4}{ }^{+}$were high in April 2011, February 2012, and April 2012. As ammonium is one of the major nitrogenous excretions on Eurasian earthworms (Needham 1957), this result provides some tangential evidence for the proposed early season nitrogen pulse.

\section{$\underline{\text { Conclusions }}$}

This study examined the effects of honeysuckle shrub removal on nutrient and microbial biomass pools in urban woodlands. While these pools were found to vary temporally, honeysuckle presence and time since honeysuckle shrub removal were not important in explaining nutrient dynamics at each sampling date. Instead, soil moisture content and percent bare soil were the most common, positive predictors within each season. It is unclear from these results whether honeysuckle shrubs have only minor impacts on nutrient and microbial biomass pools or whether soil legacy effects from honeysuckle presence. While honeysuckle removal may not lead to altered nutrient dynamics in urban woodland systems over the short term (i.e. two years post removal), 
managers involved in honeysuckle removal projects should be aware of the potential for soil legacy effects. 
Table 4.1. Study site locations for soil nutrient study. Sites 3 through 17 featured two 10x 10 meter plots. Sites 20 through 22 featured two plots that were constructed as $5 \times 20$ meter long runs. All plots were separated and surrounded by a five meter buffer. $\mathrm{H}=$ honeysuckle shrubs present, $\mathrm{R}=$ honeysuckle shrubs removed. Shrub removal plots were categorized into three chronosequence categories depending on when the honeysuckle shrubs were removed. Year 0 sites were cut in Feb 2011. Year 1 sites were cut between Nov 2009 and Mar 2010. Year 2 plots site cut between Dec 2008 and Jan 2009. Honeysuckle stem density is expressed as stems per hectare while basal area is expressed as $\mathrm{m}^{2}$ per hectare.

\begin{tabular}{|c|c|c|c|c|c|c|c|c|}
\hline Site & $\begin{array}{l}\text { Coordinates } \\
\text { (dd) }\end{array}$ & Park & Chronosequence & $\begin{array}{l}\text { HS Stem Density } \\
\quad(\# / \text { ha) }\end{array}$ & $\begin{array}{c}\text { HS Basal Area } \\
\left(\mathrm{m}^{2} / \mathrm{ha}\right)\end{array}$ & $\begin{array}{c}\text { Tree Basal Area } \\
\left(\mathrm{m}^{2} / \mathrm{ha}\right)\end{array}$ & $\begin{array}{l}\text { Dominant Slope } \\
\quad \text { (degrees) }\end{array}$ & $\begin{array}{c}\text { Aspect } \\
\left(0^{\circ}=\mathrm{N}\right)\end{array}$ \\
\hline $3-\mathrm{H}$ & $38.245 ;-85.696$ & Cherokee & --- & 12500 & 6.10 & 8.89 & 11 & $\mathrm{~W}\left(271^{\circ}\right)$ \\
\hline $3-\mathrm{R}$ & $38.245 ;-85.696$ & Cherokee & Year 2 & 2500 & 0.08 & 24.82 & 12 & $\mathrm{~W}\left(271^{\circ}\right)$ \\
\hline $4-\mathrm{H}$ & $38.242 ;-85.696$ & Cherokee & --- & 12700 & 8.08 & 40.46 & 20 & $\operatorname{SE}\left(149^{\circ}\right)$ \\
\hline $4-\mathrm{R}$ & $38.242 ;-85.696$ & Cherokee & Year 2 & 200 & 0.00 & 20.80 & 18 & $\mathrm{~S}\left(158^{\circ}\right)$ \\
\hline $5-\mathrm{H}$ & $38.241 ;-85.696$ & Cherokee & --- & 7100 & 3.00 & 24.80 & 18 & $\mathrm{E}\left(105^{\circ}\right)$ \\
\hline $5-\mathrm{R}$ & $38.241 ;-85.696$ & Cherokee & Year 2 & 500 & 0.03 & 31.01 & 21 & $\mathrm{E}\left(101^{\circ}\right)$ \\
\hline 7-H & $38.241 ;-85.693$ & Cherokee & --- & 9200 & 5.00 & 34.54 & 16 & $S\left(162^{\circ}\right)$ \\
\hline 7-R & $38.241 ;-85.693$ & Cherokee & Year 1 & 800 & 0.05 & 0.69 & 17 & $\mathrm{~S}\left(162^{\circ}\right)$ \\
\hline $8-\mathrm{H}$ & $38.234 ;-85.684$ & Cherokee & --- & 17100 & 8.30 & 13.97 & 10 & $\mathrm{~W}\left(259^{\circ}\right)$ \\
\hline $8-\mathrm{R}$ & $38.234 ;-85.684$ & Cherokee & Year 2 & 300 & 0.15 & 28.09 & 11 & $\mathrm{~W}\left(253^{\circ}\right)$ \\
\hline $10-\mathrm{H}$ & $38.235 ;-85.668$ & Cherokee & --- & 8500 & 4.31 & 17.46 & 13 & $\operatorname{NE}\left(22^{\circ}\right)$ \\
\hline $10-\mathrm{R}$ & $38.235 ;-85.668$ & Cherokee & Year 2 & 600 & 0.03 & 7.73 & 15 & $\operatorname{NE}\left(37^{\circ}\right)$ \\
\hline
\end{tabular}


Table 4.1 cont.

\begin{tabular}{|c|c|c|c|c|c|c|c|c|}
\hline Site & $\begin{array}{l}\text { Coordinates } \\
\text { (dd) }\end{array}$ & Park & Chronosequence & $\begin{array}{l}\text { HS Stem Density } \\
\quad(\# / \text { ha) }\end{array}$ & $\begin{array}{l}\text { HS Basal Area } \\
\left(\mathrm{m}^{2} / \mathrm{ha}\right)\end{array}$ & $\begin{array}{c}\text { Tree Basal Area } \\
\left(\mathrm{m}^{2} / \mathrm{ha}\right)\end{array}$ & $\begin{array}{l}\text { Dominant Slope } \\
\quad \text { (degrees) }\end{array}$ & $\begin{array}{l}\text { Aspect } \\
\left(0^{\circ}=\mathrm{N}\right)\end{array}$ \\
\hline $11-\mathrm{H}$ & $38.242 ;-85.696$ & Cherokee & --- & 12500 & 6.50 & 11.58 & 20 & $\operatorname{SE}\left(149^{\circ}\right)$ \\
\hline $11-\mathrm{R}$ & $38.242 ;-85.696$ & Cherokee & Year 1 & 1200 & 0.07 & 15.89 & 17 & $\operatorname{SE}\left(148^{\circ}\right)$ \\
\hline $12-\mathrm{H}$ & $38.242 ;-85.696$ & Cherokee & --- & 20000 & 9.58 & 36.20 & 21 & $\operatorname{SE}\left(155^{\circ}\right)$ \\
\hline $12-\mathrm{R}$ & $38.242 ;-85.696$ & Cherokee & Year 1 & 300 & 0.01 & 24.65 & 19 & $\mathrm{~S}\left(158^{\circ}\right)$ \\
\hline $13-\mathrm{H}$ & $38.243 ;-85.700$ & Cherokee & --- & 9100 & 4.75 & 3.42 & 17 & $\mathrm{~S}\left(158^{\circ}\right)$ \\
\hline $13-\mathrm{R}$ & $38.243 ;-85.700$ & Cherokee & Year 1 & 400 & 0.02 & 24.11 & 17 & $\mathrm{~S}\left(161^{\circ}\right)$ \\
\hline $14-\mathrm{H}$ & $38.243 ;-85.700$ & Cherokee & --- & 8800 & 4.50 & 16.84 & 16 & $\operatorname{SE}\left(150^{\circ}\right)$ \\
\hline $14-\mathrm{R}$ & $38.243 ;-85.700$ & Cherokee & Year 1 & 600 & 0.03 & 7.54 & 17 & $\operatorname{SE}\left(152^{\circ}\right)$ \\
\hline $17-\mathrm{H}$ & $38.234 ;-85.684$ & Cherokee & --- & 17100 & 8.30 & 13.97 & 10 & $\mathrm{~W}\left(259^{\circ}\right)$ \\
\hline $17-\mathrm{R}$ & $38.234 ;-85.684$ & Cherokee & Year 0 & 500 & 0.01 & 29.23 & 10 & $\mathrm{~W}\left(253^{\circ}\right)$ \\
\hline $20-\mathrm{H}^{*}$ & $38.238 ;-85.689$ & Cherokee & --- & 19600 & 9.65 & 7.64 & 26 & $\mathrm{~S}\left(172^{\circ}\right)$ \\
\hline $20-\mathrm{R}^{*}$ & $38.238 ;-85.689$ & Cherokee & Year 0 & 0 & 0.00 & 46.34 & 24 & $S\left(160^{\circ}\right)$ \\
\hline $21-\mathrm{H}^{*}$ & $38.241 ;-85.692$ & Cherokee & --- & 45800 & 20.12 & 1.07 & 18 & $\operatorname{SE}\left(155^{\circ}\right)$ \\
\hline $21-\mathrm{R}^{*}$ & $38.241 ;-85.692$ & Cherokee & Year 0 & 0 & 0.00 & 2.30 & 18 & $\mathrm{~S}\left(168^{\circ}\right)$ \\
\hline $22-\mathrm{H}^{*}$ & $38.212 ;-85.707$ & Joe Creason & --- & 28600 & 14.25 & 13.19 & 12 & $\operatorname{SE}\left(146^{\circ}\right)$ \\
\hline $22-\mathrm{R}^{*}$ & $38.212 ;-85.707$ & Joe Creason & Year 0 & 0 & 0.00 & 9.99 & 9 & $\operatorname{SE}\left(142^{\circ}\right)$ \\
\hline
\end{tabular}

Denotes sites where plots were constructed as 5x20 meter long runs 
Table 4.2. Season groupings used for the best subset linear regression models. For the winter 2011, only three plots were sampled (H20, H21, H22). Because the H17 plot was constructed after the April 2011 sampling date, it was not included in the analyses for that month.

\begin{tabular}{ccc}
\hline \hline Season & Dates included & Plots included \\
\hline Winter 2011 & Feb 2011 & H20, H21, H22 \\
Spring 2011 & April 2011, May 2011 & April: all except H17; May: all plots \\
Summer 2011 & Aug 2011 & All plots \\
Fall 2011 & Oct 2011, Nov 2011 & All plots \\
Winter 2012 & Feb 2012 & All plots \\
Spring 2012 & April 2012 & All plots \\
\hline \hline
\end{tabular}


Table 4.3. Repeated measures analysis of variance results for nutrient and microbial biomass data. Honeysuckle presence, sampling date, and their interaction served as fixed factors in the first set of model while chronosequence, date, and their interactions were the fixed effects in the second model. Only honeysuckle shrub removal plots were used in the second model. The degrees of freedom are listed for each F statistic. All results presented in this table include the Joe Creason site.

\begin{tabular}{|c|c|c|c|c|c|c|}
\hline & \multicolumn{2}{|c|}{ Shrubs } & \multicolumn{2}{|c|}{ Date } & \multicolumn{2}{|c|}{ Shrubs x Date } \\
\hline & $\mathrm{F}_{1,171}$ & $\mathrm{P}$ & $\mathrm{F}_{7,173}$ & $\mathrm{P}$ & $\mathrm{F}_{7,171}$ & $\mathrm{P}$ \\
\hline $\mathrm{NH}_{4}^{+}$ & 0.27 & 0.60 & 10.59 & $<0.0001$ & 1.01 & 0.42 \\
\hline $\mathrm{NO}_{3}^{-}$ & 0.00 & 0.97 & 10.92 & $<0.0001$ & 0.95 & 0.47 \\
\hline Dissolved inorganic $\mathrm{N}$ & 0.66 & 0.42 & 30.27 & $<0.0001$ & 0.57 & 0.78 \\
\hline Dissolved organic C & 2.03 & 0.16 & 23.09 & $<0.0001$ & 0.63 & 0.73 \\
\hline Dissolved organic N & 0.48 & 0.49 & 9.64 & $<0.0001$ & 1.42 & 0.20 \\
\hline Microbial biomass $\mathrm{C}$ & 2.45 & 0.12 & 8.99 & $<0.0001$ & 0.29 & 0.96 \\
\hline \multirow[t]{3}{*}{ Microbial biomass $\mathrm{N}$} & 5.80 & 0.017 & 30.18 & $<0.0001$ & 0.54 & 0.81 \\
\hline & \multicolumn{2}{|c|}{ Chronosequence } & \multicolumn{2}{|c|}{ Date } & \multicolumn{2}{|c|}{ Chronosequence x Date } \\
\hline & $\mathrm{F}_{2,11}$ & $\mathrm{P}$ & $\mathrm{F}_{6,65}$ & $\mathrm{P}$ & $\mathrm{F}_{12,65}$ & $\mathrm{P}$ \\
\hline $\mathrm{NH}_{4}^{+}$ & 1.20 & 0.34 & 3.16 & 0.0089 & 1.52 & 0.14 \\
\hline $\mathrm{NO}_{3}^{-}$ & 0.41 & 0.67 & 4.31 & 0.0010 & 1.08 & 0.39 \\
\hline Dissolved inorganic $\mathrm{N}$ & 0.27 & 0.77 & 9.60 & $<0.0001$ & 1.37 & 0.20 \\
\hline Dissolved organic C & 1.15 & 0.35 & 5.85 & $<0.0001$ & 1.03 & 0.43 \\
\hline Dissolved organic $\mathrm{N}$ & 0.84 & 0.46 & 5.11 & 0.0002 & 1.59 & 0.12 \\
\hline Microbial biomass $\mathrm{C}$ & 1.40 & 0.29 & 5.63 & $<0.0001$ & 2.09 & 0.029 \\
\hline Microbial biomass $\mathrm{N}$ & 2.35 & 0.14 & 18.49 & $<0.0001$ & 4.67 & $<0.001$ \\
\hline
\end{tabular}


Table 4.4. Relationships between nutrient pools and environmental variables. Parentheses enclose standard errors for the intercept and regression coefficients. The models shown were found to be significant $(\mathrm{p} \leq 0.05)$ using the false discovery rate for multiple comparisons. Asterisks are used to indicate coefficients that were found to be statistically significant $(p \leq 0.05)$.

\begin{tabular}{|c|c|c|c|c|c|c|c|c|c|c|}
\hline & \multirow[b]{2}{*}{ Intercept } & \multicolumn{7}{|c|}{ Regression Coefficients } & \multirow[b]{2}{*}{ Adj. $R^{2}$} & \multirow[b]{2}{*}{ p-value } \\
\hline & & HS Stem & Tree BA & $\%$ Herb Cover & $\%$ Bare Soil & Northness & Eastness & Soil $\mathrm{H}_{2} \mathrm{O}$ & & \\
\hline \multicolumn{11}{|l|}{ Spring 2011} \\
\hline $\mathrm{NH}_{4}^{+}$ & $\begin{array}{c}2.17 \\
(1.419)\end{array}$ & & & $\begin{array}{c}-1.62 \\
(1.125)\end{array}$ & & & $\begin{array}{l}-1.20 * \\
(0.528)\end{array}$ & $\begin{array}{r}6.62 * \\
(2.783)\end{array}$ & 0.12 & 0.0243 \\
\hline${ }^{\mathrm{a}} \mathrm{NO}_{3}^{-}$ & $\begin{array}{l}-38.81 \\
(9.925)\end{array}$ & & $\begin{array}{r}0.56^{*} \\
(0.206)\end{array}$ & $\begin{array}{l}15.48^{*} \\
(6.817)\end{array}$ & & & & $\begin{array}{c}110.05^{*} \\
(17.319)\end{array}$ & 048 & $<0.0001$ \\
\hline${ }^{\mathrm{a}}$ DIN & $\begin{array}{c}-36.39 \\
(10.375)\end{array}$ & & $\begin{array}{c}0.55^{*} \\
(0.215)\end{array}$ & $\begin{array}{l}14.58^{*} \\
(7.126)\end{array}$ & & & & $\begin{array}{c}116.03 * \\
(18.104)\end{array}$ & 0.48 & $<0.0001$ \\
\hline${ }^{\mathrm{a}} \mathrm{DOC}$ & $\begin{array}{c}72.90 \\
(34.600)\end{array}$ & & $\begin{array}{c}1.67 \\
(0.740)\end{array}$ & $\begin{array}{c}45.56^{*} \\
(24.424)\end{array}$ & $\begin{array}{c}141.92 * \\
(54.247)\end{array}$ & & & & 0.19 & 0.0041 \\
\hline${ }^{\mathrm{a}} \mathrm{DON}$ & $\begin{array}{c}-18.24 \\
(11.127)\end{array}$ & & $\begin{array}{c}0.40 \\
(0.233)\end{array}$ & & & & & $\begin{array}{c}60.19^{*} \\
(19.955)\end{array}$ & 0.15 & 0.0054 \\
\hline${ }^{\mathrm{a}} \mathrm{MB}-\mathrm{C}$ & $\begin{array}{c}118.45 \\
(91.325)\end{array}$ & & & & $\begin{array}{r}579.69 * \\
(159.070)\end{array}$ & & & & 0.19 & 0.0006 \\
\hline${ }^{\mathrm{a}} \mathrm{MB}-\mathrm{N}$ & $\begin{array}{c}32.83 \\
(30.026)\end{array}$ & & & & $\begin{array}{l}141.95^{*} \\
(52.300)\end{array}$ & & & & 0.11 & 0.0090 \\
\hline \multicolumn{11}{|c|}{ Summer 2011} \\
\hline${ }^{\mathrm{a}} \mathrm{MB}-\mathrm{C}$ & $\begin{array}{c}-941.87 \\
(380.390)\end{array}$ & & & & $\begin{array}{r}564.89 * \\
(209.969)\end{array}$ & & & $\begin{array}{l}2590.16^{*} \\
(794.231)\end{array}$ & 0.35 & 0.0019 \\
\hline${ }^{\mathrm{a}} \mathrm{MB}-\mathrm{N}$ & $\begin{array}{l}-261.07 \\
(68.329)\end{array}$ & & & & $\begin{array}{c}68.24 \\
(37.717)\end{array}$ & & & $\begin{array}{c}818.09 * \\
(142.667)\end{array}$ & 0.39 & 0.0010 \\
\hline
\end{tabular}

\footnotetext{
a indicates nutrient pool that was found to have at least one influential data point.
} 
Table 4.4 cont.

\begin{tabular}{|c|c|c|c|c|c|c|c|c|c|c|}
\hline & \multirow[b]{2}{*}{ Intercept } & \multicolumn{7}{|c|}{ Regression Coefficients } & \multirow[b]{2}{*}{ Adj. $R^{2}$} & \multirow[b]{2}{*}{ p-value } \\
\hline & & HS Stem & Tree BA & $\%$ Herb Cover & $\%$ Bare Soil & Northness & Eastness & Soil $\mathrm{H}_{2} \mathrm{O}$ & & \\
\hline \multicolumn{11}{|l|}{ Fall 2011} \\
\hline${ }^{\mathrm{a}}$ DOC & $\begin{array}{c}11.77 \\
(58.501)\end{array}$ & & & & & $\begin{array}{c}-44.86 \\
(26.477)\end{array}$ & $\begin{array}{r}42.73^{*} \\
(19.998)\end{array}$ & $\begin{array}{c}640.89^{*} \\
(162.881)\end{array}$ & 0.24 & 0.0006 \\
\hline MB-C & $\begin{array}{c}327.07 \\
(166.587)\end{array}$ & & & & $\begin{array}{l}-369.21 * \\
(136.634)\end{array}$ & & $\begin{array}{c}41.20 \\
(32.261)\end{array}$ & $\begin{array}{c}666.94 \\
(397.866)\end{array}$ & 0.38 & $<0.0001$ \\
\hline MB-N & $\begin{array}{c}6.69 \\
(20.177)\end{array}$ & & & & $\begin{array}{c}-25.60 \\
(16.604)\end{array}$ & $\begin{array}{c}-9.69 \\
(5.478)\end{array}$ & $\begin{array}{c}6.85 \\
(4.125)\end{array}$ & $\begin{array}{l}153.49^{*} \\
(48.191)\end{array}$ & 0.42 & $<0.0001$ \\
\hline \multicolumn{11}{|l|}{ Winter 2012} \\
\hline $\mathrm{NO}_{3}^{-}$ & $\begin{array}{c}-8.58 \\
(13.761)\end{array}$ & & & & & & & $\begin{array}{r}82.00^{*} \\
(32.843)\end{array}$ & 0.16 & 0.0192 \\
\hline DIN & $\begin{array}{c}3.16 \\
(11.882)\end{array}$ & & & & & & & $\begin{array}{r}69.32 * \\
(28.357)\end{array}$ & 0.16 & 0.022 \\
\hline${ }^{\mathrm{a}} \mathrm{DOC}$ & $\begin{array}{c}94.66 \\
(58.970)\end{array}$ & & $\begin{array}{c}1.56 \\
(1.133)\end{array}$ & & $\begin{array}{r}261.42 * \\
(110.027)\end{array}$ & & & & 0.18 & 0.0328 \\
\hline $\mathrm{MB}-\mathrm{C}$ & $\begin{array}{c}-350.97 \\
(226.779)\end{array}$ & & & & $\begin{array}{c}506.28 \\
(256.659)\end{array}$ & & & $\begin{array}{c}1716.92^{*} \\
(370.368)\end{array}$ & 0.42 & 0.0004 \\
\hline MB-N & $\begin{array}{l}-167.95 \\
(44.253)\end{array}$ & & & & $\begin{array}{c}157.19^{*} \\
(50.083)\end{array}$ & & & $\begin{array}{c}475.64^{*} \\
(72.272)\end{array}$ & 0.61 & $<0.0001$ \\
\hline \multicolumn{11}{|l|}{ Spring 2012} \\
\hline DOC & $\begin{array}{c}-206.18 \\
(141.729)\end{array}$ & & & & $\begin{array}{r}423.83^{*} \\
(181.997)\end{array}$ & $\begin{array}{c}52.43 \\
(37.774)\end{array}$ & & $\begin{array}{r}665.14^{*} \\
(228.610)\end{array}$ & 0.25 & 0.019 \\
\hline${ }^{\mathrm{a}} \mathrm{DON}$ & $\begin{array}{c}-3.22 \\
(11.978)\end{array}$ & $\begin{array}{c}-0.00040 \\
(0.000229)\end{array}$ & & & $\begin{array}{r}47.25^{*} \\
(19.169)\end{array}$ & & & & 0.22 & 0.018 \\
\hline${ }^{\mathrm{a}} \mathrm{MB}-\mathrm{C}$ & $\begin{array}{c}-42.37 \\
(136.580)\end{array}$ & $\begin{array}{r}0.0068 * \\
(0.00255)\end{array}$ & $\begin{array}{c}3.45 \\
(2.222)\end{array}$ & $\begin{array}{c}129.92 \\
(64.511)\end{array}$ & $\begin{array}{r}559.44 * \\
(198.129)\end{array}$ & & & & 0.33 & 0.0092 \\
\hline${ }^{\mathrm{a}} \mathrm{MB}-\mathrm{N}$ & $\begin{array}{c}-20.54 \\
(30.082)\end{array}$ & $\begin{array}{c}0.0015^{*} \\
(0.000562)\end{array}$ & $\begin{array}{c}1.28^{*} \\
(0.489)\end{array}$ & $\begin{array}{c}42.30 * \\
(14.208)\end{array}$ & $\begin{array}{c}117.68^{*} \\
(43.638)\end{array}$ & & & & 0.41 & 0.0026 \\
\hline
\end{tabular}




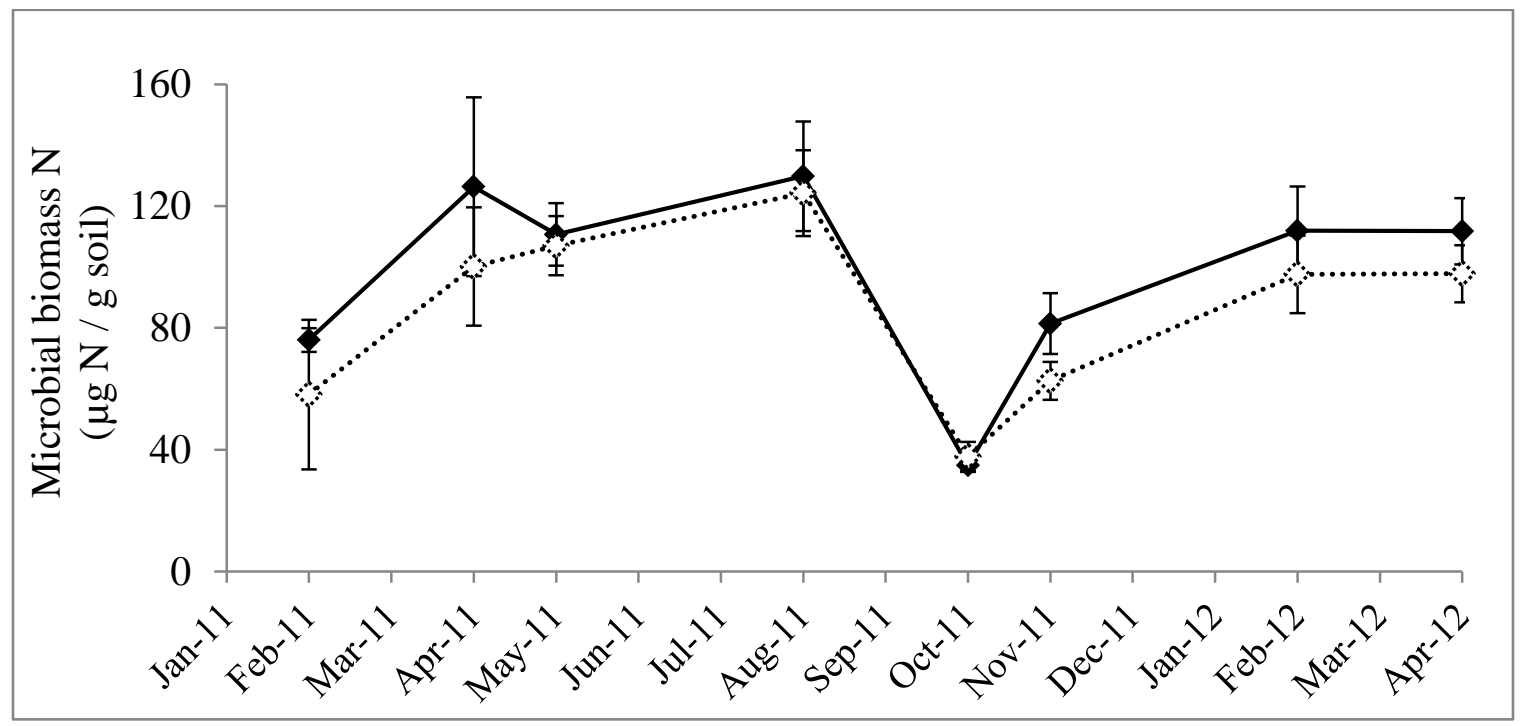

Fig 4.1. Changes over time in microbial biomass nitrogen for honeysuckle present (black) and honeysuckle removed (dotted) plots. February $2011(n=3)$ and April $2011(n=13)$ had fewer sites included than the remaining sampling dates $(n=14)$. Points are means $( \pm S E)$ at each sample date. No significant differences were observed between shrub present and shrub removal plots within any particular date. 

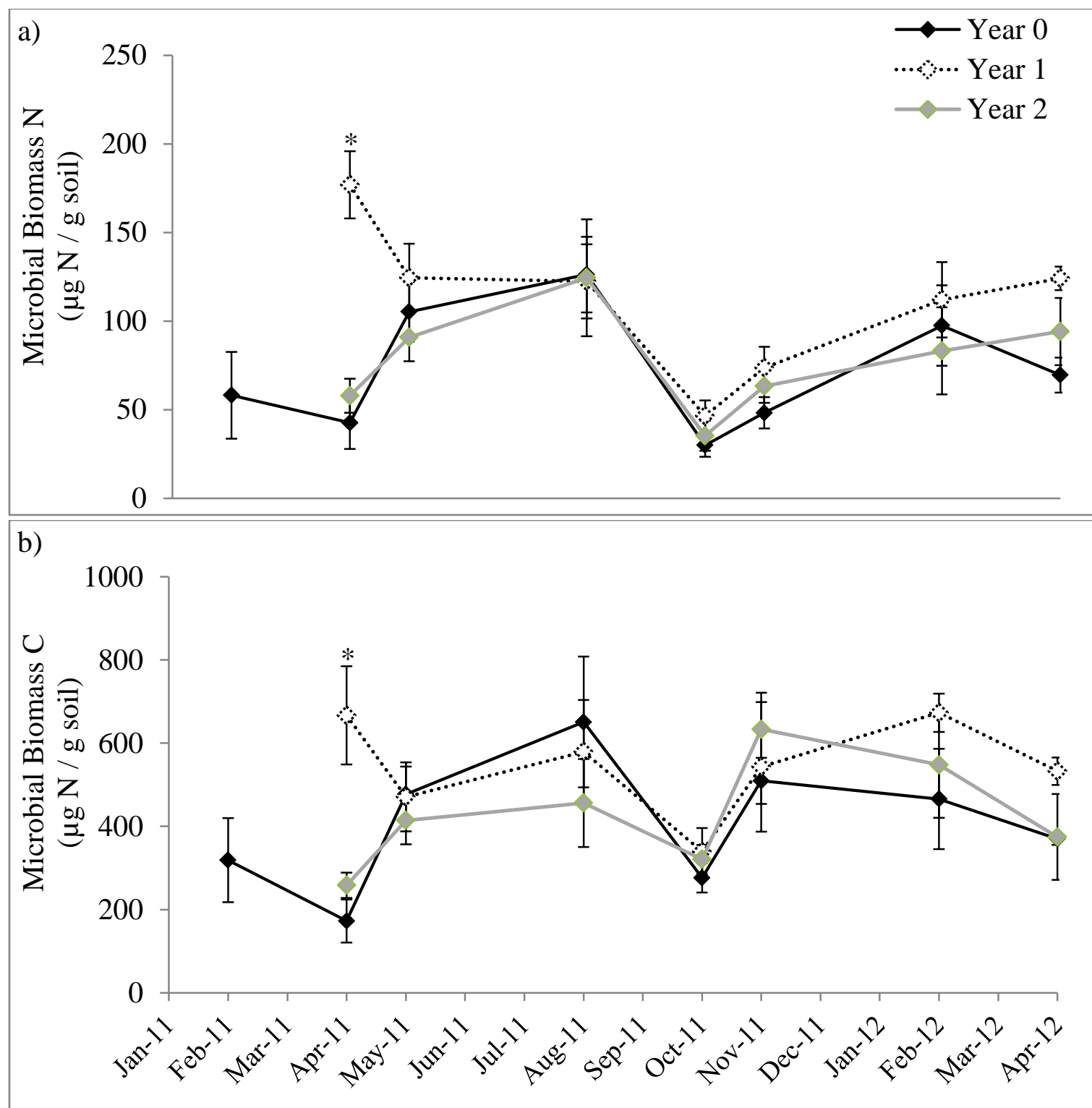

Fig 4.2. Changes over time in a) microbial biomass nitrogen (MC-N) and b) microbial biomass carbon (MB-C) in each of the chronosequence removals. Honeysuckle removal plots were categorized into Year 0 (cut in Feb 2011), Year 1 (cut between Nov 2009 and Mar 2010), and Year 2 (cut between Dec 2008 and Jan 2009) in the chronosequence. Points are means $( \pm$ SE) at each sample date. Note that the $y$ axis differs between MB-C and MB-N. Significant differences between chronosequences within any particular date are marked with an asterisk $(p \leq 0.05)$. 


\section{REFERENCES}

Aber JD, Melillo JM (1980) Litter decomposition: measuring relative contributions of organic matter and nitrogen to forest soils. Can J Bot 58:416-421.

Addison JA (2009) Distribution and impacts of invasive earthworms in Canadian forest ecosystems. Biol Invasions 11:59-79.

Aerts R (1997) Climate, leaf litter chemistry and leaf litter decomposition in terrestrial ecosystems: a triangular relationship. Oikos 79:439-449.

Akaike H (1973) Information theory and an extension of the maximum likelihood principle. In: Petrov BN, Csaki F (eds) Second international symposium on information theory, Akademai Kiado, Budapest pp 267-281.

Alberti M, Marzluff, JM, Shulenberger E, Bradley G, Ryan C, Zumbrunnen C (2003) Integrating humans into ecology: Opportunities and challenges for studying urban ecosystems. BioScience 53:1169-1179.

Anderson JM (1973) The breakdown and decomposition of sweet chestnut (Castanea sativa Mill.) and beech (Fagus sylvatica L.) leaf litter in two deciduous woodland soils. Oecologia 12:251-274.

Arthur MA, Bray SR, Kuchle CR, McEwan RW (2012) The influence of the invasive shrub, Lonicera maackii, on leaf decomposition and microbial community dynamics. Plant Ecol 213:1571-1582.

Ashton IW, Hyatt LA, Howe KM, Gurevitch J, Lerdau MT (2005) Invasive species accelerate decomposition and litter nitrogen loss in a mixed deciduous forest. Ecol App 15:1263-1272.

Bardgett RD, Freeman C, Ostle NJ (2008) Microbial contributions to climate change through carbon cycle feedbacks. ISME J 2:805-814.

Bartuszevige AM, Gorchov DL (2006) Avian seed dispersal of an invasive shrub. Biol Invasions 8:1013-1022.

Bartuszevige AM, Gorchov DL, Raab L (2006) The relative importance of landscape and community features in the invasion of an exotic shrub in a fragmented landscape. Ecography 29:213-222. 
Bartuszevige AM, Hrenko RL, Gorchov DL (2007) Effects of leaf litter on establishment, growth and survival of invasive plant seedlings in a deciduous forest. Am Midl Nat $158: 472-477$.

Bauhus J, Pare D, Cote L (1998) Effects of tree species, stand age and soil type on soil microbial biomass and its activity in a southern boreal forest. Soil Biol Biochem 30:1077-1089.

Benjamini Y, Hochberg Y (1995) Controlling the false discovery rate: a practical and powerful approach to multiple testing. J R Stat Soc Ser B Methodol 57:289-300.

Berg B, Staaf H (1981) Leaching, accumulation and release of nitrogen in decomposing forest floor litter. In: Clark FE, Rosswall T (eds) Terrestrial nitrogen cycles: processes, ecosystem strategies, and management impacts. Ecol Bull 33:163-178.

Bever JD, Dickie IA, Facelli E, Facelli JM, Klironomos JN, Moora M, Rillig MC, Stock WD, Tibbett M, Zobel M (2010) Rooting theories of plant community ecology in microbial interactions. Trends Ecol Evol 25:468-478.

Blair BC, Stowasser A (2009) Impact of Lonicera maackii on decomposition rates of native leaf litter in a southwestern Ohio woodland. Ohio J Sci 109:43-47.

Blair JM, Parmelee RW, Beare MH (1990) Decay rates, nitrogen fluxes, and decomposer communities of single-and mixed-species foliar litter. Ecology 71:1976-1985.

Boege K, Marquis R (2005) Facing herbivory as you grow up: the ontogeny of resistance in plants. Trends Ecol Evol 20:441-448.

Bohlen PJ (2006) Biological invasions: Linking the aboveground and belowground consequences. Appl Soil Ecol 32:1-5.

Bohlen PJ, Edwards CA (1995) Earthworm effects on N dynamics and soil respiration in microcosms receiving organic and inorganic nutrients. Soil Biol Biochem 27:341348.

Bohlen PJ, Groffman PM, Fahey TJ, Fisk MC, Suárez E, Pelletier DM, Fahey RT (2004a) Ecosystem consequences of exotic earthworm invasion of north temperate forests. Ecosystems 7:1-12.

Bohlen PJ, Parmelee RW, Allen MF, Ketterings QM (1999) Differential effects of earthworms on nitrogen cycling from various nitrogen-15-labeled substrates. Soil Sci Soc Am J 63:882-890.

Bohlen PJ, Pelletier DM, Groffman PM, Fahey TJ, Fisk MC (2004b) Influence of earthworm invasion on redistribution and retention of soil carbon and nitrogen in northern temperate forests. Ecosystems 7:13-27. 
Bohlen PJ, Scheu S, Hale CM, McLean MA, Migge S, Groffman PM, Parkinson D (2004c) Non-native invasive earthworms as agents of change in northern temperate forests. Front Ecol Environ 2:427-435.

Borgmann KL, Rodewald AD (2004) Nest predation in an urbanizing landscape: the role of exotic shrubs. Ecol Appl 14:1757-1765.

Borgmann KL, Rodewald AD (2005) Forest restoration in urbanizing landscapes: Interactions between land uses and exotic shrubs. Restor Ecol 13:334-340.

Bouché MB (1977) Strategies lombriciennes. In: Lohm U, Persson T (eds) Soil organisms as components of ecosystems. Proceedings of the VI International Soil Zoology Colloquium of the International Society of Soil Science (ISSS), Swedish Natural Science Research Council, Stockholm, pp 122-132.

Bradford MA, Tordoff GM, Eggers T, Jones TH, Newington JE (2002) Microbiota, fauna, and mesh size interactions in litter decomposition. Oikos 99:317-323.

Brookes PC, Landman A, Pruden G, Jenkinson DS (1985) Chloroform fumigation and the release of soil nitrogen: a rapid direct extraction method to measure microbial biomass nitrogen in soil. Soil Biol Biochem 17:837-842.

Buddle CM, Higgins S, Rypstra (2004) Ground-dwelling spider assemblages inhabiting riparian forests and hedgerow in an agricultural landscape. Am Midl Nat 151:15-26

Burnham K P, Anderson DR (2002) Model selection and multimodel inference: A practical information-theoretic approach. Springer-Verlag, New York.

Burtelow AE, Bohlen PJ, Groffman PM (1998) Influence of exotic earthworm invasion on soil organic matter, microbial biomass and denitrification potential in forest soils of the northeastern United States. Appl Soil Ecol 9:197-202.

Butterbach-Bahl K, Gundersen P (2011) Nitrogen processes in terrestrial ecosystems. In: Sutton MA, Howard CM, Erisman JW, Billen G, Bleeker A, Grennfelt P, Grinsven H, Grizzetti B (eds) The European Nitrogen Assessment: Sources, Effects and Policy Perspectives, Cambridge University Press, New York, pp 99-125.

Callaway RM, Thelen GC, Rodriguez A, Holben WE (2004) Soil biota and exotic plant invasion. Nature 427:731-733.

Carreiro MM, Sinsabaugh RL, Repert DA, Parkhurst DF (2000) Microbial enzyme shifts explain litter decay responses to simulated nitrogen deposition. Ecology 81:23592365. 
Carreiro MM, Zipperer WC (2011) Co-adapting societal and ecological interactions following large disturbances in urban park woodlands. Austral Ecol 36:904-915.

Castellano SM, Gorchov DL (2013) White-tailed deer (Odocoileus virginianus) disperse seeds of the invasive shrub, Amur honeysuckle (Lonicera maackii). Nat Areas J 33:78-80.

Chapin III FS, Vitousek PM, van Cleve K (1986) The nature of nutrient limitation in plant communities. Am Nat 127:48-58.

Christopher CC, Cameron GN (2012) Effects of invasive amur honeysuckle (Lonicera maackii) and white tailed deer (Odocoileus virginianus) on litter-dwelling arthropod communities. Am Midl Nat 167:256-272.

Cipollini, D, Stevenson R, Cipollini K (2008a) Contrasting effects of allelochemical from two invasive plants on the performance of a nonmycorrhizal plant. Int J Plant Sci 169:371-375.

Cipollini D, Stevenson R, Enright S, Eyles A, Bonello P (2008b) Phenolic metabolites in leaves of the invasive shrub, Lonicera maackii, and their potential phytotoxic and anti-herbivore effects. J Chem Ecol 34:144-152.

Clapperton MJ, Baker GH, Fox CA (2007) Earthworms. In: Carter MR, Gregorich EG (eds) Soil Sampling and Methods of Analysis, 2nd ed. CRC Press, Boca Raton, pp 427-444.

Collier MH, Vankat JL, Hughes MR (2002) Diminished plant richness and abundance below Lonicera maackii, an invasive shrub. Am Midl Nat 147:60-71.

Couteaux MM, Bottner P, Berg B (1995) Litter decomposition, climate and liter quality. Trends Ecol Evol 10:63-66.

Curry JP, Schmidt O (2007) The feeding ecology of earthworms - A review. Pedobiologia 50:463-477.

Deering RH, Vankat JL (1999) Forest colonization and developmental growth of the exotic shrub Lonicera maackii. Am Midl Nat 141:43-50.

Dempsey MA, Fisk MC, Fahey TJ (2011) Earthworms increase the ratio of bacteria to fungi in northern hardwood forest soils, primarily by eliminating the organic horizon. Soil Biol Biochem 43:2135-2141.

Devi NB, Yadava PS (2006) Seasonal dynamics in soil microbial biomass C, N and P in a mixed-oak forest ecosystem of Manipur, North-east India. Appl Soil Ecol 31:220227. 
Devliegher W, Verstraete W (1995) Lumbricus terrestris in a soil core experiment: nutrient-enrichment processes (NEP) and gut-associated processes (GAP) and their effect on microbial biomass and activity. Soil Biol Biochem 12:1573-1580.

Díaz-Raviña M, Acea MJ Caraballas T (1995) Seasonal changes in microbial biomass and nutrient flush in forest soils. Biol Fert Soils 19:220-226.

Díaz-Raviña M, Caraballas T, Acea MJ (1988) Microbial biomass and activity in four acid soils. Soil Biol Biochem 20:817-823.

Dindal, DL (1990) Soil biology guide. Wiley-Interscience, New York.

Doane TA, Horwath WR (2003) Spectrophotometric determination of nitrate with a single reagent. Anal Lett 36:2713-2722

Dorning M, Cipollini D (2006) Leaf and root extracts of the invasive shrub, Lonicera maackii, inhibit seed germination of three herbs with no autotoxic effects. Plant Ecol 184:287-296.

Dotson DB, Kalisz PJ (1989) Characteristics and ecological relationships of earthworm assemblages in undisturbed forest soils in the southern Appalachians of Kentucky, USA. Pedobiologia 33:211-220.

Dutra HP, Barnett K, Reinhardt JR, Marquis RJ, Orrock JL (2011) Invasive plant species alter consumer behavior by providing refuge from predation. Oecologia 166:649-657.

Edwards CA, Bohlen PJ (1996) Biology and ecology of earthworms. 3rd ed. Chapman and Hall, London.

Ehrenfeld JG (2003) Effects of exotic plant invasions on soil nutrient cycling processes. Ecosystems 6:503-523.

Ehrenfeld JG (2010) Ecosystem consequences of biological invasions. Ann Rev Ecol Evol and Syst 41:59-80.

Ehrenfeld JG, Kourtev P, Huang W (2001) Changes in soil function following invasions of exotic understory plants in deciduous forests. Ecol Appl 11:1287-1300.

Eisenhauer N, Partsch S, Parkinson D, Scheu S (2007) Invasion of a deciduous forest by earthworms: changes in soil chemistry, microflora, microarthropods and vegetation. Soil Biol Biochem 39:1099-1110.

Eppinga MB, Kaproth MA, Collins AR, Molofsky J (2011) Litter feedbacks, evolutionary change and exotic plant invasion. J Ecol 99:503-514. 
Evans RD, Rimer R, Sperry L, Belnap J (2001) Exotic plant invasion alters nitrogen dynamics in an arid grassland. Ecol Appl 11:1301-1310.

Fisk MC, Fahey TJ (2001) Microbial biomass and nitrogen cycling responses to fertilization and litter removal in young northern hardwood forests. Biogeochem 53:201-223.

Fisk MC, Fahey TJ, Groffman PM, Bohlen PJ (2004) Earthworm invasion, fine-root distributions, and soil respiration in north temperate forests. Ecosystems 7:55-62.

Frelich LE, Hale CM, Scheu S, Holdsworth AR, Heneghan L, Bohlen PJ, Reich PB (2006) Earthworm invasion into previously earthworm-free temperate and boreal forests. Biol Invasions 8:1235-1245.

Freund RJ, Littell RC (2000) SAS system for regression, 3rd ed. SAS Institute, Cary, NC.

Frey SD, Elliott ET, Paustian K, Peterson GA (2000) Fungal translocation as a mechanism for soil nitrogen inputs to surface residue decomposition in a no-tillage agroecosystem. Soil Biol Biochem 32:689-698.

Gartner TB, Cardon ZG (2004) Decomposition dynamics in mixed-species leaf litter. Oikos 104:230-246.

Gates GE (1966) Requiem for megadrile utopias. A contribution toward the understanding of the earthworm fauna of North America. Proc Biol Soc Wash 79:239-254.

Gates GE (1977) More on the earthworm genus, Diplocardia. Megadrilogica 3:1-48.

Gibson KD, Quackenbush PM, Emery NC, Jenkins MA, Kladivko EJ (2013) Invasive earthworms and plants in Indiana old- and second-growth forests. Invasive Plant Sci Manag 6:161-174.

Goodell K, McKinney AM, Lin CH (2010) Pollen limitation and local habitat-dependent pollinator interactions in the invasive shrub Lonicera maackii. Intern J Plant Sci 171:63-72.

Gorchov DL, Trisel DE (2003) Competitive effects of the invasive shrub, Lonicera maackii (Rupr.) Herder (Caprifoliaceae), on the growth and survival of native tree seedlings. Plant Ecol 166:13-24.

Gould AM, Gorchow DL (2000) Effects of the exotic invasive shrub Lonicera maackii on the survival and fecundity of three species of native annuals. Am Midl Nat 144:36-50.

Groffman PM, Bohlen PJ, Fisk MC, Fahey TJ (2004) Exotic earthworm invasion and microbial biomass in temperate forest soils. Ecosystems 7:45-54. 
Groffman PM, Zak DR, Christensen S, Mosier A, Tiedje JM (1993) Early spring nitrogen dynamics in a temperate forest landscape. Ecology 74:1579-1585.

Gundale MJ (2002) Influence of exotic earthworms on the soil organic horizon and the rare fern Botrychium mormo. Conserv Biol 16:1555-1561.

Hale CM, Frelich LE, Reich PB (2005a) Exotic European earthworm invasion dynamics in northern hardwood forests of Minnesota, USA. Ecol Appl 15:848-860.

Hale CM, Frelich LF, Reich PB, Pastor J (2005b) Effects of European earthworm invasion on soil characteristics in northern hardwood forests of Minnesota, USA. Ecosystems 8:911-927.

Hale CM, Frelich LE, Reich PB (2006) Changes in hardwood forest understory plant communities in response to European earthworm invasions. Ecology 87:1637-1649.

Harrington RA, Brown BJ, Reich PB (1989) Ecophysiology of exotic and native shrubs in southern Wisconsin. I. Relationship of leaf characteristics, resource availability, and phenology to seasonal patterns of carbon gain. Oecologia 80:356-367.

Hartman KM, McCarthy BC (2004) Restoration of a forest understory after the removal of an invasive shrub, Amur honeysuckle (Lonicera maackii). Restor Ecol 12:154-165.

Hartman KM, McCarthy BC (2007) A dendro-ecological study of forest overstorey productivity following the invasion of the non-indigenous shrub Lonicera maackii. Appl Veg Sci 10:3-14.

Hartman KM, McCarthy BC (2008) Changes in forest structure and species composition following invasion by a non-indigenous shrub, Amur honeysuckle (Lonicera maackii). J Torrey Bot Soc 135:245-259.

Hättenschwiler S, Vitousek PM (2000) The role of polyphenols in terrestrial ecosystem nutrient cycling. Trends Ecol Evol 15:238-243.

Hawkes CV, Belnap J, D’Antonio C, Firestone MK (2006) Arbuscular mycorrhizal assemblages in native plant roots change in the presence of invasive exotic grasses. Plant Soil 281:369-380.

Hawkes CV, Wren IF, Herman DJ, Firestone MK (2005) Plant invasion alters nitrogen cycling by modifying the soil nitrifying community. Ecol Lett 8:976-985.

Hector A, Beale AJ, Minns A, Otway SJ, Lawton JH (2000) Consequences of the reduction of plant diversity for litter decomposition: effects through litter quality and microenvironment. Oikos 90:357-371. 
van der Heijden MGA, Bardgett RD, van Straalen NM (2008) The unseen majority: soil microbes as drivers of plant diversity and productivity in terrestrial ecosystems. Ecol Lett 11:296-310.

Hendriksen NB (1990) Leaf litter selection by detritivore and geophagous earthworms. Biol Fertil Soils 10:17-21.

Hendrix PF, Baker GH, Callaham MA, Damoff GA, Fragoso C, González G, James SW, Lachnicht SL, Winsome T, Zu X (2006) Invasion of exotic earthworms into ecosystems inhabited by native earthworms. Biol Invasions 8:1287-1300.

Heneghan, L, Steffen J, Fagen K (2007) Interactions of an introduced shrub and introduced earthworms in an Illinois urban woodland: Impact on leaf litter decomposition. Pedobiologia 50:543-551.

Henrot J, Robertson GP (1994) Vegetation removal in two soils of the humid tropics: effect on microbial biomass. Soil Biol Biochem 26:111-116

Hidayati SN, Baskin JM, Baskin CC (2000) Dormancy-breaking and germination requirements of seeds of four Lonicera species (Caprifoliaceae) with underdeveloped spatulate embryos. Seed Sci Res 10:459-469.

Hidayati SN, Baskin JM, Baskin CC (2002) Effects of dry storage on germination and survivorship of seeds of four Lonicera species (Caprifoliaceae). Seed Sci Tech 30:137-148.

Holdsworth AR, Frelich LE, Reich PB (2007) Regional extent of an ecosystem engineer: Earthworm invasion in northern hardwood forests. Ecol Appl 17:1666-1677.

Holdsworth AR, Frelich LE, Reich PB (2008) Litter decomposition in earthworminvaded northern hardwood forests: Role of invasion degree and litter chemistry. Ecoscience 15:536-544.

Holdsworth AR, Frelich LE, Reich PB (2012) Leaf litter disappearance in earthworminvaded northern hardwood forests: role of tree species and the chemistry and diversity of litter. Ecosystems 15:913-926.

Hoorens B, Aerts R, Stroetenga M (2003) Does initial litter chemistry explain litter mixture effects on decomposition? Oecologia 137:578-586.

Hopfensperger KN, Leighton GM, Fahey TJ (2011) Influence of invasive earthworms on above and belowground vegetation in a northern hardwood forest. Am Midl Nat 166:53-62.

Horner JD, Gosz JR, Cates RG (1988) The role of carbon-based plant secondary metabolites in decomposition in terrestrial ecosystems. Am Nat 132:869-883. 
Hornsby DC, Lockaby BG, Chappelka AH (1995) Influence of microclimate on decomposition in loblolly pine stands: a field microcosm approach. Can J Forest Res 25:1570-1577.

Hulme PE (2009) Trade, transport and trouble: managing invasive species pathways in an era of globalization. J Appl Ecol 46:10-18.

Hutchinson TF, Vankat JL (1997) Invasibility and effects of amur honeysuckle in southwestern Ohio forests. Conserv Biol 11:1117-1124.

Hutchinson TF, Vankat JL (1998) Landscape structure and spread of the exotic shrub Lonicera maackii (Amur honeysuckle) in southwestern Ohio forests. Am Midl Nat 139:383-390.

Ingold JL, Craycraft MJ (1983) Avian frugivory on honeysuckle (Lonicera) in southwestern Ohio. Ohio J Sci 83:256-258.

Irmler $\mathrm{U}$ (2000) Changes in the fauna and its contribution to mass loss and $\mathrm{N}$ release during leaf litter decomposition in two deciduous forests. Pedobiologia 44:105-118.

James SW (2004) Planetary processes and their interactions with earthworm distribution. In: Edwards CA (ed) Earthworm Ecology. CRC Press, Boca Raton, pp 53-62.

James SW, Hendrix PF (2004) Invasion of exotic earthworms into North America and other regions. In: Edwards CA (ed) Earthworm Ecology, 2nd ed, CRC Press, Boca Raton, USA, pp 75-86.

Jenkinson DS, Ladd JN (1981) Microbial biomass in soil: measurement and turnover. In Paul EA, Ladd JN (eds) Soil Biochemistry, Vol. 5. Mercel Dekker, New York, pp 415-471.

Jordan NR, Larson DL, Huerd SC (2008) Soil modification by invasive plants: effects on native and invasive species of mixed-grass prairies. Biol Invasions 10:177-190.

Kalisz PJ, Dotson DB (1989) Land-use history and the occurrence of exotic earthworms in the mountains of eastern Kentucky. Am Midl Nat 122:288-297.

Kalisz PJ, Wood HB (1995) Native and exotic earthworms in wildland ecosystems. In: Hendrix, PF (ed) Earthworm Ecology and Biogeography in North America, CRC Press, Boca Raton, pp 117-127.

Kara Ö, Bolat İ, Çakiroğlu K, Öztürk M (2008) Plant canopy effects on litter accumulation and soil microbial biomass in two temperate forests. Biol Fertil Soils 45:193-198. 
Kaye JP, Hart SC (1997) Competition for nitrogen between plants and soil microorganisms. Trends Ecol Evol 12:139-143.

Kazakou E, Vile D, Shipley B, Gallet C, Garnier E (2006) Co-variations in litter decomposition, leaf traits and plant growth in species from a Mediterranean old-field succession. Funct Ecol 20:21-30.

Kazakou E, Violle C, Roumet C, Pintor C, Gimenez O, Garnier E (2009) Litter quality and decomposability of species from a Mediterranean succession depend on leaf traits but not on nitrogen supply. Ann Bot 104:1151-1161.

Kenward MG, Roger JH (1997) Small sample inference for fixed effects from restricted maximum likelihood. Biometrics 53:983-997.

Klebler, JE (2000) The Encyclopedia of Louisville. University of Kentucky Press, Lexington, KY.

Klironomos, JN (2002) Feedback with soil biota contributes to plant rarity and invasiveness in communities. Nature 417:67-70.

Kourtev PS, Ehrenfeld JG, Häggblom M (2002) Exotic plant species alter the microbial community structure and function in the soil. Ecology 83:3152-3166.

Kourtev PS, Ehrenfeld JG, Häggblom M (2003) Experimental analysis of the effect of exotic and native plant species on the structure and function of soil microbial communities. Soil Biol Biochem 35:895-905.

Kourtev PS, Huang WZ, Ehrenfeld JG (1999) Differences in earthworm densities and nitrogen dynamics in soils under exotic and native plant species. Biol Invasions $1: 237-245$.

Kowalchuk GA, Stephen JR (2001) Ammonia-oxidizing bacteria: a model for molecular microbial ecology. Ann Rev Microbiol 55:485-529.

Kuebbing SE, Nunez MA, Simberloff D (2013) Current mismatch between research and conservation efforts: The need to study co-occurring invasive plant species. Biol Conserv 160:121-129.

Lawrence B, Fisk MC, Fahey TJ, Suárez ER (2003) Influence of nonnative earthworms on mycorrhizal colonization of sugar maple (Acer saccharum). New Phytol 157:145153.

Leston LFV, Rodewald AD (2006) Are urban forests ecological traps for understory birds? An examination using Northern Cardinals. Biol Conserv 131:566-574. 
Levee AA (1992) Louisville's Olmsted park legacy: selective chronology for Cherokee, Iroqois and Shawnee Parks and the Parkways. Report in Louisville Olmsted Parks Conservancy archives.

Levine JM, Pachepsky E, Kendall BE, Yelenik SG, Lambers JHR (2006) Plant-soil feedbacks and invasive spread. Ecol Lett 9:1005-1014.

Levine JM, Vilà M, D'Antonio CM, Dukes JS, Grigulis K, Lavorel S (2003) Mechanisms underlying the impacts of exotic plant invasions. P R Soc B: Biol Sci 270:775-781.

Li X, Fisk MC, Fahey TJ, Bohlen PJ (2002) Influence of earthworm invasion on soil microbial biomass and activity in a northern hardwood forest. Soil Biol Biochem 34:1929-1937.

Liao C, Peng R, Luo Y, Zhou X, Wu X, Fang C, Chen J, Li B (2008) Altered ecosystem carbon and nitrogen cycles by plant invasion: a meta-analysis. New Phytol 177:706714.

Lieurance D, Cipollini D (2013) Exotic Lonicera species both escape and resist specialist and generalist herbivores in the introduced range in North America. Biol Invasions 15:1713-1724.

Louisville/Jefferson County Metropolitan Sewer District Rainfall Query (2014) Rainfall Conditions for Jefferson County, KY. http://www.msdlouky.org/aboutmsd/rainfall_ query.cfm. Accessed 2 March 2014.

Luken JO (1988) Population structure and biomass allocation of the naturalized shrub Lonicera maackii (Rupr.) Maxim. in forest and open habitats. Am Midl Nat 119:258267.

Luken JO (1990) Forest and pasture communities respond differently to cutting of exotic Amur honeysuckle (Kentucky). Restor Manag Notes 8:122-123.

Luken JO, Mattimiro DT (1991) Habitat-specific resilience of the invasive shrub Amur honeysuckle (Lonicera maackii) during repeated clipping. Ecol Appl 1:104-109.

Luken JO, Goessling N (1995) Seedling distribution and potential persistence of the exotic shrub Lonicera maackii in fragmented forests. Am Midl Natt 133:124-130.

Luken JO, Kuddes LM, Tholemeier TC (1997a) Response of understory species to gap formation and soil disturbance in Lonicera maackii thickets. Restor Ecol 5:229-235.

Luken JO, Kuddes LM, Tholemeier TC, Kunkel BA (1997b) Comparative responses of Lonicera maackii (Amur honeysuckle) and Lindera benzoin (Spicebush) to increased light. Am Midl Nat 138:331-343. 
Luken JO, Thieret JW (1996) Amur honeysuckle, its fall from grace. Bioscience 46:1824.

Luken JO, Tholemeier TC, Kuddes LM, Kunkel BA (1995) Performance, plasticity, and acclimation of the nonindigenous shrub Lonicera maackii (Caprifoliaceae) in contrasting light environments. Can J Bot 73:1953-1961.

Madritch MD, Lindroth RL (2009) Removal of invasive shrubs reduces exotic earthworm populations. Biol Invasions 11:663-671.

Mattos KJ, Orrock JL (2010) Behavioral consequences of plant invasion: an invasive plant alters rodent antipredator behavior. Behav Ecol 21:556-561.

McCusker CE, Ward MP, Brawn JD (2010) Seasonal responses of avian communities to invasive bush honeysuckles (Lonicera spp.). Biol Invasions 12:2459-2470.

McEwan RW, Arthur-Paratley LG, Rieske LK, Arthur MA (2010) A multiassay comparison of seed germination inhibition by Lonicera maackii and cooccuring native shrubs. Flora 205:475-483.

McEwan RW, Birchfield MK, Schoergendorfer A, Arthur MA (2009a) Phenology and freeze tolerance of the invasive shrub Amur honeysuckle and potential native competitors. J Torrey Bot Soc 136:212-220.

McEwan RW, Rieske LK, Arthur MA (2009b) Potential interactions between invasive woody shrubs and the gypsy moth (Lymantria dispar), an invasive insect herbivore. Biol Invasions 11:1053-1058.

McEwan RW, Arthur MA, Alverson SE (2012) Throughfall chemistry and soil nutrient effects of the invasive shrub Lonicera maackii in deciduous forests. Am Midl Nat 168:43-55.

McKinney AM, Goodell K (2010) Shading by invasive shrub reduces seed production and pollinator services in a native herb. Biol Invasions 12:2751-2763.

McKinney ML (2002) Urbanization, biodiversity, and conservation. BioScience 52:883890.

McLean MA, Parkinson D (1998) Impacts of the epigeic earthworm Dendrobaena octaedra on oribatid mite community diversity and microarthropod abundances in pine forest floor: a mesocosm study. Appl Soil Ecol 7:125-136.

McLean MA, Parkinson D (2000) Field evidence of the effects of the epigeic earthworm Dendrobaena octaedra on the micro-fungal community in pine forest floor. Soil Biol Biochem 32:351-360. 
McLean MA, Migge-Kleian S, Parkinson D (2006) Earthworm invasions of ecosystems devoid of earthworms: effects on soil microbes. Biol Invasions 8:1257-1273.

McNeish RE, Moore EM, Benbow ME, McEwan RW (2014) Removal of the invasive shrub, Lonicera maackii, from riparian forests influences headwater stream biota and ecosystem function. River Res. Applic. doi: 10.1002/rra.2808

Meentemeyer V (1978) Macroclimate and lignin control of litter decomposition rates. Ecology 59:465-472.

Meiners SJ (2007) Apparent competition: an impact of exotic shrub invasion on tree regeneration. Biol Invasion 9:849-855.

Melillo JM, Aber JD, Muratore JF (1982) Nitrogen and lignin control of hardwood leaf litter decomposition dynamics. Ecology 63:621-626.

Migge-Kleian S, McLean MA, Maerz JC, Heneghan L (2006) The influence of invasive earthworms on indigenous fauna in ecosystems previously uninhabited by earthworms. Biol Invasions 8:1275-1285.

Miller KE, Gorchov DL (2004) The invasive shrub, Lonicera maackii, reduces growth and fecundity of perennial forest herbs. Oecologia 139:359-375.

Moore AM (1986) Temperature and moisture dependence of decomposition rates of hardwood and coniferous leaf litter. Soil Biol Biochem 18:427-435.

Moore TR, Trofymow JA, Prescott CE, Fyles J, Titus BD (2006) Patterns of carbon, nitrogen and phosphorus dynamics in decomposing foliar litter in Canadian forests. Ecosystems 9:46-62.

Muller RN, Bormann FH (1976) Role of Erythronium americanum Ker. in energy flow and nutrient dynamics of a northern hardwood forest ecosystem. Science 193:11261128.

National Climatic Data Center (NCDC) (2011) Climatological Annual SummaryKentucky 2011. ISSN\# 0145-0433. Ashville, NC.

National Climatic Data Center (NCDC) (2012) Climatological Annual SummaryKentucky 2012. ISSN\# 0145-0433. Ashville, NC.

National Climatic Data Center (NCDC) (2013) Climatological Annual SummaryKentucky 2013. ISSN\#0145-0433. Ashville, NC.

Needham AE (1957) Components of nitrogenous excreta in the earthworms Lumbricus terrestris L. and Eisenia foetida (Savigny). Exp Biol 34:425-446 
Neter J, Wasserman W, Kuner MH (1990) Applied Linear Statistical Models, 3rd ed. Irwin, Boston, MA.

Newman GS, Arthur MA, Muller RN (2006) Above- and belowground net primary production in a temperate mixed deciduous forest. Ecosystems 9:317-329.

Nuzzo VA, Maerz JC, Blossey B (2009) Earthworm invasion as the driving force behind plant invasion and community change in northeastern North American forests. Conserv Biol 23:966-974.

Olsen C, Cholewa AF (2009) A guide to nonnative invasive plants inventoried in the north by forest inventory and analysis. In General Technical Report NRS-52 U.S. Department of Agriculture, Forest Service, Northern Research Station. Newtown Square, PA, pp 76-78.

Orrock JL, Christopher CC, Dutra HP (2012) Seed bank survival of an invasive species, but not of two native species, declines with invasion. Oecologia 168:1103-1110.

Parkin TB, Berry EC (1999) Microbial nitrogen transformations in earthworm burrows. Soil Biol Biochem 31:1765-1771.

Paul EA, Clark FE (1989) Soil microbiology and biochemistry. Academic Press, San Diego.

Pereira AP, Graca MAS, Molles M (1998) Leaf litter decomposition in relation to litter physio-chemical properties, fungal biomass, arthropod colonization, and geographical origin of plant species. Pedobiologia 42:316-327.

Pimentel D, Zuniga R, Morrison D (2005) Update on the environmental and economic costs associated with alien-invasive species in the United States. Ecol Econ 52:273288.

Poland TM, McCullough DG (2006) Emerald ash borer: Invasion of the urban forest and the threat to North America's ash resource. J For 104:118-124.

Polyakova O, Billor N (2007) Impact of deciduous tree species on litterfall quality, decomposition rates and nutrient circulation in pine stands. For Ecol Manag 253:1118.

Poulette MM and Arthur MA (2012) The impact of the invasive shrub Lonicera maackii on the decomposition dynamics of a native plant community. Ecol Appl 22:412-424.

Pouyat RV, Carreiro MM (2003) Controls on mass loss and nitrogen dynamics of oak leaf litter along an urban-rural land-use gradient. Oecologia 135:288-298. 
Reinhart KO, Packer A, van der Putten WH, Clay K (2003) Plant-soil biota interactions and spatial distribution of black cherry in its native and invasive ranges. Ecol Lett 6:1046-1050.

Reinhart KO, Callaway RM (2006) Soil biota and invasive plants. New Phytol 170:445457.

Reynolds JW (1994) The distribution of the earthworms (Oligochaeta) of Indiana: a case for the post-Quaternary introduction theory for megadrile migration in North America. Megadrilogica 5:13-32.

Rhine ED, Sims GK, Mulvaney RL, Pratt EJ (1998) Improving the Berthelot reaction for determining ammonium in soil extracts and water. Soil Sci Soc Am J 62:473-480.

Richardson AP (1974) Report of visit for the review of tornado damage in Cherokee Park, George Rogers Clark Park and associated parkways in Louisville, Kentucky, April 17-18, 1974. Report submitted to Louisville Parks and Recreation Department by Olmsted Associates, Inc. Brookline, MA. (In Louisville Metro Parks archives).

Roberts DW (1986) Ordination on the basis of fuzzy set theory. Vegetatio 66:123-31.

Rodewald AD (2009) Urban-associated habitat alteration promotes brood parasitism of Acadian Flycatchers. J Field Ornithol 80:234-241.

Rodewald AD, Shustack DP, Hitchcock LE (2010) Exotic shrubs as ephemeral ecological traps for nesting birds. Biol Invasions 12:33-39.

Rodríguez-Echeverría S, Afonso C, Correia M, Lorenzo P, Roiloa SR (2013) The effect of soil legacy on competition and invasion by Acacia dealbata Link. Plant Ecol 214:1139-1146.

Saetre P (1998) Decomposition, microbial community structure, and earthworm effects along a birch-spruce soil gradient. Ecol 79:834-846.

Salamanca EF, Kaneko N, Katagiri S (1998) Effects of leaf litter mixtures on the decomposition of Quercus serrata and Pinus densiflora using field and laboratory microcosm methods. Ecol Eng 10:53-73.

Schädler M, Brandl R (2005) Do invertebrate decomposers affect the disappearance rate of litter mixtures? Soil Biol Biochem 37:329-337.

Schlesinger WH, Bernhardt ES (2013) Biogeochemistry: an analysis of global change, 3rd ed. Academic Press, New York.

Schmidt KA, Whelan CJ (1999) Effects of exotic Lonicera and Rhamnus on songbird nest predation. Conserv Biol 13:1502-1506. 
Schönholzer F, Kohli L, Hahn D, Daniel O, Goez C, Zeyer J (1998) Effects of decomposition of leaves on bacterial biomass and on palatability to Lumbricus terrestris L. Soil Biol Biochem 30:1805-1813.

Schwarz G (1978) Estimating the dimension of a model. Ann Stat 6:461-464.

Scott-Denton LE, Rosenstiel TN, Monson RK (2006) Differential controls by climate and substrate over the heterotrophic and rhizospheric components of soil respiration. Glob Change Biol 12:205-216.

Seastedt TR (1984) The role of microarthropods in decomposition and mineralization processes. Annu Rev Entomol 29:25-46.

Simberloff D (2006) Invasional meltdown 6 years later: important phenomenon, unfortunate metaphor, or both? Ecol Lett 9:912-919.

Simberloff D (2011) Charles Elton: neither founder nor siren, but prophet. In: Richardson DM (ed) Fifty Years of Invasion Ecology: The Legacy of Charles Elton, Blackwell, West Sussex, pp 11-24.

Simberloff D, Von Holle B (1999) Positive interactions of nonindigenous species: invasional meltdown? Biol Invasions 1:21-32.

Sharma P, Rai SC, Sharma R, Sharma E (2004) Effects of land-use change on soil microbial C, N and P in a Himalayan watershed. Pedobiologia 48:83-92.

Share AJ (1976) Restoration of a tornado ravaged park. Landsc Arch 66:456-462.

Smetak KM, Johnson-Maynard JL, Lloyd JE (2007) Earthworm population density and diversity in different aged urban systems. Appl Soil Ecol 37:161-168.

Smith VC, Bradford MA (2003) Do non-additive effects on decomposition in litter-mix experiments result from differences in resource quality between litters? Oikos 102:235-242.

Sparling GP (1992) Ratio of microbial biomass carbon to soil organic carbon as a sensitive indicator of changes in soil organic matter. Aust J Soil Res 30:195-207.

Staaf H (1980a) Influence of chemical composition, addition of raspberry leaves, and nitrogen supply on decomposition rate and dynamics of nitrogen and phosphorus in beech leaf litter. Oikos 35:55-62.

Staaf H (1980b) Release of plant nutrients from decomposing leaf litter in a South Swedish beech forest. Holarctic Ecol 3:129-36. 
Stinson KA, Campbell SA, Powell JR, Wolfe BE, Callaway RM, Thelen GC, Hallett SG, Prati D, Klironomons JN (2006) Invasive plant suppresses the growth of native tree seedlings by disrupting belowground mutualisms. PLoS Biol 4:727-731.

Suárez ER, Pelletier DM, Fahey TJ, Groffman PM, Bohlen PJ, Fisk MC (2004) Effects of exotic earthworms on soil phosphorus cycling in two broadleaf temperate forests. Ecosystems 7:28-44.

Suárez ER, Fahey TJ, Yavitt JB, Groffman PM, Bohlen PJ (2006) Patterns of litter disappearance in a northern hardwood forest invaded by exotic earthworms. Ecol Appl 16:154-165.

Swab RM, Zhang L, Mitsch WJ (2008) Effect of hydrologic restoration and Lonicera maackii removal on herbaceous understory vegetation in a bottomland hardwood forest. Restor Ecol 16:453-463.

Szlavecz K, Placella SA, Pouyat RV, Groffman PM, Csuzdi C, Yesilonis I (2006) Invasive earthworm species and nitrogen cycling in remnant forest patches. Appl Soil Ecol 32:54-62.

Taylor LA, Arthur MA, Yanai RD (1999) Forest floor microbial biomass across a northern hardwood successional sequence. Soil Biol Biochem 31:431-439.

Templer P, Findlay S, Lovett G (2003) Soil microbial biomass and nitrogen transformations among five tree species of the Catskill Mountains, New York, USA. Soil Biol Biochem 35: 607-613.

Tessier JT, Raynal DJ (2003) Vernal nitrogen and phosphorus retention by forest understory vegetation and soil microbes. Plant Soil 256:443-453.

Tillinghast EK (1967) Excretory pathways of ammonia and urea in the earthworm Lumbricus terrestris L. J Exp Zool 166:295-300.

Trammell TLE, Carreiro MM (2011) Vegetation composition and structure of woody plant communities along urban interstate corridors in Louisville, KY, U.S.A. Urban Ecosyst 14:501-524.

Trammell TLE, Ralston HA, Scroggins SA, Carreiro MM (2012) Foliar production and decomposition rates in urban forests invaded by the exotic invasive shrub, Lonicera maackii. Biol Invasions 14:529-545.

Trisel DE, Gorchov DL (1994) Regional distribution, leaf phenology, and herbivory of the invasive shrub, Lonicera maackii. Bull Ecol Soc Am 75:231-232.

USDA NRCS (2014) Plants profile for Lonicera maackii (Amur honeysuckle). http://plants.usda.gov/core/profile?symbol=loma6. Accessed 23 February 2014. 
Vance ED, Brookes PC, Jenkinson DS (1987) Microbial biomass measurements in forest soils: the use of the chloroform fumigation incubation method for strongly acid soils. Soil Biol Biochem 19:697-702.

Vitousek PM, D’Antonio CM, Loope LL, Rejmanek M, Westbrooks R (1997) Introduced species: a significant component of human-caused global change. NZ J Ecol 21:1-16.

Vitousek PM, Howarth RW (1991) Nitrogen limitation on land and in the sea: How can it occur? Biogeochemistry 13:87-115.

Vitousek PM, Matson PA (1984) Mechanisms of nitrogen retention in forest ecosystems: a field experiment. Sci 225:51-52.

Vogelsang KM, Bever JD (2009) Mycorrhizal densities decline in association with nonnative plants and contribute to plant. Ecology 90:399-407.

Wang Z, Goonewardene LA (2004) The use of MIXED models in the analysis of animal experiments with repeated measures data. Can J Anim Sci 84:1-11.

Wardle DA (1992) A comparative assessment of factors which influence microbial biomass carbon and nitrogen levels in soil. Biol Rev 67:321-358.

Wardle DA, Bardgett RD, Klironomos JN, Setälä H, van der Putten WH, Wall DH (2004) Ecological linkages between aboveground and belowground biota. Science 304:1629-1633.

Wardle DA, Bonner KI, Nicholson KS (1997) Biodiversity and plant litter: experimental evidence which does not support the view that enhanced species richness improves ecosystem function. Oikos 79:247-258.

Watling JI, Hickman CR, Lee E, Wang K, Orrock JL (2011a) Extracts of the invasive shrub Lonicera maackii increase mortality and alter behavior of amphibian larvae. Oecologia 165:153-159.

Watling JI, Hickman CR, Orrock JL (2011b) Invasive shrub alters native forest amphibian communities. Biol Conserv 144:2597-2601.

Watling, J.I., C.R. Hickman, Orrock JL (2011c) Predators and invasive plants affect performance of amphibian larvae. Oikos 120:735-739.

Weintraub MN, Scott-Denton LE, Schmidt SK, Monson RK (2007) The effects of tree rhizodeposition on soil exoenzyme activity,dissolved organic carbon, and nutrient availability in a subalpine forest ecosystem. Oecologia 154:327-338. 
Whalen JK, Parmelee RW (1999) Quantification of nitrogen assimilation efficiencies and their use to estimate organic matter consumption by the earthworms Aporrectodea tuberculata (Eisen) and Lumbricus terrestris L. App Soil Ecol 13:199-208.

Whalen JK, Parmelee RW, Subler S (2000) Quantification of nitrogen excretion rates for three lumbricid earthworms using 15N. Biol Fertil Soils 32:347-352.

White RJ, Carreiro MM, Zipperer WC (2014) Woody plant communities along urban, suburban, and rural streams in Louisville, Kentucky, USA. Urban Ecosyst DOI 10.1007/s11252-014-0376-x

Wilcove DS, Rothstein D, Dubow J, Phillips A, Losos E (1998) Quantifying threats to imperiled species in the United States. BioScience 48:607-616.

Wilson HN, Arthur MA, Schörgendorfer A, Paratley RD, Lee BD, McEwan RW (2013) Site characteristics as predictors of Lonicera maackii in second-growth forests of central kentucky, USA. Nat Areas J 33:189-198.

Witkamp M (1966) Decomposition of leaf litter in relation to environment, microflora, and microbial respiration. Ecology 47:194-201.

Wolfe BE, Klironomos JN (2005) Breaking new ground: Soil communities and exotic plant invasion. Bioscience 55:477-487.

Wolters V, Joergensen RG (1992) Microbial carbon turnover in beech forest soils worked by Aporrectodea caliginosa (Savigny) (Oligochaeta: Lumbricidae). Soil Biol Biochem 24:171-177.

Zak DR, Grigal DF, Gleeson S, Tilman D (1990a) Carbon and nitrogen cycling during old-field succession: constraints on plant and microbial biomass. Biogeochemistry 11:111-129.

Zak DR, Groffman PM, Pregitzer KS, Christensen S, Tiedje JM (1990b) The vernal dam: plant-microbe competition for nitrogen in northern hardwood forests. Ecology 71: 651-656.

Zhu WX, Carreiro MM (2004) Temporal and spatial variations in nitrogen transformations in deciduous forest ecosystems along an urban-rural gradient. Soil Biol Biochem 36: 267-278.

Zipperer WC, Guntenspergen GR (2009) Vegetation composition and structure of forest patches along urban-rural gradients. In: McDonnell MJ, Hahs AK, Breuste JH (eds) Ecology of cities and towns: a comparative approach. Cambridge University Press, New York, pp 274-286. 
Zogg GP, Zak DR, Pregitzer KS, Burton AJ (2000) Microbial immobilization and the retention of anthropogenic nitrate in a northern hardwood forest. Ecology 81:18581866.

Zong Z, Makeschin F (2006) Differences of soil microbial biomass and nitrogen transformation under two forest types in central Germany. Plant Soil 283:287-297. 
APPENDICES 
Appendix 1. Correlation matrix for variables used to model total earthworm biomass. Variables include honeysuckle stem density, honeysuckle basal area, mean air temperature at soil surface, mean soil temperature at $10 \mathrm{~cm}$, mean soil moisture in the top $10 \mathrm{~cm}$ of soil, and depth to bedrock.

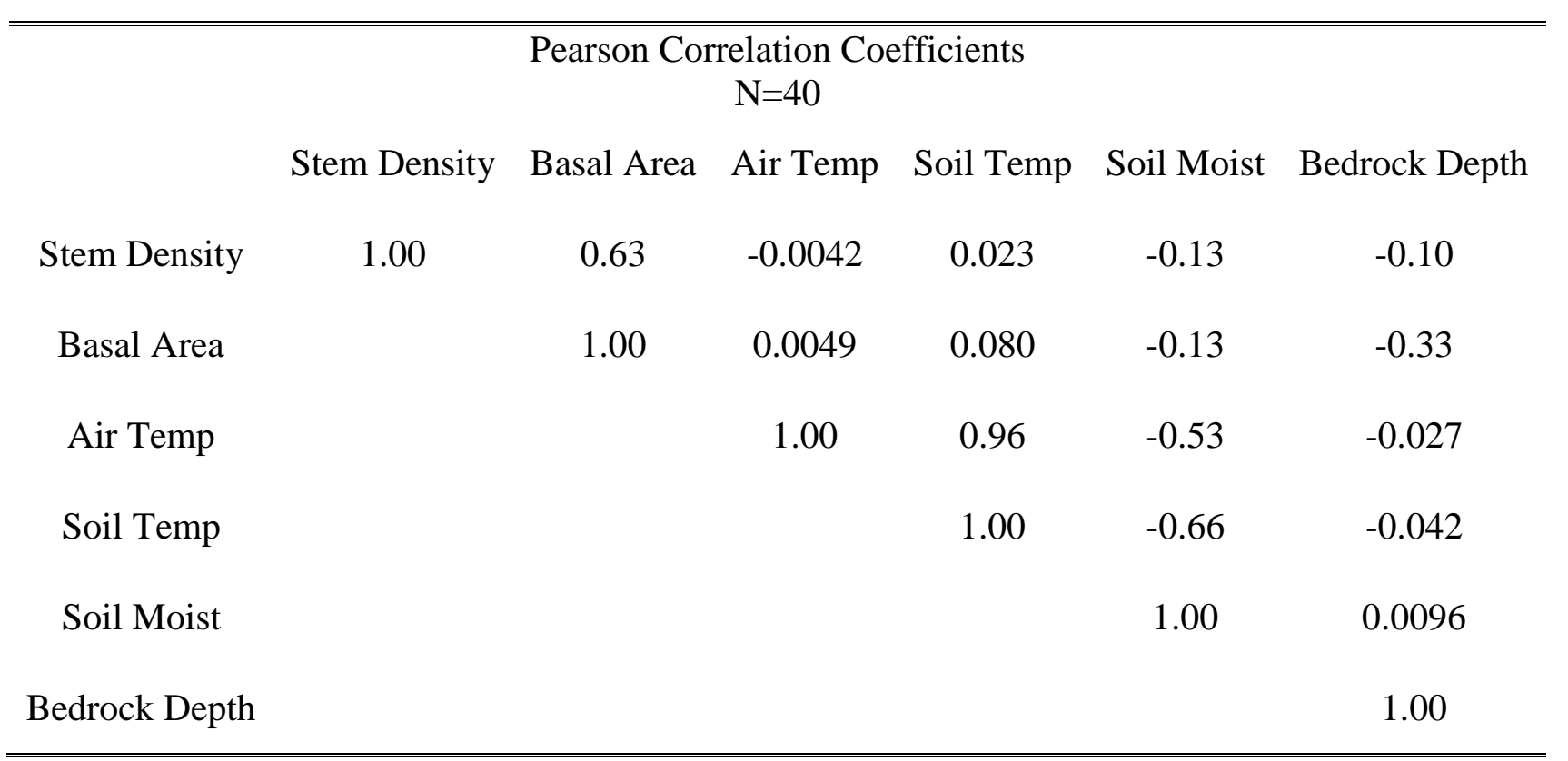


Appendix 2. Multiple regression models for total earthworm biomass at each date. Only honeysuckle present plots were used in this this analysis. The strongest model was selected using the Akaike Information Criterion (AIC). Models are indistinguishable if the difference of their AICs is less than 2. In these cases, Bayesian Information Criterion (BIC) was used as a tie-breaker for model selection. Blank cells indicate variables that were not used in the model. Bolded cells indicate the strongest model for each month.

\begin{tabular}{|c|c|c|c|c|c|c|c|c|}
\hline & AIC & $\mathrm{BIC}$ & $r^{2}$ & Intercept & Stem density Coeff. & $\begin{array}{c}\text { Soil temp } \\
\text { Coeff. }\end{array}$ & $\begin{array}{c}\text { Soil moist } \\
\text { Coeff. }\end{array}$ & $\begin{array}{c}\text { Bedrock depth } \\
\text { Coeff. }\end{array}$ \\
\hline \multicolumn{9}{|c|}{ Mar 2012} \\
\hline $\mathrm{m} 1$ & 29.64 & 32.75 & 0.135 & 13.691 & 0.000505432 & . & . & . \\
\hline $\mathrm{m} 2$ & 30.89 & 35.77 & 0.212 & -6.352 & 0.000415826 & 1.81072 & . & . \\
\hline $\mathrm{m} 3$ & 30.76 & 35.64 & 0.225 & 34.985 & 0.000078112 & . & -33.2684 & . \\
\hline m4 & 25.69 & 30.57 & 0.589 & 26.936 & 0.000413691 & • & • & -0.13433 \\
\hline $\mathrm{m} 5$ & 32.71 & 40.71 & 0.229 & 20.977 & 0.000164884 & 0.71547 & -23.7564 & . \\
\hline $\mathrm{m} 6$ & 27.35 & 35.35 & 0.606 & 40.131 & 0.000452501 & -1.03209 & . & -0.15229 \\
\hline $\mathrm{m} 7$ & 27.47 & 35.47 & 0.600 & 19.321 & 0.000585366 & . & 14.1393 & -0.14889 \\
\hline $\mathrm{m} 8$ & 29.34 & 42.45 & 0.606 & 35.801 & 0.000496496 & -0.86748 & 4.1333 & -0.15368 \\
\hline
\end{tabular}

$\stackrel{\nabla}{\nabla} \quad$ June 2012

\begin{tabular}{|c|c|c|c|c|c|c|c|c|}
\hline $\mathrm{m} 1$ & 21.2136 & 24.3247 & 0.00251 & 3.3589 & -0.000037988 & & & \\
\hline m2 & 17.6077 & 22.4877 & 0.50503 & 72.9017 & 0.00002047 & -3.19519 & . & . \\
\hline $\mathrm{m} 3$ & 23.1846 & 28.0646 & 0.00613 & 4.3031 & -0.000025943 & . & -6.5612 & . \\
\hline $\mathrm{m} 4$ & 23.1353 & 28.0153 & 0.01223 & 2.2931 & -0.000030606 & . & . & 0.01081 \\
\hline $\mathrm{m} 5$ & 16.8248 & 24.8248 & 0.65045 & 96.1057 & 0.000118065 & -3.96022 & -45.5363 & . \\
\hline m6 & 19.5862 & 27.5862 & 0.50636 & 72.1906 & 0.000022947 & -3.18071 & . & 0.004015 \\
\hline $\mathrm{m} 7$ & 25.1025 & 33.1025 & 0.01627 & 3.2684 & -0.000017693 & . & -6.9438 & 0.011053 \\
\hline $\mathrm{m} 8$ & 18.7949 & 31.906 & 0.65176 & 95.3998 & 0.000120506 & -3.94582 & -45.532 & 0.003973 \\
\hline \multicolumn{9}{|l|}{ ept 2012} \\
\hline $\mathrm{m} 1$ & 31.12 & 34.23 & 0.025 & 4.554 & 0.000223137 & . & . & . \\
\hline $\mathrm{m} 2$ & 25.24 & 30.12 & 0.636 & 141.585 & 0.000534234 & -6.73555 & . & . \\
\hline $\mathrm{m} 3$ & 31.95 & 36.83 & 0.158 & 13.828 & 0.000305619 & . & -42.8796 & . \\
\hline $\mathrm{m} 4$ & 29.83 & 34.71 & 0.354 & -7.102 & 0.000303872 & . & . & 0.11822 \\
\hline m5 & 20.38 & 28.38 & 0.846 & 162.616 & 0.000659607 & -7.19327 & -54.1867 & • \\
\hline m6 & 25.93 & 33.93 & 0.691 & 114.371 & 0.000522007 & -5.66275 & . & 0.05465 \\
\hline $\mathrm{m} 7$ & 31.82 & 39.82 & 0.354 & -7.889 & 0.000301155 & . & 2.3871 & 0.12096 \\
\hline $\mathrm{m} 8$ & 18.93 & 32.04 & 0.900 & 223.406 & 0.000768143 & -9.32944 & -92.154 & -0.09249 \\
\hline
\end{tabular}


Appendix 2. cont.

\begin{tabular}{|c|c|c|c|c|c|c|c|c|}
\hline & AIC & BIC & $\mathrm{r}^{2}$ & Intercept & $\begin{array}{l}\text { Stem density } \\
\text { Coeff. }\end{array}$ & $\begin{array}{l}\text { Soil temp } \\
\text { Coeff. }\end{array}$ & $\begin{array}{l}\text { Soil moist } \\
\text { Coeff. }\end{array}$ & $\begin{array}{l}\text { Bedrock depth } \\
\text { Coeff. }\end{array}$ \\
\hline \multicolumn{9}{|c|}{ Nov 2012} \\
\hline m1 & 26.61 & 29.72 & 0.115 & 0.000381965 & & . & . & 0.000381965 \\
\hline $\mathrm{m} 2$ & 26.93 & 31.81 & 0.282 & 0.000497468 & -1.88554 & 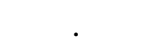 & . & 0.000497468 \\
\hline $\mathrm{m} 3$ & 27.63 & 32.51 & 0.217 & 0.000302033 & . & -28.425 & & 0.000302033 \\
\hline $\mathrm{m} 4$ & 28.19 & 33.07 & 0.160 & 0.000405538 & . & & 0.03452 & 0.000405538 \\
\hline m5 & 28.93 & 36.93 & 0.282 & 0.000489753 & -1.82727 & -1.474 & & 0.000489753 \\
\hline $\mathrm{m} 6$ & 28.88 & 36.88 & 0.286 & 0.000498066 & -1.76406 & & 0.01177 & 0.000498066 \\
\hline $\mathrm{m} 7$ & 29.62 & 37.62 & 0.218 & 0.000312436 & & -26.3319 & 0.00661 & 0.000312436 \\
\hline $\mathrm{m} 8$ & 30.88 & 43.99 & 0.287 & 0.00052027 & -1.90313 & 4.2168 & 0.01445 & 0.00052027 \\
\hline \multicolumn{9}{|c|}{ Mar 2013} \\
\hline $\mathrm{m} 1$ & 18.53 & 21.64 & 0.118 & 0.000234461 & & . & . & 0.000234461 \\
\hline $\mathrm{m} 2$ & 19.95 & 24.83 & 0.181 & 0.000258455 & -0.94407 & & . & 0.000258455 \\
\hline $\mathrm{m} 3$ & 10.91 & 15.79 & 0.735 & 0.000606986 & . & 36.2222 & & 0.000606986 \\
\hline $\mathrm{m} 4$ & 17.57 & 22.45 & 0.391 & 0.000269648 & . & . & 0.05152 & 0.000269648 \\
\hline m5 & 1.14 & 9.14 & 0.939 & 0.000704771 & -1.76046 & 41.3798 & . & 0.000704771 \\
\hline $\mathrm{m} 6$ & 19.39 & 27.39 & 0.405 & 0.000279208 & -0.46022 & & 0.0484 & 0.000279208 \\
\hline $\mathrm{m} 7$ & 12.19 & 20.19 & 0.758 & 0.000577628 & & 32.2313 & 0.01711 & 0.000577628 \\
\hline $\mathrm{m} 8$ & 2.64 & 15.75 & 0.943 & 0.000724703 & -1.88034 & 43.5354 & -0.00774 & 0.000724703 \\
\hline
\end{tabular}


Appendix 3. Correlation matrix for ammonium $\left(\mathrm{NH}_{4}\right)$, nitrate $\left(\mathrm{NO}_{3}\right)$, dissolved inorganic nitrogen (DIN), dissolved organic carbon (DOC), dissolved organic nitrogen (DON), microbial biomass carbon (MB-C), and microbial biomass nitrogen (MB-N).

\begin{tabular}{|c|c|c|c|c|c|c|c|}
\hline \multicolumn{8}{|c|}{$\begin{array}{l}\text { Pearson Correlation Coefficients } \\
\qquad N=200\end{array}$} \\
\hline & $\mathrm{NH}_{4}$ & $\mathrm{NO}_{3}$ & $\mathrm{DIN}$ & DOC & DON & MB-C & MB-N \\
\hline $\mathrm{NH}_{4}$ & 1.00 & -0.34 & -0.10 & 0.42 & -0.085 & -0.014 & 0.044 \\
\hline $\mathrm{NO}_{3}$ & & 1.00 & 0.97 & 0.19 & 0.71 & 0.13 & 0.019 \\
\hline DIN & & & 1.00 & 0.31 & 0.73 & 0.14 & 0.032 \\
\hline DOC & & & & 1.00 & 0.12 & 0.27 & 0.14 \\
\hline DON & & & & & 1.00 & 0.11 & 0.011 \\
\hline MB-C & & & & & & 1.00 & 0.69 \\
\hline MB-N & & & & & & & 1.00 \\
\hline
\end{tabular}


Appendix 4. Correlation matrix for variables used to model ammonium, total inorganic nitrogen, and microbial biomass N. Variables include honeysuckle stem density, honeysuckle shrub basal area (BA), tree BA, \% herbs, \% bare soil (arcsine transformed), aspect (expressed as northness and eastness), and gravimetric soil moisture content ( $\mathrm{soil}_{2} \mathrm{O}$ ).

\begin{tabular}{|c|c|c|c|c|c|c|c|c|}
\hline \multicolumn{9}{|c|}{$\begin{array}{l}\text { Pearson Correlation Coefficients } \\
\qquad \mathrm{N}=200\end{array}$} \\
\hline & HS Stem & HS BA & Tree BA & $\%$ Herbs & $\%$ Bare & North & East & Soil $\mathrm{H}_{2} \mathrm{O}$ \\
\hline HS Stem & 1.00 & 0.99 & -0.25 & -0.21 & 0.0043 & -0.15 & -0.051 & 0.064 \\
\hline HS BA & & 1.00 & -0.21 & -0.22 & 0.013 & -0.16 & -0.048 & 0.073 \\
\hline Tree BA & & & 1.00 & -0.17 & -0.0024 & -0.23 & 0.079 & 0.064 \\
\hline$\%$ Herbs & & & & 1.00 & 0.27 & 0.039 & -0.18 & 0.038 \\
\hline$\%$ Bare & & & & & 1.00 & -0.18 & -0.018 & -0.018 \\
\hline North & & & & & & 1.00 & 0.32 & -0.063 \\
\hline East & & & & & & & 1.00 & 0.034 \\
\hline Soil $\mathrm{H}_{2} \mathrm{O}$ & & & & & & & & 1.00 \\
\hline
\end{tabular}


Appendix 5. Nutrient and microbial biomass pools in honeysuckle shrub present and removed plots. Values are means $( \pm$ SE) expressed as $\mu \mathrm{g} \mathrm{N} \mathrm{g}^{-1}$ soil or $\mu \mathrm{g} \mathrm{C} \mathrm{g}^{-1}$ soil. Feb $2011(\mathrm{n}=3)$ and Apr $2011(\mathrm{n}=13)$ had fewer samples than the other dates (n=14).

\begin{tabular}{|c|c|c|c|c|c|c|c|c|}
\hline & Feb 2011 & Apr 2011 & May 2011 & Aug 2011 & Oct 2011 & Nov 2011 & Feb 2012 & Apr 2012 \\
\hline \multicolumn{9}{|l|}{ Shrubs present } \\
\hline $\mathrm{NH}_{4}^{+}$ & $\begin{array}{c}0.74 \\
(0.118)\end{array}$ & $\begin{array}{c}5.02 \\
(1.223)\end{array}$ & $\begin{array}{c}5.58 \\
(0.873)\end{array}$ & $\begin{array}{c}2.88 \\
(0.863)\end{array}$ & $\begin{array}{c}4.48 \\
(1.428)\end{array}$ & $\begin{array}{c}5.10 \\
(1.897)\end{array}$ & $\begin{array}{c}7.10 \\
(0.973)\end{array}$ & $\begin{array}{c}13.26 \\
(1.519)\end{array}$ \\
\hline $\mathrm{NO}_{3}^{-}$ & $\begin{array}{c}6.79 \\
(0.524)\end{array}$ & $\begin{array}{c}13.16 \\
(1.004)\end{array}$ & $\begin{array}{c}42.91 \\
(5.457)\end{array}$ & $\begin{array}{c}34.99 \\
(4087)\end{array}$ & $\begin{array}{l}44.06 \\
(6.097)\end{array}$ & $\begin{array}{c}41.53 \\
(3.638)\end{array}$ & $\begin{array}{c}24.80 \\
(4.589)\end{array}$ & $\begin{array}{c}18.64 \\
(5.308)\end{array}$ \\
\hline Dissolved inorganic $\mathrm{N}$ & $\begin{array}{c}7.52 \\
(0.406)\end{array}$ & $\begin{array}{c}18.18 \\
(1.729)\end{array}$ & $\begin{array}{l}48.48 \\
(5.670)\end{array}$ & $\begin{array}{c}37.87 \\
(3.969)\end{array}$ & $\begin{array}{l}48.54 \\
(5.252)\end{array}$ & $\begin{array}{c}46.63 \\
(3.229)\end{array}$ & $\begin{array}{c}31.90 \\
(4.054)\end{array}$ & $\begin{array}{c}31.89 \\
(4.272)\end{array}$ \\
\hline Dissolved organic C & $\begin{array}{c}53.28 \\
(5.537)\end{array}$ & $\begin{array}{l}185.03 \\
(8.021)\end{array}$ & $\begin{array}{c}213.27 \\
(23.838)\end{array}$ & $\begin{array}{c}151.78 \\
(15.040)\end{array}$ & $\begin{array}{c}187.50 \\
(16.118)\end{array}$ & $\begin{array}{c}324.27 \\
(45.897)\end{array}$ & $\begin{array}{c}274.63 \\
(22.122)\end{array}$ & $\begin{array}{c}273.60 \\
(41.932)\end{array}$ \\
\hline Dissolved organic $\mathrm{N}$ & $\begin{array}{c}4.31 \\
(0.673)\end{array}$ & $\begin{array}{c}7.00 \\
(0.853)\end{array}$ & $\begin{array}{c}22.37 \\
(5.553)\end{array}$ & $\begin{array}{c}20.49 \\
(3.259)\end{array}$ & $\begin{array}{c}28.98 \\
(4.778)\end{array}$ & $\begin{array}{c}17.93 \\
(1.891)\end{array}$ & $\begin{array}{l}15.37 \\
(2.320)\end{array}$ & $\begin{array}{c}17.99 \\
(3.000)\end{array}$ \\
\hline Microbial biomass C & $\begin{array}{c}383.29 \\
(10.191)\end{array}$ & $\begin{array}{c}419.05 \\
(67.566)\end{array}$ & $\begin{array}{c}478.40 \\
(48.382)\end{array}$ & $\begin{array}{c}562.41 \\
(78.768)\end{array}$ & $\begin{array}{c}313.18 \\
(30.331)\end{array}$ & $\begin{array}{c}669.42 \\
(70.026)\end{array}$ & $\begin{array}{c}636.97 \\
(55.306)\end{array}$ & $\begin{array}{c}512.19 \\
(43.310)\end{array}$ \\
\hline Microbial biomass $\mathrm{N}$ & $\begin{array}{c}76.05 \\
(3.911)\end{array}$ & $\begin{array}{c}126.34 \\
(29.361)\end{array}$ & $\begin{array}{c}110.68 \\
(10.260)\end{array}$ & $\begin{array}{c}129.79 \\
(17.990)\end{array}$ & $\begin{array}{c}34.83 \\
(2.141)\end{array}$ & $\begin{array}{c}81.41 \\
(10.015)\end{array}$ & $\begin{array}{c}111.86 \\
(14.610)\end{array}$ & $\begin{array}{c}111.75 \\
(10.840)\end{array}$ \\
\hline \multicolumn{9}{|l|}{ Shrubs removed } \\
\hline $\mathrm{NH}_{4}^{+}$ & $\begin{array}{c}1.65 \\
(0.129)\end{array}$ & $\begin{array}{c}4.16 \\
(0.705)\end{array}$ & $\begin{array}{c}5.54 \\
(1.005)\end{array}$ & $\begin{array}{c}2.36 \\
(0.597)\end{array}$ & $\begin{array}{c}4.14 \\
(0.922)\end{array}$ & $\begin{array}{c}7.47 \\
(2.216)\end{array}$ & $\begin{array}{c}5.99 \\
(0.968)\end{array}$ & $\begin{array}{c}9.74 \\
(1.621)\end{array}$ \\
\hline $\mathrm{NO}_{3}^{-}$ & $\begin{array}{c}6.17 \\
(3.030)\end{array}$ & $\begin{array}{l}12.17 \\
(1.758)\end{array}$ & $\begin{array}{l}48.34 \\
(8.452)\end{array}$ & $\begin{array}{c}29.23 \\
(3.544)\end{array}$ & $\begin{array}{c}37.57 \\
(4.122)\end{array}$ & $\begin{array}{l}37.31 \\
(5.062)\end{array}$ & $\begin{array}{c}25.28 \\
(4.342)\end{array}$ & $\begin{array}{c}31.03 \\
(8.097)\end{array}$ \\
\hline Dissolved inorganic $\mathrm{N}$ & $\begin{array}{c}7.82 \\
(2.926)\end{array}$ & $\begin{array}{c}16.33 \\
(1.582)\end{array}$ & $\begin{array}{c}53.88 \\
(8.719)\end{array}$ & $\begin{array}{c}31.59 \\
(3.487)\end{array}$ & $\begin{array}{c}41.71 \\
(3.790)\end{array}$ & $\begin{array}{c}44.79 \\
(3.756)\end{array}$ & $\begin{array}{c}31.27 \\
(3.616)\end{array}$ & $\begin{array}{c}40.77 \\
(6.775)\end{array}$ \\
\hline Dissolved organic C & $\begin{array}{c}70.43 \\
(5.918)\end{array}$ & $\begin{array}{c}193.51 \\
(17.037)\end{array}$ & $\begin{array}{c}194.97 \\
(24.658)\end{array}$ & $\begin{array}{c}132.78 \\
(14.093)\end{array}$ & $\begin{array}{c}171.65 \\
(20.256)\end{array}$ & $\begin{array}{c}270.49 \\
(32.709)\end{array}$ & $\begin{array}{c}230.67 \\
(19.635)\end{array}$ & $\begin{array}{c}226.26 \\
(26.497)\end{array}$ \\
\hline Dissolved organic $\mathrm{N}$ & $\begin{array}{c}7.08 \\
(0.815)\end{array}$ & $\begin{array}{c}12.31 \\
(3.106)\end{array}$ & $\begin{array}{c}30.11 \\
(9.345)\end{array}$ & $\begin{array}{c}15.97 \\
(2.677)\end{array}$ & $\begin{array}{c}23.35 \\
(3.007)\end{array}$ & $\begin{array}{c}16.95 \\
(3.156)\end{array}$ & $\begin{array}{c}12.07 \\
(1.599)\end{array}$ & $\begin{array}{c}25.50 \\
(4.473)\end{array}$ \\
\hline Microbial biomass C & $\begin{array}{c}318.74 \\
(101.260)\end{array}$ & $\begin{array}{c}395.72 \\
(76.994)\end{array}$ & $\begin{array}{c}452.45 \\
(38.384)\end{array}$ & $\begin{array}{c}555.85 \\
(71.089)\end{array}$ & $\begin{array}{c}314.70 \\
(24.727)\end{array}$ & $\begin{array}{c}565.72 \\
(62.638)\end{array}$ & $\begin{array}{c}569.15 \\
(59.225)\end{array}$ & $\begin{array}{c}429.76 \\
(41.880)\end{array}$ \\
\hline Microbial biomass N & $\begin{array}{c}58.12 \\
(24.566)\end{array}$ & $\begin{array}{l}100.15 \\
(19.403)\end{array}$ & $\begin{array}{l}106.96 \\
(9.734)\end{array}$ & $\begin{array}{c}124.25 \\
(14.072)\end{array}$ & $\begin{array}{c}37.76 \\
(4.771)\end{array}$ & $\begin{array}{c}62.66 \\
(6.215)\end{array}$ & $\begin{array}{c}97.57 \\
(12.704)\end{array}$ & $\begin{array}{c}97.82 \\
(9.377)\end{array}$ \\
\hline
\end{tabular}


Appendix 6. Inorganic nitrogen pools in chronosequence removals at each date. Year 0 plots were cut in Feb 2011. Year 1 plots were cut between Nov 2009 and Mar 2010. Year 2 plots were cut between Dec 2008 and Jan 2009. Values are means ( \pm SE) expressed as $\mu \mathrm{g}$ $\mathrm{N} \mathrm{g}^{-1}$ soil. In April 2011, all removals plots were sampled except H17 (Year 0; $\mathrm{n}=3$ ). No statistically significant differences $(p \leq 0.05$ ) were observed between chronosequence removals within a date.

\begin{tabular}{|c|c|c|c|c|c|c|c|c|c|}
\hline \multirow[b]{2}{*}{ Date } & \multicolumn{3}{|c|}{$\begin{array}{l}\text { Year } 0 \text { Chronosequence } \\
(\mathrm{n}=4)\end{array}$} & \multicolumn{3}{|c|}{$\begin{array}{l}\text { Year } 1 \text { Chronosequence } \\
\qquad(\mathrm{n}=5)\end{array}$} & \multicolumn{3}{|c|}{$\begin{array}{c}\text { Year } 2 \text { Chronosequence } \\
(\mathrm{n}=5)\end{array}$} \\
\hline & $\mathrm{NH}_{4}^{+}$ & $\mathrm{NO}_{3}^{-}$ & DIN & $\mathrm{NH}_{4}^{+}$ & $\mathrm{NO}_{3}^{-}$ & DIN & $\mathrm{NH}_{4}^{+}$ & $\mathrm{NO}_{3}^{-}$ & DIN \\
\hline Feb 2011 & $\begin{array}{c}1.65 \\
(0.112)\end{array}$ & $\begin{array}{c}6.17 \\
(2.624)\end{array}$ & $\begin{array}{c}7.82 \\
(2.534)\end{array}$ & ----- & ----- & ----- & ---- & ----- & ----- \\
\hline Apr 2011 & $\begin{array}{c}3.92 \\
(0.607)\end{array}$ & $\begin{array}{c}16.52 \\
(3.250)\end{array}$ & $\begin{array}{l}20.45 \\
(2.807)\end{array}$ & $\begin{array}{c}6.65 \\
(0.846)\end{array}$ & $\begin{array}{c}8.30 \\
(2.583)\end{array}$ & $\begin{array}{l}14.95 \\
(2.672)\end{array}$ & $\begin{array}{c}1.81 \\
(0.271)\end{array}$ & $\begin{array}{l}13.43 \\
(2.493)\end{array}$ & $\begin{array}{l}15.25 \\
(2.433)\end{array}$ \\
\hline May 2011 & $\begin{array}{c}6.67 \\
(3.080)\end{array}$ & $\begin{array}{c}44.06 \\
(18.517)\end{array}$ & $\begin{array}{c}50.73 \\
(19.008)\end{array}$ & $\begin{array}{c}5.40 \\
(1.376)\end{array}$ & $\begin{array}{l}54.09 \\
(9.672)\end{array}$ & $\begin{array}{c}59.49 \\
(10.953)\end{array}$ & $\begin{array}{c}4.78 \\
(1.095)\end{array}$ & $\begin{array}{c}4602 \\
(18.373)\end{array}$ & $\begin{array}{c}50.80 \\
(18.516)\end{array}$ \\
\hline Aug 2011 & $\begin{array}{c}1.94 \\
(0.463)\end{array}$ & $\begin{array}{l}24.30 \\
(4.763)\end{array}$ & $\begin{array}{c}26.24 \\
(4.730)\end{array}$ & $\begin{array}{c}1.07 \\
(0.222)\end{array}$ & $\begin{array}{l}36.50 \\
(7.387)\end{array}$ & $\begin{array}{l}37.57 \\
(7.568)\end{array}$ & $\begin{array}{c}3.98 \\
(1.400)\end{array}$ & $\begin{array}{c}25.91 \\
(5.035)\end{array}$ & $\begin{array}{c}29.90 \\
(4.955)\end{array}$ \\
\hline Oct 2011 & $\begin{array}{c}8.31 \\
(1.355)\end{array}$ & $\begin{array}{l}26.85 \\
(6.513)\end{array}$ & $\begin{array}{l}35.17 \\
(7.821)\end{array}$ & $\begin{array}{c}2.80 \\
(0.863)\end{array}$ & $\begin{array}{l}37.60 \\
(6.172)\end{array}$ & $\begin{array}{l}40.40 \\
(5.561)\end{array}$ & $\begin{array}{c}2.14 \\
(0.978)\end{array}$ & $\begin{array}{c}46.12 \\
(7.058)\end{array}$ & $\begin{array}{c}48.26 \\
(6.585)\end{array}$ \\
\hline Nov 2011 & $\begin{array}{c}8.23 \\
(5.132)\end{array}$ & $\begin{array}{c}42.43 \\
(13.199)\end{array}$ & $\begin{array}{c}50.66 \\
(10.550)\end{array}$ & $\begin{array}{c}8.31 \\
(4.661)\end{array}$ & $\begin{array}{l}34.37 \\
(8.641)\end{array}$ & $\begin{array}{l}42.67 \\
(5.169)\end{array}$ & $\begin{array}{c}6.04 \\
(2.519)\end{array}$ & $\begin{array}{l}36.16 \\
(6.7990\end{array}$ & $\begin{array}{c}42.20 \\
(5.020)\end{array}$ \\
\hline Feb 2012 & $\begin{array}{c}7.72 \\
(1.714)\end{array}$ & $\begin{array}{l}17.92 \\
(2.869)\end{array}$ & $\begin{array}{l}25.64 \\
(3.085)\end{array}$ & $\begin{array}{c}5.45 \\
(2.124)\end{array}$ & $\begin{array}{c}25.76 \\
(11.141)\end{array}$ & $\begin{array}{l}31.21 \\
(9.191)\end{array}$ & $\begin{array}{c}5.15 \\
(1.184)\end{array}$ & $\begin{array}{l}30.68 \\
(4.937)\end{array}$ & $\begin{array}{c}35.82 \\
(4.160)\end{array}$ \\
\hline Apr 2012 & $\begin{array}{c}8.54 \\
(2.954)\end{array}$ & $\begin{array}{c}23.69 \\
(16.198)\end{array}$ & $\begin{array}{c}32.24 \\
(13.645)\end{array}$ & $\begin{array}{c}7.44 \\
(3.075)\end{array}$ & $\begin{array}{c}50.92 \\
(15.508)\end{array}$ & $\begin{array}{c}58.37 \\
(12.704)\end{array}$ & $\begin{array}{c}12.98 \\
(2.231)\end{array}$ & $\begin{array}{c}17.00 \\
(6.312)\end{array}$ & $\begin{array}{c}29.99 \\
(4.862)\end{array}$ \\
\hline
\end{tabular}


Appendix 7. Organic nutrient pools in chronosequence removals at each date. Year 0 plots were cut in Feb 2011. Year 1 plots were cut between Nov 2009 and Mar 2010. Year 2 plots were cut between Dec 2008 and Jan 2009. Values are means ( \pm SE) expressed as $\mu$ g N $\mathrm{g}^{-1}$ soil. In April 2011, all removals plots were sampled except H17 (Year 0; $\mathrm{n}=3$ ). Different letters denote statistically significant differences $(p \leq 0.05)$ between chronosequence removals for a given nutrient pool within a date.

\begin{tabular}{|c|c|c|c|c|c|c|c|c|c|c|c|c|}
\hline \multirow[b]{2}{*}{ Date } & \multicolumn{4}{|c|}{$\begin{array}{l}\text { Year } 0 \text { Chronosequence } \\
\qquad(\mathrm{n}=4)\end{array}$} & \multicolumn{4}{|c|}{$\begin{array}{l}\text { Year } 1 \text { Chronosequence } \\
\qquad(\mathrm{n}=5)\end{array}$} & \multicolumn{4}{|c|}{$\begin{array}{l}\text { Year } 2 \text { Chronosequence } \\
\qquad(\mathrm{n}=5)\end{array}$} \\
\hline & DOC & DON & MB-C & MB-N & DOC & DON & MB-C & MB-N & DOC & DON & MB-C & MB-N \\
\hline $\begin{array}{l}\text { Feb } \\
2011\end{array}$ & $\begin{array}{c}70.43 \\
(5.125)\end{array}$ & $\begin{array}{c}7.08 \\
(0.706)\end{array}$ & $\begin{array}{c}318.74 \\
(87.694)\end{array}$ & $\begin{array}{c}58.12 \\
(21.274)\end{array}$ & ----- & ----- & ----- & ---- & ----- & ----- & ----- & ----- \\
\hline $\begin{array}{l}\text { Apr } \\
2011\end{array}$ & $\begin{array}{l}167.20 \\
(6.051)\end{array}$ & $\begin{array}{c}5.17 \\
(0.986)\end{array}$ & $\begin{array}{l}172.81^{\mathbf{b}} \\
(44.824)\end{array}$ & $\begin{array}{c}42.59^{\mathbf{b}} \\
(12.815)\end{array}$ & $\begin{array}{c}234.41 \\
(35.841)\end{array}$ & $\begin{array}{l}16.28 \\
(5.472)\end{array}$ & $\begin{array}{c}666.74^{\mathbf{a}} \\
(118.246)\end{array}$ & $\begin{array}{l}176.93^{\mathbf{a}} \\
(19.012)\end{array}$ & $\begin{array}{c}168.38 \\
(16.877)\end{array}$ & $\begin{array}{c}12.62 \\
(5.769)\end{array}$ & $\begin{array}{l}258.46^{\mathbf{b}} \\
(30.442)\end{array}$ & $\begin{array}{l}57.91^{\mathbf{b}} \\
(9.619)\end{array}$ \\
\hline $\begin{array}{l}\text { May } \\
2011\end{array}$ & $\begin{array}{l}150.85 \\
(30.897)\end{array}$ & $\begin{array}{c}46.32 \\
(31.764)\end{array}$ & $\begin{array}{c}477.21 \\
(66.437)\end{array}$ & $\begin{array}{c}105.25 \\
(16.780)\end{array}$ & $\begin{array}{c}232.58 \\
(29.550)\end{array}$ & $\begin{array}{c}23.14 \\
(4.556)\end{array}$ & $\begin{array}{c}470.81 \\
(82.974)\end{array}$ & $\begin{array}{c}124.50 \\
(19.225)\end{array}$ & $\begin{array}{c}192.66 \\
(57.815)\end{array}$ & $\begin{array}{l}24.12 \\
(9.746)\end{array}$ & $\begin{array}{c}414.27 \\
(57.471)\end{array}$ & $\begin{array}{c}90.78 \\
(13.442)\end{array}$ \\
\hline $\begin{array}{l}\text { Aug } \\
2011\end{array}$ & $\begin{array}{c}125.47 \\
(17.491)\end{array}$ & $\begin{array}{c}12.47 \\
(3.779)\end{array}$ & $\begin{array}{c}650.88 \\
(157.240)\end{array}$ & $\begin{array}{c}126.26 \\
(21.359)\end{array}$ & $\begin{array}{c}121.78 \\
(14.857)\end{array}$ & $\begin{array}{c}22.24 \\
(5.683)\end{array}$ & $\begin{array}{c}579.55 \\
(124.684)\end{array}$ & $\begin{array}{c}122.41 \\
(20.971)\end{array}$ & $\begin{array}{c}149.62 \\
(35.933)\end{array}$ & $\begin{array}{c}12.50 \\
(3.011)\end{array}$ & $\begin{array}{c}456.13 \\
(105.711)\end{array}$ & $\begin{array}{c}124.48 \\
(32.966)\end{array}$ \\
\hline $\begin{array}{l}\text { Oct } \\
2011\end{array}$ & $\begin{array}{c}175.32 \\
(54.932)\end{array}$ & $\begin{array}{c}18.12 \\
(5.629)\end{array}$ & $\begin{array}{c}276.25 \\
(35.067)\end{array}$ & $\begin{array}{c}29.92 \\
(6.463)\end{array}$ & $\begin{array}{c}183.52 \\
(10.652)\end{array}$ & $\begin{array}{c}20.71 \\
(4.782)\end{array}$ & $\begin{array}{c}339.26 \\
(56.511)\end{array}$ & $\begin{array}{l}46.48 \\
(8.779)\end{array}$ & $\begin{array}{c}156.85 \\
(41.439)\end{array}$ & $\begin{array}{c}30.19 \\
(4.634)\end{array}$ & $\begin{array}{c}320.89 \\
(34.303)\end{array}$ & $\begin{array}{c}35.31 \\
(8.496)\end{array}$ \\
\hline $\begin{array}{l}\text { Nov } \\
2011\end{array}$ & $\begin{array}{c}241.17 \\
(76.451)\end{array}$ & $\begin{array}{l}22.29 \\
(9.118)\end{array}$ & $\begin{array}{c}509.38 \\
(55.235)\end{array}$ & $\begin{array}{c}48.23 \\
(8.844)\end{array}$ & $\begin{array}{c}345.52 \\
(40.716)\end{array}$ & $\begin{array}{c}12.85 \\
(4.559)\end{array}$ & $\begin{array}{c}543.23 \\
(155.764)\end{array}$ & $\begin{array}{c}73.59 \\
(11.977)\end{array}$ & $\begin{array}{c}218.93 \\
(48.243)\end{array}$ & $\begin{array}{c}16.79 \\
(3.170)\end{array}$ & $\begin{array}{c}633.26 \\
(87.801)\end{array}$ & $\begin{array}{c}63.26 \\
(9.461)\end{array}$ \\
\hline $\begin{array}{l}\text { Feb } \\
2012\end{array}$ & $\begin{array}{c}233.08 \\
(45.027)\end{array}$ & $\begin{array}{c}8.39 \\
(2.088)\end{array}$ & $\begin{array}{c}465.89 \\
(120.444)\end{array}$ & $\begin{array}{c}97.46 \\
(22.757)\end{array}$ & $\begin{array}{c}241.91 \\
(24.523)\end{array}$ & $\begin{array}{l}17.69 \\
(2.032)\end{array}$ & $\begin{array}{c}673.13 \\
(46.043)\end{array}$ & $\begin{array}{c}112.06 \\
(21.232)\end{array}$ & $\begin{array}{c}217.50 \\
(40.179)\end{array}$ & $\begin{array}{c}9.39 \\
(2.033)\end{array}$ & $\begin{array}{c}547.78 \\
(127.067)\end{array}$ & $\begin{array}{c}83.17 \\
(24.550)\end{array}$ \\
\hline $\begin{array}{c}\text { Apr } \\
2012\end{array}$ & $\begin{array}{c}162.74 \\
(19.063)\end{array}$ & $\begin{array}{c}22.64 \\
(8.374)\end{array}$ & $\begin{array}{c}370.13 \\
(14.875)\end{array}$ & $\begin{array}{c}69.54 \\
(9.846)\end{array}$ & $\begin{array}{c}285.73 \\
(61.655)\end{array}$ & $\begin{array}{c}37.58 \\
(8.219)\end{array}$ & $\begin{array}{c}532.72 \\
(33.108)\end{array}$ & $\begin{array}{l}124.17 \\
(6.628)\end{array}$ & $\begin{array}{c}217.60 \\
(25.688)\end{array}$ & $\begin{array}{c}15.70 \\
(3.211)\end{array}$ & $\begin{array}{c}374.50 \\
(102.990)\end{array}$ & $\begin{array}{c}94.10 \\
(19.002)\end{array}$ \\
\hline
\end{tabular}


Appendix 8. The strongest overall multiple regression model for nutrient pools in shrub present plots. Parentheses enclose standard errors for the intercept and regression coefficients. Winter 2011 is not included due to the low number of plots sampled $(\mathrm{n}=3)$.

\begin{tabular}{|c|c|c|c|c|c|c|c|c|c|c|c|}
\hline & & \multirow[b]{2}{*}{ Intercept } & \multicolumn{7}{|c|}{ Regression Coefficients } & \multirow[b]{2}{*}{ Adj. $R^{2}$} & \multirow[b]{2}{*}{ p-value } \\
\hline & & & HS Stem & Tree BA & $\%$ Herb & $\%$ Bare Soil & Northness & Eastness & Soil $\mathrm{H}_{2} \mathrm{O}$ & & \\
\hline \multirow{7}{*}{ 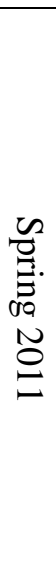 } & $\mathrm{NH}_{4}$ & $\begin{array}{c}2.17 \\
(1.419)\end{array}$ & & & $\begin{array}{c}-1.62 \\
(1.125)\end{array}$ & & & $\begin{array}{c}-1.20 \\
(0.528)\end{array}$ & $\begin{array}{c}6.62 \\
(2.783)\end{array}$ & 0.1202 & 0.0243 \\
\hline & $\mathrm{NO}_{3}$ & $\begin{array}{l}-38.81 \\
(9.925)\end{array}$ & & $\begin{array}{c}0.56 \\
(0.206)\end{array}$ & $\begin{array}{c}15.48 \\
(6.817)\end{array}$ & & & & $\begin{array}{c}110.05 \\
(17.319)\end{array}$ & 048 & 0.0001 \\
\hline & DIN & $\begin{array}{c}-36.39 \\
(10.375)\end{array}$ & & $\begin{array}{c}0.55 \\
(0.215)\end{array}$ & $\begin{array}{c}14.58 \\
(7.126)\end{array}$ & & & & $\begin{array}{c}116.03 \\
(18.104)\end{array}$ & 0.48 & 0.0001 \\
\hline & DOC & $\begin{array}{c}72.90 \\
(34.600)\end{array}$ & & $\begin{array}{c}1.67 \\
(0.740)\end{array}$ & $\begin{array}{c}45.56 \\
(24.424)\end{array}$ & $\begin{array}{c}141.92 \\
(54.247)\end{array}$ & & & & 0.19 & 0.0041 \\
\hline & DON & $\begin{array}{c}-18.24 \\
(11.127)\end{array}$ & & $\begin{array}{c}0.40 \\
(0.233)\end{array}$ & & & & & $\begin{array}{c}60.19 \\
(19.955)\end{array}$ & 0.15 & 0.0054 \\
\hline & MB-C & $\begin{array}{c}118.45 \\
(91.325)\end{array}$ & & & & $\begin{array}{c}579.69 \\
(159.070)\end{array}$ & & & & 0.19 & 0.0006 \\
\hline & MB-N & $\begin{array}{c}32.83 \\
(30.026)\end{array}$ & & & & $\begin{array}{c}141.95 \\
(52.300)\end{array}$ & & & & 0.11 & 0.0090 \\
\hline \multirow{7}{*}{ 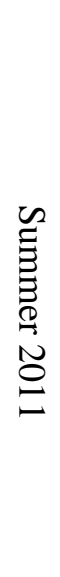 } & $\mathrm{NH}_{4}$ & $\begin{array}{c}6.27 \\
(2.978)\end{array}$ & & $\begin{array}{c}0.061 \\
(0.0326)\end{array}$ & & & & & $\begin{array}{c}-12.56 \\
(7.414)\end{array}$ & 0.11 & 0.094 \\
\hline & $\mathrm{NO}_{3}$ & $\begin{array}{c}32.74 \\
(2.623)\end{array}$ & & & & & $\begin{array}{c}-6.61 \\
(4.471)\end{array}$ & & & 0.04 & 0.15 \\
\hline & DIN & $\begin{array}{c}34.98 \\
(2.663)\end{array}$ & & & & & $\begin{array}{c}-7.04 \\
(4.539)\end{array}$ & & & 0.05 & 0.13 \\
\hline & DOC & $\begin{array}{c}122.63 \\
(18.837)\end{array}$ & & $\begin{array}{c}1.00 \\
(0.877)\end{array}$ & & & & & & 0.01 & 0.26 \\
\hline & DON & $\begin{array}{c}37.13 \\
(11.372)\end{array}$ & & $\begin{array}{c}-0.27 \\
(0.184)\end{array}$ & & $\begin{array}{c}-18.18 \\
(12.614)\end{array}$ & $\begin{array}{l}-11.59 \\
(4.751)\end{array}$ & $\begin{array}{c}4.48 \\
(2.753)\end{array}$ & & 0.10 & 0.18 \\
\hline & MB-C & $\begin{array}{c}-941.87 \\
(380.390)\end{array}$ & & & & $\begin{array}{c}564.89 \\
(209.969)\end{array}$ & & & $\begin{array}{c}2590.16 \\
(794.231)\end{array}$ & 0.35 & 0.0019 \\
\hline & MB-N & $\begin{array}{l}-261.07 \\
(68.329)\end{array}$ & & & & $\begin{array}{c}68.24 \\
(37.717)\end{array}$ & & & $\begin{array}{c}818.09 \\
(142.667)\end{array}$ & 0.39 & 0.0010 \\
\hline
\end{tabular}


Appendix 8. cont.

Regression Coefficients

\begin{tabular}{|c|c|c|c|c|c|c|c|c|c|c|c|}
\hline & & \multirow[b]{2}{*}{ Intercept } & \multicolumn{7}{|c|}{ Regression Coefficients } & \multirow[b]{2}{*}{ Adj. $R^{2}$} & \multirow[b]{2}{*}{ p-value } \\
\hline & & & HS Stem & Tree BA & $\%$ Herb & $\%$ Bare Soil & Northness & Eastness & Soil $\mathrm{H}_{2} \mathrm{O}$ & & \\
\hline \multirow{7}{*}{$\begin{array}{l}\stackrel{T}{\mathscr{N}} \\
\stackrel{N}{0} \\
\stackrel{\varrho}{=}\end{array}$} & $\mathrm{NH}_{4}$ & $\begin{array}{c}5.62 \\
(0.893)\end{array}$ & & & $\begin{array}{c}-5.92 \\
(4.593)\end{array}$ & & $\begin{array}{c}-2.59 \\
(1.352)\end{array}$ & & & 0.059 & 0.0749 \\
\hline & $\mathrm{NO}_{3}$ & $\begin{array}{c}14.03 \\
(15.030)\end{array}$ & & & & $\begin{array}{c}14.64 \\
(12.328)\end{array}$ & & $\begin{array}{c}4.94 \\
(2.911)\end{array}$ & $\begin{array}{c}63.72 \\
(35.897)\end{array}$ & 0.054 & 0.12 \\
\hline & DIN & $\begin{array}{c}32.00 \\
(7.440)\end{array}$ & & & & & $\begin{array}{c}-5.55 \\
(3.367)\end{array}$ & $\begin{array}{c}5.70 \\
(2.543)\end{array}$ & $\begin{array}{c}36.91 \\
(20.715)\end{array}$ & 0.095 & 0.043 \\
\hline & DOC & $\begin{array}{c}11.77 \\
(58.501)\end{array}$ & & & & & $\begin{array}{c}-44.86 \\
(26.477)\end{array}$ & $\begin{array}{c}42.73 \\
(19.998)\end{array}$ & $\begin{array}{c}640.89 \\
(162.881)\end{array}$ & 0.24 & 0.0006 \\
\hline & DON & $\begin{array}{c}15.70 \\
(3.516)\end{array}$ & & $\begin{array}{c}0.15 \\
(0.141)\end{array}$ & & $\begin{array}{c}12.20 \\
(6.284)\end{array}$ & & $\begin{array}{c}3.23 \\
(2.143)\end{array}$ & & 0.072 & 0.077 \\
\hline & $\mathrm{MB}-\mathrm{C}$ & $\begin{array}{c}327.07 \\
(166.587)\end{array}$ & & & & $\begin{array}{c}-369.21 \\
(136.634)\end{array}$ & & $\begin{array}{c}41.20 \\
(32.261)\end{array}$ & $\begin{array}{c}666.94 \\
(397.866)\end{array}$ & 0.38 & 0.0001 \\
\hline & MB-N & $\begin{array}{c}6.69 \\
(20.177)\end{array}$ & & & & $\begin{array}{c}-25.60 \\
(16.604)\end{array}$ & $\begin{array}{c}-9.69 \\
(5.478)\end{array}$ & $\begin{array}{c}6.85 \\
(4.125)\end{array}$ & $\begin{array}{c}153.49 \\
(48.191)\end{array}$ & 0.42 & 0.0001 \\
\hline \multirow{7}{*}{ 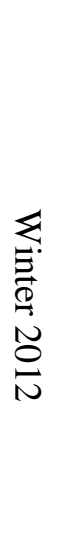 } & $\mathrm{NH}_{4}$ & $\begin{array}{c}11.74 \\
(3.204)\end{array}$ & & & & & & & $\begin{array}{l}-12.68 \\
(7.646)\end{array}$ & 0.061 & 0.11 \\
\hline & $\mathrm{NO}_{3}$ & $\begin{array}{c}-8.58 \\
(13.761)\end{array}$ & & & & & & & $\begin{array}{c}82.00 \\
(32.843)\end{array}$ & 0.16 & 0.0192 \\
\hline & DIN & $\begin{array}{c}3.16 \\
(11.882)\end{array}$ & & & & & & & $\begin{array}{c}69.32 \\
(28.357)\end{array}$ & 0.16 & 0.022 \\
\hline & DOC & $\begin{array}{c}94.66 \\
(58.970)\end{array}$ & & $\begin{array}{c}1.56 \\
(1.133)\end{array}$ & & $\begin{array}{c}261.42 \\
(110.027)\end{array}$ & & & & 0.18 & 0.0328 \\
\hline & DON & $\begin{array}{c}3.62 \\
(5.615)\end{array}$ & & $\begin{array}{l}-0.13 \\
(0.108)\end{array}$ & & $\begin{array}{c}25.18 \\
(10.476)\end{array}$ & & & & 0.15 & 0.047 \\
\hline & MB-C & $\begin{array}{c}-350.97 \\
(226.779)\end{array}$ & & & & $\begin{array}{c}506.28 \\
(256.659)\end{array}$ & & & $\begin{array}{c}1716.92 \\
(370.368)\end{array}$ & 0.42 & 0.0004 \\
\hline & MB-N & $\begin{array}{l}-167.95 \\
(44.253)\end{array}$ & & & & $\begin{array}{c}157.19 \\
(50.083)\end{array}$ & & & $\begin{array}{c}475.64 \\
(72.272)\end{array}$ & 0.61 & 0.0001 \\
\hline
\end{tabular}


Appendix 8. cont.

Regression Coefficients

\begin{tabular}{|c|c|c|c|c|c|c|c|c|c|c|c|}
\hline & & \multirow[b]{2}{*}{ Intercept } & \multicolumn{7}{|c|}{ Regression Coefficients } & \multirow[b]{2}{*}{ Adj. $R^{2}$} & \multirow[b]{2}{*}{ p-value } \\
\hline & & & HS Stem & Tree BA & $\%$ Herb & $\%$ Bare Soil & Northness & Eastness & Soil $\mathrm{H}_{2} \mathrm{O}$ & & \\
\hline \multirow{7}{*}{ 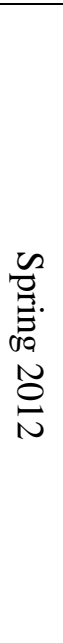 } & $\mathrm{NH}_{4}$ & $\begin{array}{c}9.30 \\
(2.058)\end{array}$ & & $\begin{array}{c}0.12 \\
(0.0932)\end{array}$ & & & & & & 0.023 & 0.21 \\
\hline & $\mathrm{NO}_{3}$ & $\begin{array}{c}-12.42 \\
(23.010)\end{array}$ & & & & $\begin{array}{c}62.06 \\
(37.508)\end{array}$ & & & & 0.061 & 0.11 \\
\hline & DIN & $\begin{array}{c}2.73 \\
(18.687)\end{array}$ & & & & $\begin{array}{c}55.97 \\
(30.461)\end{array}$ & & & & 0.081 & 0.0776 \\
\hline & DOC & $\begin{array}{c}-206.18 \\
(141.729 \\
)\end{array}$ & & & & $\begin{array}{c}423.83 \\
(181.997)\end{array}$ & $\begin{array}{c}52.43 \\
(37.774)\end{array}$ & & $\begin{array}{c}665.14 \\
(228.610)\end{array}$ & 0.25 & 0.019 \\
\hline & DON & $\begin{array}{c}-3.22 \\
(11.978)\end{array}$ & $\begin{array}{c}-0.00040 \\
(0.000229)\end{array}$ & & & $\begin{array}{c}47.25 \\
(19.169)\end{array}$ & & & & 0.22 & 0.018 \\
\hline & MB-C & $\begin{array}{c}-42.37 \\
(136.580\end{array}$ & $\begin{array}{c}0.0068 \\
(0.00255)\end{array}$ & $\begin{array}{c}3.45 \\
(2.222)\end{array}$ & $\begin{array}{c}129.92 \\
(64.511)\end{array}$ & $\begin{array}{c}559.44 \\
(198.129)\end{array}$ & & & & 0.33 & 0.0092 \\
\hline & MB-N & $\begin{array}{c}-20.54 \\
(30.082)\end{array}$ & $\begin{array}{c}0.0015 \\
(0.000562)\end{array}$ & $\begin{array}{c}1.28 \\
(0.489)\end{array}$ & $\begin{array}{c}42.30 \\
(14.208)\end{array}$ & $\begin{array}{c}117.68 \\
(43.638)\end{array}$ & & & & 0.41 & 0.0026 \\
\hline
\end{tabular}


Appendix 9. Repeated measures analysis of variance results for herb cover data. Chronosequence, sampling date, and their interaction served as fixed factors in the model. The degrees of freedom are listed for each F statistic. No significant differences were found between different chronosequences at any date.

\begin{tabular}{|c|c|c|c|c|c|c|}
\hline & \multicolumn{2}{|c|}{ Chronosequence } & \multicolumn{2}{|c|}{ Date } & \multicolumn{2}{|c|}{ Chronosequence x Date } \\
\hline & $\mathrm{F}_{2,11}$ & $\mathrm{P}$ & $\mathrm{F}_{6,65}$ & $\mathrm{P}$ & $F_{12,65}$ & $\mathrm{P}$ \\
\hline Herb Cover & 3.15 & 0.082 & 13.57 & $<0.0001$ & 1.77 & 0.072 \\
\hline
\end{tabular}


Appendix 10. Changes over time in herb cover for each of the chronosequence removals. Shrub removal plots were categorized into Year 0 (cut in Feb 2011), Year 1 (cut between Nov 2009 and Mar 2010), and Year 2 (cut between Dec 2008 and Jan 2009) in the chronosequence. Points are means $( \pm$ SE) at each sample date. Significant differences between chronosequences within any particular date are marked with an asterisk $(\mathrm{p} \leq 0.05)$. Multiple comparisons were correct for using the false discovery rate.

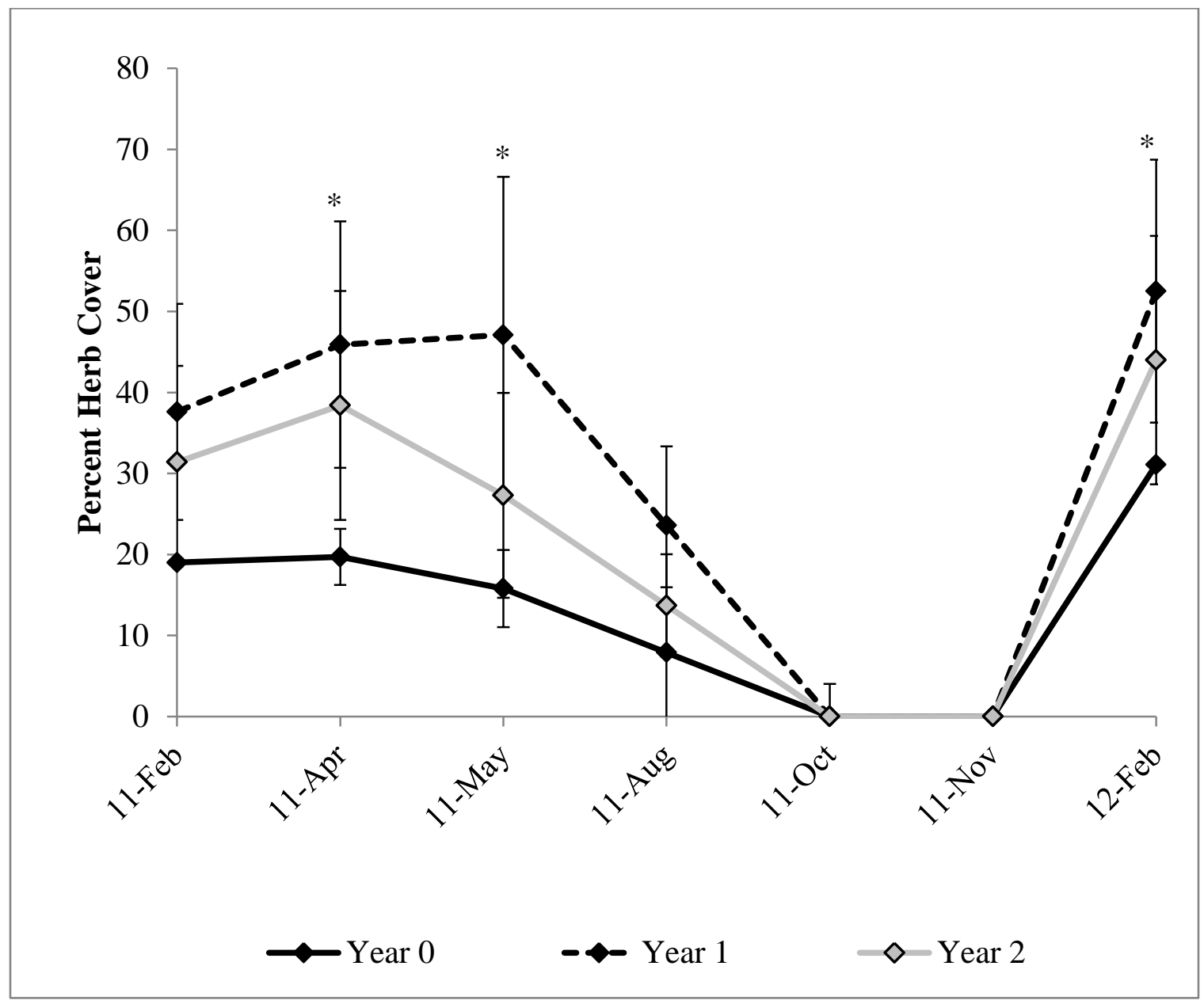


Appendix 11. Correlation matrix for mean total earthworm biomass (TWB), ammonium $\left(\mathrm{NH}_{4}\right)$, nitrate $\left(\mathrm{NO}_{3}\right)$, dissolved inorganic nitrogen (DIN), dissolved organic carbon (DOC), dissolved organic nitrogen (DON), microbial biomass carbon (MB-C), and microbial biomass nitrogen (MB-N) in April 2012.

\begin{tabular}{|c|c|c|c|c|c|c|c|c|}
\hline \multicolumn{9}{|c|}{$\begin{array}{l}\text { Pearson Correlation Coefficients } \\
\qquad \mathrm{N}=20\end{array}$} \\
\hline & TWB & $\mathrm{NH}_{4}^{+}$ & $\mathrm{NO}_{3}^{-}$ & DIN & DOC & DON & MB-C & MB-N \\
\hline TWB & 1.00000 & 0.51330 & -0.55113 & -0.53887 & 0.04125 & -0.43246 & -0.07321 & -0.07681 \\
\hline $\mathrm{NH}_{4}^{+}$ & & 1.00000 & -0.88533 & -0.81521 & 0.50257 & -0.59835 & 0.27623 & 0.32745 \\
\hline $\mathrm{NO}_{3}^{-}$ & & & 1.00000 & 0.99102 & -0.20601 & 0.74396 & -0.00109 & -0.06222 \\
\hline DIN & & & & 1.00000 & -0.11209 & 0.75462 & 0.07809 & 0.01666 \\
\hline DOC & & & & & 1.00000 & -0.16634 & 0.68304 & 0.73329 \\
\hline DON & & & & & & 1.00000 & 0.22061 & 0.10274 \\
\hline MB-C & & & & & & & 1.00000 & 0.91171 \\
\hline MB-N & & & & & & & & 1.00000 \\
\hline
\end{tabular}




\section{CURRICULUM VITAE \\ ROBERT PRESTON PIPAL}

775 Theodore Burnett $\mathrm{Ct}$, Apt 1

Louisville, KY 40217

preston.pipal@louisville.edu

(502) 303-4838

\section{EDUCATION}

2014 Ph.D., Biology, University of Louisville, Louisville, KY

Dissertation Title: Earthworm, microbial biomass, and leaf litter decay responses after invasive shrub removal from urban woodlands.

2007 B.S., Biology, University of Louisville, Louisville, KY

\section{TEACHING EXPERIENCE}

University of Louisville

Human Anatomy and Physiology Lab TA, 15 semesters, Aug 2009 - Dec 2014

- 25 health science undergraduates

- Created and presented lectures, graded coursework, and held office hours.

Introduction to Biological Systems Lab

TA, 1 semester, June 2010 - July 2010

- 25 undergraduate non-science majors.

- Presented lectures, created quizzes and exams, graded coursework

\section{SCHOLARSHIPS, GRANTS, AND AWARDS}

2014 William H. Clay Memorial Scholarship, University of Louisville.

2014 Faculty Favorite Teaching Award, University of Louisville.

2012 Best Research Presentation, University of Louisville.

2012 Faculty Favorite Teaching Award, University of Louisville.

2010 Woody Boebinger Scholarship, Kentucky Society of Natural History.

2007 Provost's Hallmark Scholarship, University of Louisville. 


\section{$\underline{\text { TEACHING INTERESTS }}$}

Human anatomy and physiology, general biology, ecology, science education and literacy

\section{RESEARCH EXPERIENCE}

2011-2014 Doctoral Research, Dept. of Biology, University of Louisville

Research advisor: Dr. Margaret Carreiro

- Examined the effects of invasive honeysuckle shrubs on the temporal dynamics of earthworms, soil microbial biomass, and leaf litter decay responses.

2008-2010 Research Assistant, Dept. of Biology, University of Louisville Supervisor: Dr. Margaret Carreiro

- Assisted in collecting data on herbaceous/tree species and soil erosion in an urban woodland invaded by exotic shrub honeysuckle

\section{$\underline{\text { PRESENTATIONS }}$}

2014 Pipal RP, Carreiro MM. Earthworm and macroinvertebrate activity responses after removal of invasive shrub honeysuckle from an urban woodland park. 41st Annual Natural Areas Conference. Dayton, Ohio. Research Talk.

2013 Pipal RP, Carreiro MM. Effects of exotic shrub honeysuckle on exotic earthworm populations and decomposer macroinvertebrate activity in an urban forest. Ohio Invasive Plants Council 2013 Research Conference. Columbus, Ohio. Poster.

2013

Pipal RP, Carreiro MM. Earthworm and macroinvertebrate activity responses after invasive shrub removal from an urban woodland park. Kentucky Academy of Sciences Annual Meeting. Morehead, Kentucky. Poster.

\section{$\underline{\text { PEER REVIEWED PUBLICATIONS }}$}

Pipal RP, Weintraub MN, Carreiro MM (2014) Seasonal soil nitrogen dynamics of a three year chronosequence in urban forests with and without Lonicera maackii. In progress 
Pipal RP, Carreiro MM (2014) Earthworm and macroinvertebrate responses after removal of invasive shrub honeysuckle from an urban woodland park. In progress

Carreiro MM, Pipal RP (2014) Leaf litter decay responses and nitrogen release patterns in an urban woodland invaded by exotic honeysuckle shrubs: The effects of litter mixing and soil macroinvertebrates. In progress

\section{PROFESSIONAL ASSOCIATIONS}

Kentucky Academy of Sciences

Ecological Society of America 